\title{
New Staphylinidae (Coleoptera) records with new collection data from New Brunswick and an addition to the fauna of Quebec: Staphylininae
}

\author{
Reginald P. Webster', Aleš Smetana², Jon D. Sweeney', Ian DeMerchant' \\ I Natural Resources Canada, Canadian Forest Service - Atlantic Forestry Centre, 1350 Regent St., P.O. Box \\ 4000, Fredericton, NB, Canada E3B $5 P 72$ Agriculture and Agri-Food Canada, Biodiversity, Central Experi- \\ mental Farm, K. W. Neatby Bldg., Ottawa, ON K1A OC6
}

Corresponding author: Reginald P. Webster (reginaldwebster@rogers.com)

Academic editor: J. Klimaszewski | Received 30 October 2011 | Accepted 20 January 2012 | Published 26 April 2012

Citation: Webster RP, Smetana A, Sweeney JD, DeMerchant I (2012) New Staphylinidae (Coleoptera) records with new collection data from New Brunswick and an addition to the fauna of Quebec: Staphylininae. In: Klimaszewski J, Anderson R (Eds) Biosystematics and Ecology of Canadian Staphylinidae (Coleoptera) II. ZooKeys 186: 293-348. doi: $10.3897 /$ zookeys.186.2469

\begin{abstract}
Forty-four species of Staphylininae are newly reported from New Brunswick, bringing the total number of species known from the province to 126. Quedius criddlei (Casey) is reported for the first time from Quebec. Bisnius cephalotes (Gravenhorst) is removed from the faunal list of New Brunswick due to a lack of supporting voucher specimens. Additional locality data are presented for seven species either recently recorded from the province or with few previous records and little habitat data. We provide the first documented records of Atrecus americanus (Casey), Quedius erythrogaster Mannerheim, Quedius labradorensis labradorensis Smetana, Quedius plagiatus (Mannerheim), and Neobisnius terminalis (LeConte) from New Brunswick. Collection and habitat data are presented and discussed for all species.
\end{abstract}

\section{Keywords}

Staphylinidae, Staphylininae, new records, Canada, New Brunswick, United States, Maine

\section{Introduction}

Intensive collecting of rove beetles (family Staphylinidae) in New Brunswick by the first author since 2003 has yielded many new provincial and national records. Addi-

Copyright Her Majesty the Queen in Right of Canada. This is an open access article distributed under the terms of the Creative Commons Attribution License 3.0 (CC-BY), which permits unrestricted use, distribution, and reproduction in any medium, provided the original author and source are credited. 
tional records were obtained from by-catch samples during a study to develop a general attractant for detecting invasive species of Cerambycidae. These records are being published in a series of papers, each focusing on one or more subfamilies of Staphylinidae and other families of Coleoptera. This paper covers the subfamily Staphylininae.

This subfamily is fairly well known taxonomically in Canada and North America, thanks to various revisions. The genera Erichsonius and Neobisnius were revised by Frank $(1975,1981)$, respectively. The Xantholinini were revised by Smetana (1982, 1988), the Quediina by Smetana (1965, 1971a, 1971b, 1973, 1976, 1978, 1981, 1990), the Philonthina by Smetana (1995), and the Staphylinina by Brunke et al. (2011). As a result of these revisions, our knowledge of the distribution of these species in Canada was also greatly increased.

Adults of Staphylininae live in a wide variety of habitats. Many species live in and near wetlands, including river and brook margins, lakeshores, vernal pool and pond margins, bogs, marshes, sea beaches, and various synanthropic situations (Smetana 1971a, 1982, 1995). Depending on species, adults usually occur in leaf litter, sphagnum moss, and other kinds of debris in these wetland habitats, but some species are highly hygrophilic and occur in floating mats of moss or vegetation (Smetana 1971a, 1982 , 1995). Other species are associated with decaying organic materials, including compost, decaying mushrooms, animal droppings, and carcasses. Some species are regular inhabitants of bird and mammal nests. Philonthus janus Smetana, P. couleensis Hatch, and Quedius campbelli Smetana are commonly found in North American beaver (Castor canadensis Kuhl) lodges and muskrat (Ondatra zibethicus (L.)) nests, but these associations are not strict, and these species can also be found in adjacent wetland habitats (Smetana 1995). However, a few species such as Heterothops marmotae Smetana and Bisnius lautus (Casey) have much stronger associations (Smetana 1971b, 1995). These species live in underground burrows of rodents and are rarely found in other habitats. Most species are probably general predators (Smetana 1995), although additional research is required to elucidate the biology of most members of this subfamily.

Campbell and Davies (1991) reported 27 species of Staphylininae for New Brunswick. The number of species recorded from the province was increased to 77 species as a result of revisions by Smetana (1995), and new additions to the fauna by Klimaszewski et al. (2005), Majka and Smetana (2007), Majka and Klimaszewski (2008a, b), Majka et al. (2009), Majka and Brown (2010), and Smetana and Webster (2011). Majka et al. (2011) reported Atrecus americanus (Casey), Quedius erythrogaster Mannerheim, Quedius labradorensis labradorensis Smetana, Quedius plagiatus (Mannerheim), and Neobisnius terminalis (LeConte) as occurring in New Brunswick but did not provide any supporting references or data for the records. Here, we report an additional 44 species of Staphylininae for New Brunswick, bringing the total number of species known for the province to 126 (Table 1). 
Table I. Species of Staphylininae (Staphylinidae) recorded from New Brunswick, Canada.

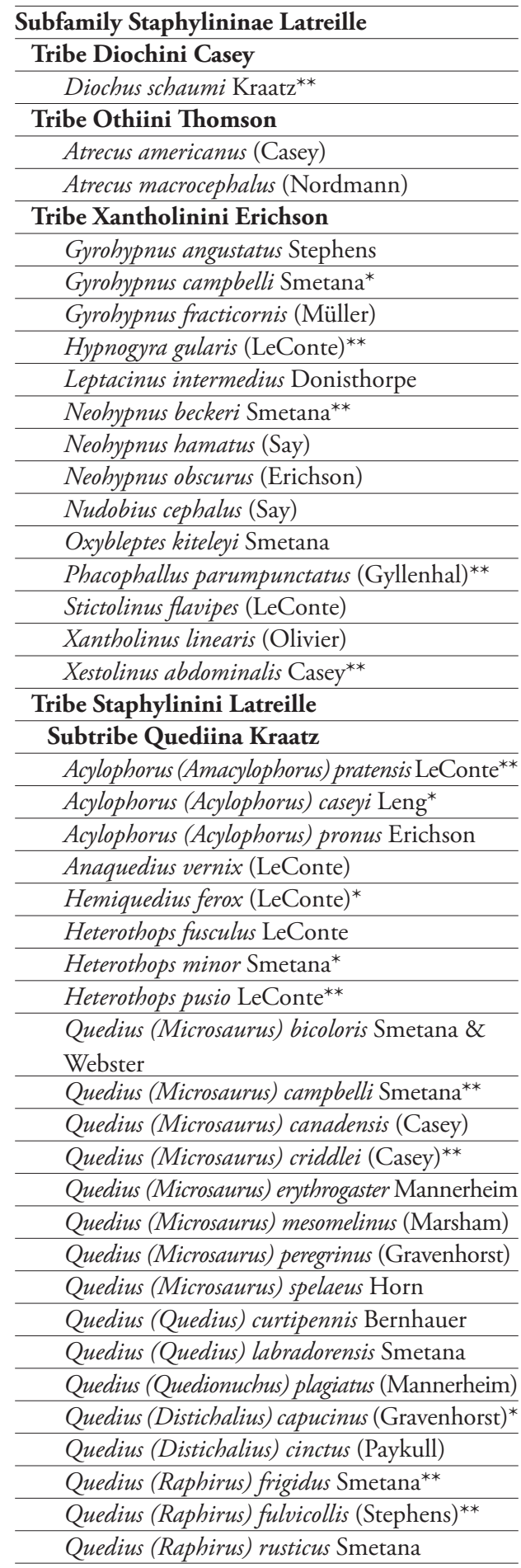

\begin{tabular}{|c|}
\hline Quedius (Raphirus) simulator Smetana** \\
\hline Subtribe Staphylinina Latreille \\
\hline Creophilus maxillosus (Linnaeus) \\
\hline Dinothenarus badipes LeConte \\
\hline Dinothenarus capitatus (Bland) \\
\hline Ontholestes cingulatus (Gravenhorst) \\
\hline Platydracus cinnamopterus Gravenhorst \\
\hline Platydracus cupripennis (Melsheimer) \\
\hline Platydracus fossator (Gravenhorst) \\
\hline Platydracus viridanus (Horn) \\
\hline Staphylinus ornaticauda LeConte* \\
\hline Tasgius ater (Gravenhorst) \\
\hline Tasgius melanarius (Heer) \\
\hline Subtribe Xanthopygina Sharp \\
\hline Tympanophorus puncticollis Erichson \\
\hline Subtribe Philonthina Kirby \\
\hline Bisnius blandus (Gravenhorst) \\
\hline Bisnius cephalicus (Casey) ${ }^{* *}$ \\
\hline Bisnius palmi (Smetana)* \\
\hline Bisnius quediinus (Horn) ${ }^{* *}$ \\
\hline Bisnius siegwaldii (Mannerhiem) \\
\hline Bisnius sordidus (Gravenhorst) \\
\hline Cafius bistriatus Erichson \\
\hline Erichsonius alumnus Frank** \\
\hline Erichsonius inutilis (Horn) $)^{* *}$ \\
\hline Erichsonius nanus (Horn) \\
\hline Erichsonius parcus (Horn) $)^{* *}$ \\
\hline Erichsonius patella (Horn)* \\
\hline Erichsonius pusio (Horn) $)^{* *}$ \\
\hline Erichsonius rosellus Frank ${ }^{* *}$ \\
\hline Gabrius appendiculatus Sharp \\
\hline Gabrius astutoides (A. Strand) \\
\hline Gabrius brevipennis (Horn) \\
\hline Gabrius fallaciosus (Horn)** \\
\hline Gabrius microphthalmus (Horn) \\
\hline Gabrius picipennis (Mäklin) \\
\hline Gabrius ulpius Smetana* \\
\hline Hesperus apicialis Say ${ }^{* *}$ \\
\hline Laetulonthus laetulus (Say) ${ }^{* *}$ \\
\hline Neobisnius jucundus (Horn)** \\
\hline Neobisnius lathrobioides (Baudi)** \\
\hline Neobisnius sobrinus (Erichson) \\
\hline Neobisnius terminalis (LeConte) \\
\hline Neobisnius villosulus (Stephens) \\
\hline Philonthus aequalis Horn** \\
\hline Philonthus boreas Smetana** \\
\hline Philonthus caeruleipennis (Mannerheim) \\
\hline Philonthus carbonarius (Gravenhorst) \\
\hline
\end{tabular}




\begin{tabular}{l}
\hline Philonthus cognatus Stephens \\
\hline Philonthus concinnus (Gravenhorst) \\
\hline Philonthus couleensis Hatch \\
\hline Philonthus cruentatus (Gmelini) \\
\hline Philonthus debilis (Gravenhorst) \\
\hline Philonthus discoideus (Gravenhorst) \\
\hline Philonthus flavibasis Casey* \\
\hline Philonthus flumineus Casey \\
\hline Philonthus furvus Nordman \\
\hline Philonthus fusiformis Melsheimer \\
\hline Philonthus gracilior Casey \\
\hline Philonthus hepaticus Erichson \\
\hline Philonthus hudsonicus Horn \\
\hline Philonthus janus Smetana \\
\hline Philonthus jurgans Tottenham \\
\hline Philonthus lindrothi Smetana \\
\hline Philonthus lomatus Erichson \\
\hline Philonthus monaeses Smetana \\
\hline Philonthus neonatus Smetana* \\
\hline Philonthus opacipennis Notman \\
\hline
\end{tabular}

\begin{tabular}{l}
\hline Philonthus palliatus (Gravenhorst) \\
\hline Philonthus politus (Linnaeus) \\
\hline Philonthus pseudolus Smetana** \\
\hline Philonthus quadricollis Horn \\
\hline Philonthus rectangulus Sharp \\
\hline Philonthus schwarzi Horn \\
\hline Philonthus sericans (Gravenhorst) \\
\hline Philonthus sericinus Horn** \\
\hline Philonthus sessor Smetana \\
\hline Philonthus sphagnorum Smetana \\
\hline Philonthus spiniformis Hatch \\
\hline Philonthus stictus Hausen \\
\hline Philonthus subvirescens Thomson \\
\hline Philonthus thoracicus (Gravenhorst) \\
\hline Philonthus umbratilis (Gravenhorst) \\
\hline Philonthus umbrinoides Smetana* \\
\hline Philonthus validus Casey \\
\hline Philonthus varians (Paykull) \\
\hline Philonthus varro Smetana \\
\hline Philonthus vulgatus Casey* \\
\hline
\end{tabular}

Notes: ${ }^{*}$ New to province; ${ }^{* *}$ New to Maritime provinces

\section{Methods and conventions}

The following records are based in part on specimens collected as part of a general survey by the first author to document the Coleoptera fauna of New Brunswick. Additional provincial records were obtained from specimens contained in the collection at Natural Resources Canada's Atlantic Forestry Centre in Fredericton, New Brunswick.

\section{Collection methods}

Various collection methods were employed to collect the Staphylininae reported in this study. Details are outlined in Campbell (1973) and Webster et al. (2009, Appendix). Many specimens were also collected as by-catch in Lindgren 12-funnel traps (ConTech Inc., Delta, BC) baited with various attractants as part of a study to develop a general attractant for detecting invasive species of Cerambycidae. These traps mimic tree trunks and are often effective for sampling species of Coleoptera that live in microhabitats associated with standing trees (Lindgren 1983). Traps were suspended from rope tied between two trees separated by at least $2 \mathrm{~m}$, with the collecting cup 30-50 $\mathrm{cm}$ above the ground. Collecting cups contained either a 50:50 mixture of propylene glycol and deionized water plus $0.5 \mathrm{ml} / \mathrm{L}$ of Kodak Photo-Flo 200 and $12.5 \mathrm{mg} / \mathrm{L}$ of Bitrex (in 2008) or a saturated salt solution with 1-2 drops of unscented dish detergent (in 2009 and 2010). Traps were baited with various lures reported as pheromones for longhorn species in the Cerambycinae subfamily (racemic 3-hydroxyhexan-2-one or racemic 3-hydroxyoctan-2-one) (Al- 
lison et al. 2004; Hanks et al. 2007) and/or high-release-rate ethanol lures (ConTech, Inc, Delta, BC), or were left unbaited. The effects of lure treatment on attraction (capture in Lindgren traps) of Staphylininae species and other by-catch species will be reported in separate papers. Samples were collected once weekly (2008 and 2009) or once every 2 weeks (2010), and specimens frozen until they were processed. A description of the habitat was recorded for all specimens collected during this survey. Locality and habitat data are presented exactly as on labels for each record. This information, as well as additional collecting notes, is summarized in the collection and habitat data section for each species.

\section{Specimen preparation}

Examples of most species of Staphylininae were dissected to confirm their identity. The genital structures were dehydrated in absolute alcohol, mounted in Canada balsam on celluloid microslides, and pinned with the specimens from which they originated.

\section{Distribution}

Distribution maps, created using ArcMap and ArcGIS, are presented for each species in New Brunswick. Every species is cited with current distribution in Canada and Alaska, using abbreviations for the state, provinces, and territories. New records for New Brunswick are indicated in bold under Distribution in Canada and Alaska. The following abbreviations are used in the text:

\begin{tabular}{ll|ll}
\hline AK & Alaska & MB & Manitoba \\
\hline YT & Yukon Territory & ON & Ontario \\
\hline NT & Northwest Territories & QC & Quebec \\
\hline NU & Nunavut & NB & New Brunswick \\
\hline BC & British Columbia & PE & Prince Edward Island \\
\hline AB & Alberta & NS & Nova Scotia \\
\hline SK & Saskatchewan & NF \& LB & Newfoundland and Labrador* \\
\hline
\end{tabular}

*Newfoundland and Labrador are each treated separately under the current Distribution in Canada and Alaska.

Acronyms of collections referred to in this study are as follows:

AFC Atlantic Forestry Centre, Natural Resources Canada, Canadian Forest Service, Fredericton, New Brunswick, Canada

CNC Canadian National Collection of Insects, Arachnids and Nematodes, Agriculture and Agri-Food Canada, Ottawa, Ontario, Canada

CCC C. Chantal Collection, Varennes, Quebec, Canada

NBM New Brunswick Museum, Saint John, New Brunswick, Canada

RWC Reginald Webster Collection, Charters Settlement, New Brunswick, Canada 


\section{Results}

Forty-four species of Staphylininae are newly recorded from New Brunswick; Bisnius cephalotes (Gravenhorst) is removed from the faunal list of New Brunswick because of lack of a supporting voucher specimen. We provide the first documented records of Atrecus americanus (Casey), Quedius erythrogaster Mannerheim, Quedius labradorensis labradorensis Smetana, Quedius plagiatus (Mannerheim), and Neobisnius terminalis (LeConte) from New Brunswick. This brings the total number of species known from the province to 126 (Table 1). Thirty-three of these species are newly recorded for the Maritime provinces (New Brunswick, Nova Scotia, Prince Edward Island) of Canada. Additional locality data are presented for seven species either recently recorded from the province or having few previous records and little bionomic data. Quedius criddlei (Casey) is reported for the first time from Quebec.

\section{Species accounts}

All records below are species newly recorded for New Brunswick, Canada, unless noted otherwise (additional records). Species followed by ${ }^{* *}$ are newly recorded from the Maritime provinces of Canada.

The classification of the Staphylininae follows Bouchard et al. (2011).

Subfamily Staphylininae, Latreille, 1802

Tribe Diochini Casey, 1906

Diochus schaumi Kraatz, 1860**

http://species-id.net/wiki/Diochus_schaumi

Map 1

Material examined. New Brunswick, York Co., Upper Brockway, $45.5684^{\circ} \mathrm{N}$, 67.0993 ${ }^{\circ} \mathrm{W}, 23 . I V .2006$, R. P. Webster, forested black spruce bog, in sphagnum. (1, RWC)

Collection and habitat data. The single New Brunswick specimen was collected from sphagnum in a forested black spruce (Picea mariana (Mill.) B.S.P.) bog. Elsewhere this species has been reported from forest litter and from wet moss and debris in wet habitats, such as swamps, marshes, bogs, and lake and stream margins (Smetana 1982). The single adult was collected by sifting sphagnum during late April.

Distribution in Canada and Alaska. ON, QC, NB (Smetana 1982). 


\section{Tribe Othiini Thomson, 1859}

Atrecus americanus (Casey, 1906)

http://species-id.net/wiki/Atrecus_americanus

Map 2

Material examined. Additional New Brunswick records, Albert Co., Caledonia Gorge P.N.A. (Protected Natural Area), at Turtle Creek, $45.8432^{\circ} \mathrm{N}, 64.8411^{\circ} \mathrm{W}$, 5.VII.2011, A. Fairweather, old hardwood forest (sugar maple and beech), in rotten $\log$ near creek (1, NBM); Caledonia Gorge P.N.A. at Caledonia Creek, $45.7935^{\circ} \mathrm{N}$, $64.7760^{\circ} \mathrm{W}$, 1.VII.2011, R. P. Webster, shaded, rocky, cold, clear brook, splashing moss on rocks (1, NBM). Carleton Co., Hovey Hill PNA, (Protected Natural Area), $46.1115^{\circ} \mathrm{N}, 67.7770^{\circ} \mathrm{W}, 19$. VIII.2007, R. P. Webster, hardwood forest, under bark.

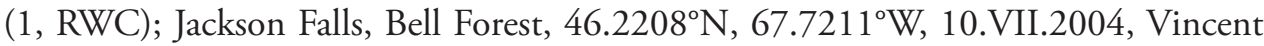
Webster \& R. P. Webster, mixed forest, in bracket fungi (1, RWC); same locality and forest type but $46.2200^{\circ} \mathrm{N}, 67.7231^{\circ} \mathrm{W}, 13 . \mathrm{VIII} .2006$, R. P. Webster, in decaying fleshy polypore fungi (1, RWC); same locality and forest type, 8-16.VI.2009, 16-21. VI.2009, 19-31.VII.2009, R. Webster \& M.-A. Giguère, Lindgren funnel traps (3, AFC). Queens Co., Cranberry Lake PNA, $46.1125^{\circ}$ N, 65.6075W, 21-27.V.2009, 21-28.VII.2009, 28.VII-6 VIII.2009, R. Webster \& M.-A. Giguère, mature red oak forest, Lindgren funnel traps (3, AFC). Restigouche Co., Berry Brook PNA, $47.8140^{\circ} \mathrm{N}, 66.7578^{\circ} \mathrm{W}, 26 . V .2007$, R .P. Webster, old-growth eastern white cedar swamp, in moss on hummock at base of cedar (2 $\hat{\jmath}$, RWC); Jacquet River Gorge PNA, $47.7491^{\circ} \mathrm{N}, 66.1114^{\circ} \mathrm{W}, 24$. VI.2008, R. P. Webster, hardwood forest, under bark (1, NBM). Sunbury Co., Acadia Research Forest, $45.9799^{\circ} \mathrm{N}, 66.3394^{\circ} \mathrm{W}, 14 . \mathrm{V} .2007$, R. P. Webster, mature red spruce and red maple forest, sifting deep conifer litter at base of large red spruce (1, AFC); Acadia Research Forest, $45.9866^{\circ} \mathrm{N}, 66.3841^{\circ} \mathrm{W}, 2-9$. VI.2009, 21-29.VII.2009, 29.VII-4.VIII.2009, R. Webster \& M.-A. Giguère, mature (110-year-old) red spruce forest with scattered red maple and balsam fir, Lindgren funnel traps (3, AFC). York Co., Charters Settlement, $45.8300^{\circ} \mathrm{N}, 66.7360^{\circ} \mathrm{W}, 1 . \mathrm{V} .2004$, R. P. Webster, mixed forest, under bark of conifer log (1, RWC); same locality data and collector but 21.VI.2004, mixed forest, under bark (1, RWC); same locality and collector but $45.8286^{\circ} \mathrm{N}, 66.7211^{\circ} \mathrm{W}, 10 . \mathrm{VII} .2005$, mature red spruce and cedar forest, in bracket fungi (1 $\mathrm{O}^{\mathrm{N}}$, RWC); Fredericton, Odell Park, 7.IX.2005, $45.9570^{\circ} \mathrm{N}$, $66.6695^{\circ} \mathrm{W}, \mathrm{R}$. P. Webster, old-growth hemlock forest, on bracket fungi (1, RWC); 15 $\mathrm{km} \mathrm{W}$ of Tracy off Rt. $645,45.6848^{\circ} \mathrm{N}, 66.8821^{\circ} \mathrm{W}, 1-8 . V I .2009$, R. Webster \& M.A. Giguère, old red pine forest, Lindgren funnel trap (1, AFC); $14 \mathrm{~km} \mathrm{WSW} \mathrm{of} \mathrm{Tracy,}$ S of Rt. $645,45.6741^{\circ} \mathrm{N}, 66.8661^{\circ} \mathrm{W}, 10-26 . V .2010$, R. Webster \& C. MacKay, coll., old mixed forest with red and white spruce, red and white pine, balsam fir, eastern white cedar, red maple, and Populus sp., Lindgren funnel trap (1, AFC).

Collection and habitat data. Smetana (1982) reported this species from under bark of dead trees with one record from Fomitopsis pinicola (Swartz: Fr.) Karst. In 
New Brunswick, this species was found in various forest types, including hardwood, mixed red spruce (Picea rubens Sarg.) and eastern white cedar (Thuja occidentalis L.), and old-growth hemlock (Tsuga canadensis (L.)). Adults were found under bark of both dead hardwood and conifer trees, in rotten logs, and in various species of polypore fungi (fleshy and bracket fungi). One adult was found in moss on a rock along a shaded brook. Adults were collected during May, June, July, August, and September.

Distribution in Canada and Alaska. ON, QC, NB, NS (Smetana 1982). Atrecus americanus was listed as occurring in New Brunswick by Majka et al. (2011) without any supporting references or data. Here, we provide the first documented records from New Brunswick.

\section{Tribe Xantholinini Erichson, 1839}

\section{Gyrohypnus campbelli Smetana, 1982}

http://species-id.net/wiki/Gyrohypnus_campbelli

Map 3

Material examined. New Brunswick, Restigouche Co., Jacquet River Gorge P.N.A, $47.7146^{\circ} \mathrm{N}, 66.1644^{\circ} \mathrm{W}, 24 . V I .2008$, R. P. Webster, alder swamp adjacent to slow flowing brook, in leaves on muddy soil ( 1 o , NBM). York Co., Charters Settlement, $45.8428^{\circ} \mathrm{N}, 66.7279^{\circ} \mathrm{W}, 19 . \mathrm{IV} .2005$, 28.IV.2004, R. P. Webster, mixed forest, in litter near small sedge marsh (2, RWC); same locality but $45.8395^{\circ} \mathrm{N}, 66.7391^{\circ} \mathrm{W}$, 23.IV.2004, 29.IV.2004, 9.V.2005, R. P. Webster, mixed forest near small shaded brook, in forest litter (2 $\sigma^{\lambda}, 3$ sex undetermined, NBM, RWC); same locality but $45.8341^{\circ} \mathrm{N}, 66.7445^{\circ} \mathrm{W}, 22 . I V .2005$, R. P. Webster, mature red spruce and eastern white cedar forest, margin vernal pond in leaf litter (2, RWC); New Maryland, off Hwy 2, E of Baker Brook, $45.8760^{\circ} \mathrm{N}, 66.6252^{\circ} \mathrm{W}, 6 . I V .2005$, R. P. Webster, old growth eastern cedar swamp in moss and litter on hummock (1, RWC); Rt. 645 at Beaver Brook, $45.6860^{\circ} \mathrm{N}, 66.8668^{\circ} \mathrm{W}, \mathrm{R}$. P. Webster, Carex marsh, in litter at base of

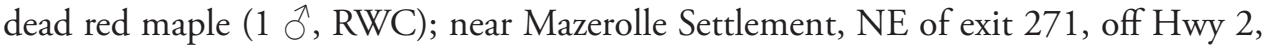
$45.8776^{\circ} \mathrm{N}, 66.8254^{\circ} \mathrm{W}, 8 . \mathrm{VI} .2008$, R. P. Webster, alder swamp with poplar, in leaf litter and moss near vernal pool (1, NBM).

Collection and habitat data. In New Brunswick, adults were usually found in moss, leaf, and grass litter near various kinds of wet habitats. These included Carex marshes, shaded brook margins, a vernal pond in a mature red spruce and eastern white cedar forest, and on hummocks in an old-growth eastern white cedar swamp. Elsewhere, this species has been found in similar habitats, including a series collected from a beaver lodge (Smetana 1982). Adults were collected during April, May, and June.

Distribution in Canada and Alaska. MB, ON, QC, NB, NS (Smetana 1982; Bishop et al. 2009). 


\section{Hypnogyra gularis (LeConte, 1880)**}

http://species-id.net/wiki/Hypnogyra_gularis

Map 4

Material examined. New Brunswick, Carleton Co., Jackson Falls, Bell Forest, $46.2200^{\circ} \mathrm{N}, 67.7231^{\circ} \mathrm{W}, 18 . I X .2006$, R. P. Webster, mature hardwood forest, under bark of large dead basswood covered with polypore fungi (1, RWC); same locality and habitat, 20-26.V.2009, R. Webster \& M.-A. Giguère, Lindgren funnel trap (1, RWC). Queens Co., Rees, near Grand Lake, $46.0016^{\circ} \mathrm{N}, 65.9466^{\circ} \mathrm{W}, 29 . \mathrm{V} .2007$, S. Makepeace \& R. P. Webster, nest box contents of barred owl (1, RWC); Cranberry Lake P.N.A., $46.1125^{\circ} \mathrm{N}, 65.6075^{\circ} \mathrm{W}, 5-12$ V.2009, R. Webster \& M.-A. Giguère, mature red oak forest, Lindgren funnel trap (1, RWC).

Collection and habitat data. Little is known about the habitat assciations of members of this genus, especially in North America (Smetana 1982). Species from the Palaearctic have been collected from hollows of trees and stumps and in litter at bases of dead trees; some species occur regularly in bird nests in hollow trees and are often observed among ants (Smetana 1982). In New Brunswick, one specimen was collected from the nest contents of a barred owl (Strix varia Barton), one from under the bark of a large, dead, fungus-covered basswood (Tilia americana L.) log, and another from a Lindgren funnel trap deployed in mature (old) red oak (Quercus rubra L.) forest. One specimen was collected in association with an ant, Formica subsericea Say, in Iowa City, Iowa (Smetana 1982). Adults were collected during May and September.

Distribution in Canada and Alaska. ON, NB (Smetana 1988).

\section{Neohypnus beckeri Smetana, 1982**}

http://species-id.net/wiki/Neohypnus_beckeri

Map 5

Material examined. New Brunswick, Carleton Co., Jackson Falls, Bell Forest, $46.2200^{\circ} \mathrm{N}$, 67.7231 ${ }^{\circ} \mathrm{W}, 23-28 . I V .2009,20-26 . V .2009$, R. Webster \& M.-A. Giguère, mature hardwood forest, Lindgren funnel traps (3, AFC). Charlotte Co., $10 \mathrm{~km} \mathrm{NW}$ of New River Beach, $45.2110^{\circ} \mathrm{N}, 66.6170^{\circ} \mathrm{W}, 30 . \mathrm{IV}-17 . V .2010$, R. Webster \& V. Webster, coll., old growth eastern white cedar forest, Lindgren funnel trap (1, AFC). Queens Co., Cranberry Lake P.N.A., $46.1125^{\circ} \mathrm{N}, 65.6075^{\circ} \mathrm{W}, 12-21 . V .2009,5-11 . V I .2009$, R. Webster \& M.A. Giguère, mature red oak forest, Lindgren funnel traps (2, AFC). Sunbury Co., Sunpoke Lake, $45.7665^{\circ} \mathrm{N}, 66.5545^{\circ} \mathrm{W}, 15$. V.2004, R. P. Webster, red oak and maple forest, under coyote scat and in leaf litter (2, RWC); Acadia Research Forest, $46.0188^{\circ} \mathrm{N}, 66.3765^{\circ} \mathrm{W}$, 14.V.2008, 18.VI.2009, R. P. Webster, mature red spruce and red maple forest, sifting leaf litter (2, AFC); Acadia Research Forest, $45.9866^{\circ} \mathrm{N}, 66.3841^{\circ} \mathrm{W}, 13-19 . \mathrm{V} .2009$, 19-25.V.2009, 25.V-2.VI.2009, 2-9.VI.2009, R. Webster \& M.-A. Giguère, mature (100-year-old) red spruce forest with scattered red maple and balsam fir, Lindgren funnel traps (6, AFC); ca. $5 \mathrm{~km} \mathrm{SE}$ of Geary, $45.7057^{\circ} \mathrm{N}, 66.4432^{\circ} \mathrm{W}, 22 . V .2009$, S. Makepeace 
\& R. Webster, in leaf litter with scat \& bones under tree with active great horned owl nest (1, NBM). York Co., Charters Settlement, $45.8304^{\circ} \mathrm{N}, 66.7351^{\circ} \mathrm{W}, 18 . \mathrm{IV} .2004$, 6.V.2004, R. P. Webster, mixed forest, under moist cardboard covering old chicken bones (2, RWC); same locality but $45.8395^{\circ} \mathrm{N}, 66.7391^{\circ} \mathrm{W}, 5 . V .2004,12 . V .2004,9 . V .2004$, R. P. Webster, mixed forest, in compost (decaying vegetables) (3, RWC); same locality but $45.8286^{\circ} \mathrm{N}, 66.7365^{\circ} \mathrm{W}, 7 . V I .2005$, R. P. Webster, mature red spruce and eastern white cedar forest, in leaf litter (2 , RWC); Canterbury, "Browns Mountain Fen Complex", $45.8937^{\circ} \mathrm{N}, 67.6564^{\circ} \mathrm{W}, 8 . V I .2004$, D. Sabine \& R. Webster, black spruce bog with eastern white cedar, in moist sphagnum on bog margin (1, RWC); $14 \mathrm{~km} \mathrm{WSW} \mathrm{of} \mathrm{Tracy,} \mathrm{S} \mathrm{of}$ Rt. 645, 45.6741 ${ }^{\circ} \mathrm{N}, 66.8661^{\circ} \mathrm{W}, 26 . \mathrm{IV}-10 . V .2010$, R. Webster \& C. MacKay, coll., old mixed forest with red and white spruce, red and white pine, balsam fir, eastern white cedar, red maple, and Populus sp., Lindgren funnel traps (2, AFC).

Collection and habitat data. In New Brunswick, adults were collected from under coyote scat, under cardboard covering old chicken bones, in compost, in leaf litter in hardwood and mixed forests, and in moist sphagnum on the margin of a black spruce and eastern white cedar bog/fen. Smetana (1982) reported most specimens from leaf litter in deciduous forests, although a few were reported from a human dung trap and from under a dead beaver. Adults were collected during April, May, and June.

Distribution in Canada and Alaska. ON, QC, NB (Smetana 1982).

\section{Phacophallus parumpunctatus (Gyllenhal, 1827)**}

http://species-id.net/wiki/Phacophallus_parumpunctatus

Map 6

Material examined. New Brunswick, York Co., Charters Settlement, $45.8395^{\circ} \mathrm{N}$, $66.7391^{\circ} \mathrm{W}, 16 . X .2004$, R. P. Webster, mixed forest, in compost (decaying vegetables) (1, RWC).

Collection and habitat data. In Europe, this species is synanthropic, occurring in compost, manure, and other decaying organic material (Smetana 1982). In North America, specimens of this adventive species were collected from decaying grass clippings and from a pile of moldy wood chips and damp decaying vegetation (Smetana 1982). The single specimen from New Brunswick was collected from decaying vegetables (compost) in October.

Distribution in Canada and Alaska. ON, QC, NB (Smetana 1982).

\section{Xestolinus abdominalis Casey, 1906** \\ http://species-id.net/wiki/Xestolinus_abdominalis \\ Map 7}

Material examined. New Brunswick, Sunbury Co., Acadia Research Forest, $46.0188^{\circ} \mathrm{N}, 66.3765^{\circ} \mathrm{W}, 14 . \mathrm{V} .2007$, R. P. Webster, mixed forest, in flight, collected 


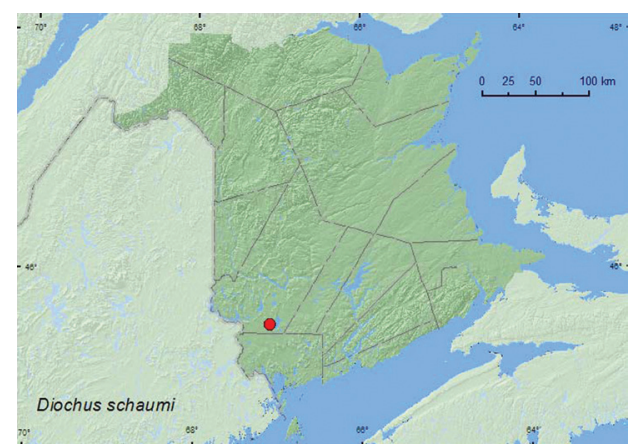

Map I. Collection localities in New Brunswick, Canada of Diochus schaumi.

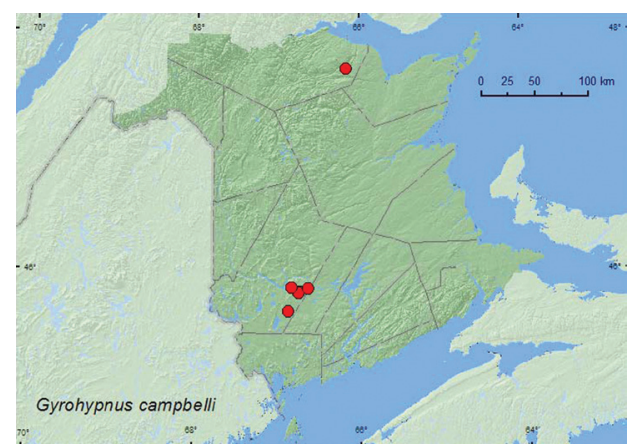

Map 3. Collection localities in New Brunswick, Canada of Gyrohypnus campbelli.

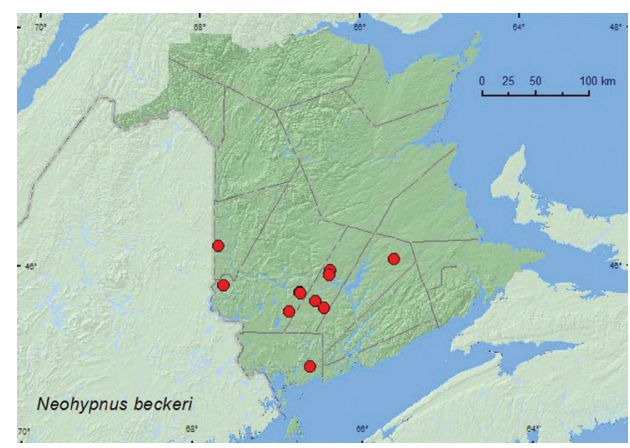

Map 5. Collection localities in New Brunswick, Canada of Neohypnus beckeri.

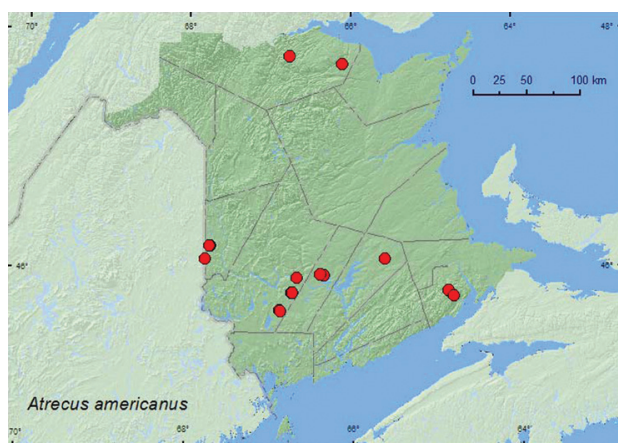

Map 2. Collection localities in New Brunswick, Canada of Atrecus americanus.

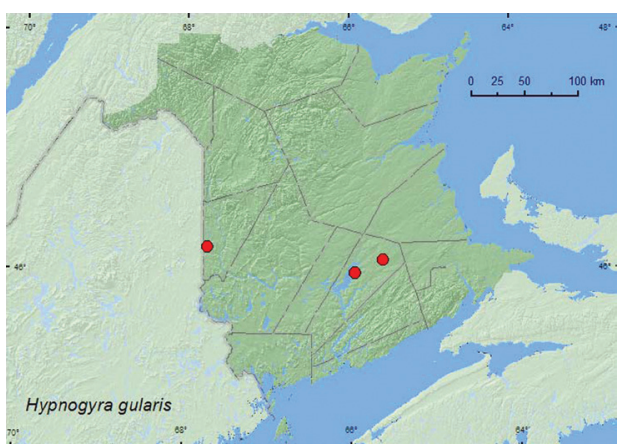

Map 4. Collection localities in New Brunswick, Canada of Hypnogyra gularis.

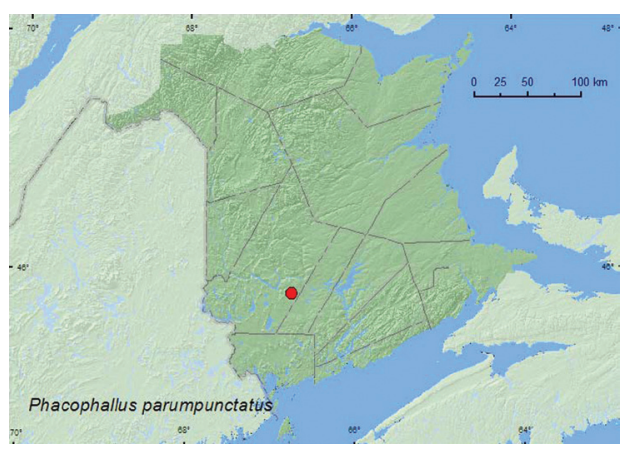

Map 6. Collection localities in New Brunswick, Canada of Phacophallus parumpunctatus. 
with net (1 sex undetermined, RWC). York Co., Charters Settlement, $45.8267^{\circ} \mathrm{N}$, $66.7343^{\circ} \mathrm{W}, 30 . I V .2005$, R. P. Webster, Carex marsh, in sphagnum hummock (1 sex undetermined, RWC).

Collection and habitat data. Little is known about the habitat associations of this species. One of the New Brunswick specimens was collected from a sphagnum hummock in a Carex marsh, another was collected while it was flying in a mixed forest near a Carex marsh. Adults were collected in late April and May.

Distribution in Canada and Alaska. SK, MB, ON, QC, NB (Smetana 1982).

Tribe Staphylinini Latreille, 1802

Subtribe Quediina Kraatz, 1857

Acylophorus (Amacylophorus) pratensis LeConte, 1863**

http://species-id.net/wiki/Acylophorus_pratensis

Map 8

Material examined. New Brunswick, Carleton Co., Jackson Falls, Bell Forest, $46.2150^{\circ} \mathrm{N}$, $67.7190^{\circ} \mathrm{W}, 12$.VI.2008, R. P. Webster, river margin, treading vegetation in seepage area (1, NBM). Charlotte Co., $3.5 \mathrm{~km}$ NW of Pomeroy Ridge, $45.3087^{\circ} \mathrm{N}, 67.4362^{\circ} \mathrm{W}$, 16.VI.2008, R. P. Webster, red maple swamp, in leaves and moss near small vernal pool (1, NBM). Northumberland Co., Goodfellow Brook P.N.A., 46.8943N, 65.3796 W, 23.V.2007, R. P. Webster, old growth eastern white cedar swamp, in grass litter and moss on hummocks near pool (1 $\delta, 1$ sex undetermined, NBM, RWC). Restigouche Co., Jacquet River Gorge P.N.A. at Jacquet River, $47.7765^{\circ}$ N, 66.1277º, 13.VIII.2010, R. P. Webster, in moss on rocks in middle of river, splashing rocks (1, NBM). York Co., Charters Settlement, $45.8395^{\circ} \mathrm{N}, 66.7391^{\circ} \mathrm{W}, 23 . I V .2004$, 3.VI.2004, 9.V.2005, 6.X.2005, R. P. Webster, mixed forest, in litter and moss near margin of small shaded brook (5, RWC); same locality and collector but $45.8283^{\circ} \mathrm{N}, 66.7350^{\circ} \mathrm{W}, 8 . \mathrm{V} .2004$, sedge marsh, in sphagnum hummock (1, RWC); same locality and collector but $45.8428^{\circ} \mathrm{N}, 66.7279^{\circ} \mathrm{W}$, 23.VI.2004, 20.IV.2005, mixed forest, (shaded) margin of small sedge marsh in moist sphagnum (2, RWC); $8.4 \mathrm{~km} \mathrm{~W}$ of Tracy off Rt. $645,45.6821^{\circ} \mathrm{N}, 66.7894^{\circ} \mathrm{W}, 14 . \mathrm{V} .2008$, R. P. Webster, wet alder swamp, in grass hummock (1, RWC).

Collection and habitat data. In New Brunswick, most adults were collected in red maple (Acer rubrum L.) swamps, alder (Alnus sp.) swamps, and eastern white cedar swamps, usually along vernal pool and brook margins, and in Carex marshes. One adult was collected from a seepage area along a river margin. Adults were sifted from moss and various kinds of grass and leaf litter. Elsewhere, specimens were collected from dead swamp grass and moss (Smetana 1971a), leaf litter in a cedar bog, and a pitfall trap in a bog (Smetana 1981). Adults in New Brunswick were collected in April, May, and June.

Distribution in Canada and Alaska. ON, QC, NB, NF (Smetana 1971a, 1973, 1981). 


\section{Acylophorus (Acylophorus) caseyi Leng, 1920}

http://species-id.net/wiki/Acylophorus_caseyi

Map 9

Material examined. New Brunswick, Charlotte Co., Rt. 3 at Deadwater Brook, $45.4744^{\circ} \mathrm{N}, 67.1225^{\circ} \mathrm{W}, 3 . V I .2005$, R. P. Webster, forested black spruce bog, marshy stream margin, treading (1, RWC); near New River, $45.1616^{\circ} \mathrm{N}, 66.6649^{\circ} \mathrm{W}$, 7.VII.2006, R. P. Webster, treading sedge marsh (1, NBM); near Clark Ridge, $45.3155^{\circ} \mathrm{N}, 67.4406^{\circ} \mathrm{W}, 27 . V .2007$, R. P. Webster, beaver pond, treading vegetation (1, NBM). Queens Co., Upper Gagetown, bog adjacent to Hwy 2, $45.8316^{\circ} \mathrm{N}$, $66.2346^{\circ} \mathrm{W}, \mathrm{R}$. P. Webster, tamarack bog, in sphagnum hummock and litter at bog margin (1 $\delta^{\lambda}, 2$ sex undetermined, NBM, RWC). York Co., Charters Settlement, $45.8267^{\circ} \mathrm{N}, 66.7343^{\circ} \mathrm{W}, 8$. V.2004, 16.IV.2005, 30.IV.2005, 14.V.2005, R. P. Webster, Carex marsh in sphagnum hummocks (5, RWC).

Additional Maine Record. Penobscot Co., T6 R8 WELS, Marble Fen, $46.1245^{\circ} \mathrm{N}, 68.6983^{\circ} \mathrm{W}, 13$. VI.2003, P. deMaynadier and R. Webster, open wet tamarack bog, in moist sphagnum (treading) (1, NBM).

Collection and habitat data. Smetana (1971a, 1976) reported this species from swampy and marshy areas, and along lake and bog margins. Adults occurred in wet moss, wet sphagnum, floating sphagnum mats, leaves and debris, and other floating vegetation. In Nova Scotia, adults were collected in a eutrophic, Typha latifolia L. marsh (Smetana 1965). In New Brunswick, this species was found in marsh vegetation or saturated sphagnum hummocks along a marshy stream margin near a forested black spruce bog, a tamarack (Larix laricina (Du Roi) Koch) bog, a beaver pond, and in Carex marshes. Most adults were collected by treading vegetation into water. Adults were collected in April, May, June, and July.

Distribution in Canada and Alaska. ON, QC, NB, NS (Smetana 1971a, 1973, 1976). Smetana (1990) reported A. caseyi from western Maine near the border with New Hampshire (Wilsons Mills Bog, Oxford Co.). The above record from Maine represents a significant eastern range extension in the state. It is apparent from the above records that $A$. caseyi probably has a more continuous distribution in the Northeast and the Maritime provinces as a whole than was suggested by the collection records reported in Majka et al. (2009). These distributional gaps likely reflect incomplete collecting effort in the appropriate wetland habitats. One must use treading to collect this species from the wetland habitats that this species usually frequents.

Hemiquedius ferox (LeConte, 1878)

http://species-id.net/wiki/Hemiquedius_ferox

Map 10

Material examined. New Brunswick, Carleton Co., Jackson Falls, $46.2257^{\circ} \mathrm{N}$, $67.7420^{\circ} \mathrm{W}, 22 . \mathrm{V} .2010$, R. P. Webster, river margin, in gravel near water on gravel bar 
(1, NBM). Charlotte Co., $3.0 \mathrm{~km}$ NW of Pomeroy Ridge, $45.3059^{\circ} \mathrm{N}, 67.4343^{\circ} \mathrm{W}$, 5.VI.2008, R. P. Webster, alder swamp, in moss hummocks with grasses (2, NBM, RWC); near New River, $45.2118^{\circ} \mathrm{N}, 66.6179^{\circ} \mathrm{W}, 7 . V I I .2008$, R. P. Webster, mixed forest, margin of small pond, treading Carex hummock (1, RWC). Queens Co., Grand Lake Meadows P.N.A., $45.8227^{\circ} \mathrm{N}, 66.1209^{\circ} \mathrm{W}, 24$. VIII-3.IX.2010, C. Hughes \& K. Burgess, old silver maple forest with green ash and seasonally flooded marsh, Lindgren funnel trap (1, AFC). Sunbury Co., Maugerville, Portobello Creek N.W.A., $45.8992^{\circ} \mathrm{N}, 66.4248^{\circ} \mathrm{W}, 27 . V .2004,5 . V I .2004$, R. P. Webster, silver maple swamp, margin of small vernal pond in leaf litter (2, RWC); near Sunpoke Lake, $45.7662^{\circ} \mathrm{N}$, $66.5526^{\circ} \mathrm{W}, 20 . \mathrm{VI} .2007$, R. P. Webster, seasonally flooded marsh, treading (1 sex undetermined, RWC). York Co., Fredericton, University of New Brunswick Woodlot, $45.9391^{\circ} \mathrm{N}, 66.6747^{\circ} \mathrm{W}, 17$. VIII.2009, R. Webster, D. McAlpine, \& G. Forbes, within wall of a beaver (Castor canadensis) lodge ( 4 , RWC).

Collection and habitat data. Hemiquedius ferox was reported by Smetana (1971a) from various wet habitats, such as swamps, lake margins, and marshes. Adults were found in wet moss and leaves and in beaver lodges in late fall. Adults were found in similar habitats in New Brunswick, including an alder swamp, silver maple (Acer saccharinum L.) swamps, pond margins, a seasonally flooded marsh, a gravel bar on river, and a beaver lodge. Adults occurred in moss and Carex hummocks, in leaf litter along vernal pond margins and within the wall of a beaver lodge. Adults were collected by sifting litter and moss or treading vegetation into water. One individual was collected in a Lindgren funnel trap. Adults were captured during May, June, July, August, and September.

Distribution in Canada and Alaska. ON, QC, NB, NS (Smetana 1971a). It is apparent from the above records that $H$. ferox is more widely distributed in the Maritime provinces than was suggested by the collection records reported in Majka et al. (2009).

\section{Heterothops minor Smetana, 1971}

http://species-id.net/wiki/Heterothops_minor

Map 11

Material examined. New Brunswick, York Co., Upper Brockway, $45.5684^{\circ} \mathrm{N}$, $67.0993^{\circ} \mathrm{W}, 23 . I V .2006$, R. P. Webster, forested black spruce bog, in sphagnum (1, RWC).

Collection and habitat data. Little is known about the habitat associations of this species. Smetana (1976) reported specimens from under driftwood on a muddy river bank and from a pitfall trap on the margin of swampy pool in the Northwest Territories. The single adult from New Brunswick was sifted from sphagnum in a forested black spruce bog in late April. 
Distribution in Canada and Alaska. NT, BC, AB, MB, ON, QC, NB, NS, NF (Smetana 1971a, 1973, 1976, 1981).

\section{Heterothops pusio LeConte, $1863^{* *}$}

http://species-id.net/wiki/Heterothops_pusio

Map 12

Material examined. New Brunswick, Carleton Co., Jackson Falls, Bell Forest, $46.2152^{\circ} \mathrm{N}, 67.7190^{\circ} \mathrm{W}, 1 . V I .2005$, M.-A. Giguère \& R. Webster, river margin, flying adults collected with aerial net between 16:00 and 18:00 h (1 $\hat{0}, 1$ q, RWC). Restigouche Co., Jacquet River Gorge P.N.A., $47.8197^{\circ} \mathrm{N}, 66.0835^{\circ} \mathrm{W}, 23 . \mathrm{VI} .2008$, R. P. Webster, river margin, among cobblestones (1, NBM). York Co., Charters Settlement, $45.8395^{\circ} \mathrm{N}, 66.7391^{\circ} \mathrm{W}, 10 . \mathrm{VI} .2006$, R. P. Webster, mixed forest, m.v. light (3, RWC); same locality data, collector, and forest type, 26.V.2008, compost (decaying vegetables) (1, RWC).

Collection and habitat data. Smetana (1971a) reported this species from compost and grass piles, leaf and ground litter, and from old deserted beaver lodges. In New Brunswick, adults were sifted from compost and among cobblestones along a river margin. Other individuals were collected at a mercury-vapor light and during a late afternoon aerial flight. Adults were collected in May and June.

Distribution in Canada and Alaska. BC, ON, QC, NB (Smetana 1971a, 1973, 1981).

Quedius (Microsaurus) campbelli Smetana, 1971**

http://species-id.net/wiki/Quedius_campbelli

Map 13

Material examined. New Brunswick, Restigouche, Co., Dionne Brook P.N.A., $47.9064^{\circ} \mathrm{N}, 68.3441^{\circ} \mathrm{W}, 31 . \mathrm{V}-15 . \mathrm{VI} .2011$, M. Roy \& V. Webster, old-growth white spruce and balsam fir forest, Lindgren funnel trap (1 9 , RWC). York Co., Fredericton, University of New Brunswick Woodlot, $45.9391^{\circ} \mathrm{N}, 66.6747^{\circ} \mathrm{W}, 17 . \mathrm{VIII} .2009$, R. P. Webster, D. McAlpine, \& G. Forbes, in beaver (Castor canadensis) lodge, within wall of lodge ( $2 \hat{\jmath}$, NBM, RWC).

Collection and habitat data. Smetana (1971a, 1976) reported specimens from near or within (in walls) muskrat nests and beaver lodges. Two of the New Brunswick specimens were collected from within the wall of a beaver lodge in August. One was captured during June in a Lindgren funnel trap deployed in an old balsam fir (Abies balsamea (L.) Mill.) and white spruce (Picea glauca (Moench) Voss) forest.

Distribution in Canada and Alaska. ON, QC, NB (Smetana 1971a, 1976). 


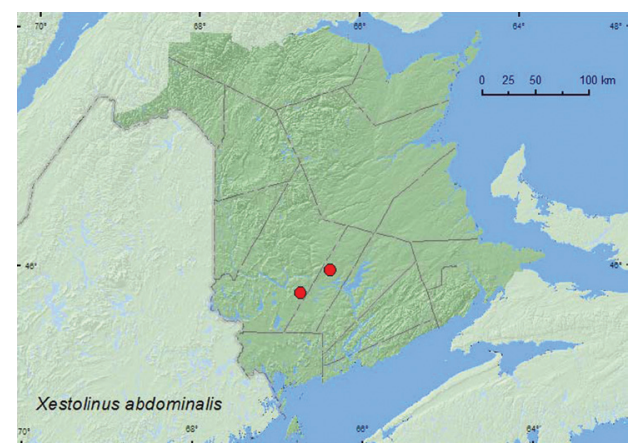

Map 7. Collection localities in New Brunswick, Canada of Xestolinus abdominalis.

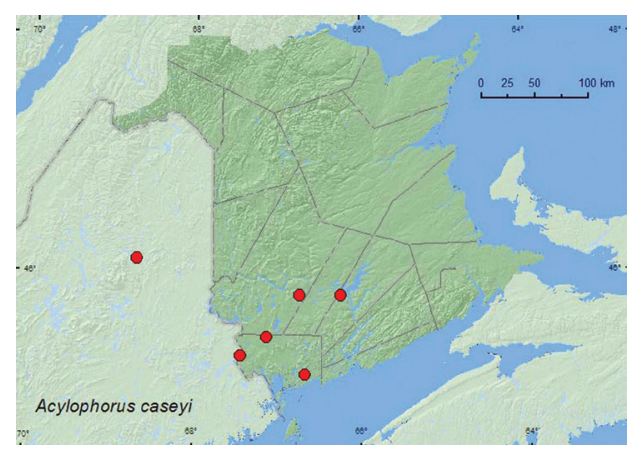

Map 9. Collection localities in New Brunswick, Canada and Maine, United States of America of Acylophorus caseyi.

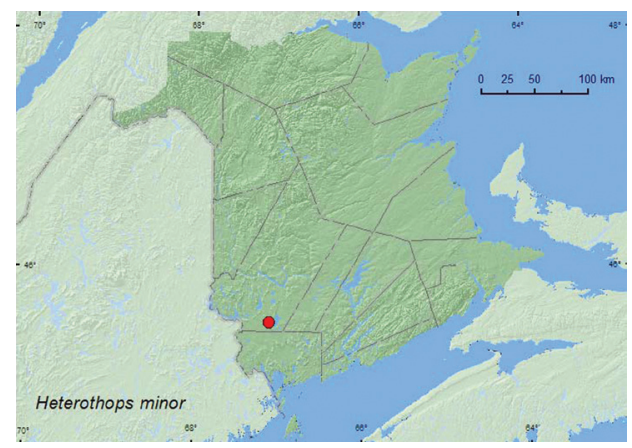

Map I I. Collection localities in New Brunswick, Canada of Heterothops minor.

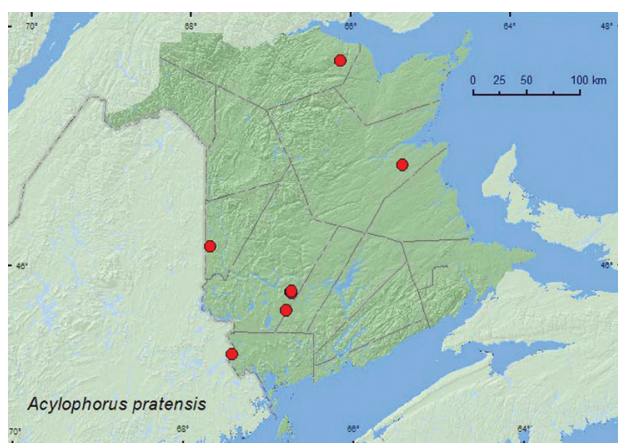

Map 8. Collection localities in New Brunswick, Canada of Acylophorus pratensis.

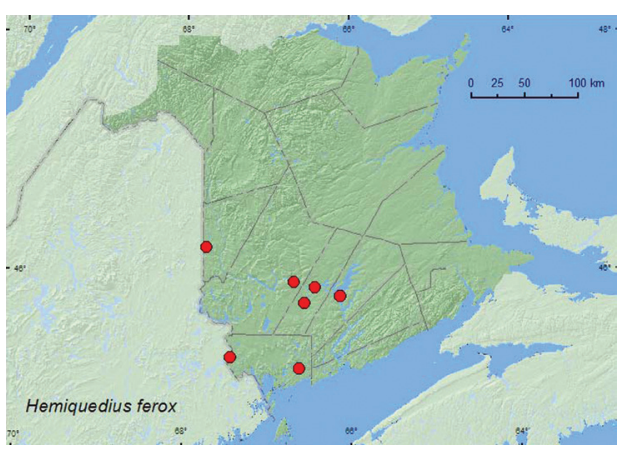

Map 10. Collection localities in New Brunswick, Canada of Hemiquedius ferox.

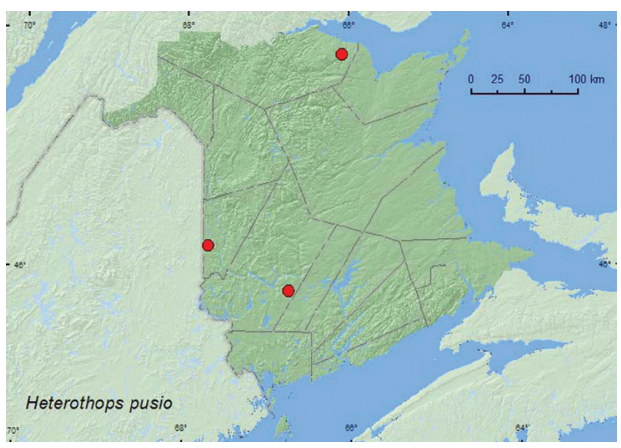

Map 12. Collection localities in New Brunswick, Canada of Heterothops pusio. 
Quedius (Microsaurus) canadensis (Casey, 1915)

http://species-id.net/wiki/Quedius_canadensis

Map 14

Material examined. Additional New Brunswick records. Carleton Co., Jackson Falls, Bell Forest, $46.2200^{\circ} \mathrm{N}, 67.7231^{\circ} \mathrm{W}, 18 . I X .2006$, R. P. Webster, mature hardwood forest, under bark of large, dead, standing basswood covered with bracket fungi (1 $\widehat{\partial}$, RWC); same locality, 4-12.VI.2008, 12-19.VI.2008, 5-12.VII.2008, 23-28.IV.2009, 9-14.V.2009, 14-20.V.2009, 9-16.VI.2009, R. Webster \& M.-A. Giguère, mature hardwood forest,

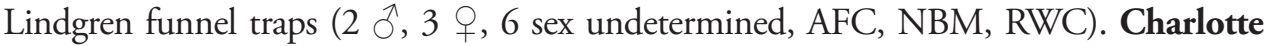
Co., $10 \mathrm{~km} \mathrm{NW}$ of New River Beach, $45.2110^{\circ} \mathrm{N}, 66.6170^{\circ} \mathrm{W}, 30 . \mathrm{IV}-17 . V .2010$, R. P. Webster \& V. Webster, coll., old-growth eastern white cedar forest, Lindgren funnel trap (1, AFC). Queens Co., Cranberry Lake P.N.A., 46.1125N, 65.6075² W, 24.IV-5 V.2009, R. Webster \& M.-A. Giguère, mature red oak forest, Lindgren funnel traps (5, AFC, NBM). Restigouche Co., Jacquet River Gorge P.N.A., $47.8160^{\circ} \mathrm{N}, 66.0083^{\circ} \mathrm{W}, 14$. VIII.2010, R. P. Webster, old eastern white cedar forest, in polypore fungi on Populus log (1, NBM); Dionne Brook P.N.A., 47.9030N, 68.3503ํW, 28.VII-9.VIII.2011, 9-23.VIII.2011, M. Roy \& V. Webster, old-growth northern hardwood forest, Lindgren funnel trap (2, NBM); same locality and collectors but $47.9064^{\circ} \mathrm{N}, 68.3441^{\circ} \mathrm{W}, 27 . \mathrm{VI}-14 . \mathrm{VII} .2011,9-23$. VIII.2011, old-growth white spruce and balsam fir forest, Lindgren funnel traps (2, AFC, NBM). Sunbury Co., Acadia Research Forest, $45.9866^{\circ} \mathrm{N}, 66.3841^{\circ} \mathrm{W}, 28 . I V-8 . V .2009$, 8-13.V.2009, 13-19.V.2009, 2-9.VI.2009, 29.VII-4.VIII.2009, R. Webster \& M.-A. Giguère, mature (110 year-old) red spruce forest with scattered red maple and balsam fir, Lindgren funnel traps ( 1 ऽ, 13 sex undetermined, AFC, RWC). York Co., Charters Settlement, $45.8395^{\circ} \mathrm{N}, 66.7391^{\circ} \mathrm{W}, 25-29 . I V .2008$, R. P. Webster, mixed forest, Lindgren funnel trap ( 1 $\mathrm{O}^{\mathrm{N}}$, RWC); $15 \mathrm{~km} \mathrm{~W}$ of Tracy, off Rt. $645,45.6848^{\circ} \mathrm{N}, 66.8821^{\circ} \mathrm{W}, 25 . \mathrm{IV}$ 4V.2009, 4-11.V.2009, 11-19.V.2009, R. Webster \& M.-A. Giguère, mature (120-180 year-old) red pine forest, Lindgren funnel traps ( 3 $\widehat{A}, 4$ sex undetermined, AFC, RWC); $14 \mathrm{~km}$ WSW of Tracy, S of Rt. 645, $45.6741^{\circ} \mathrm{N}, 66.8661^{\circ} \mathrm{W}, 26 . I V-10 . V .2010$, R. Webster \& C. MacKay, coll., old mixed forest with red and white spruce, red and white pine, balsam fir, eastern white cedar, red maple, and Populus sp., Lindgren funnel traps (2, AFC).

Collection and habitat data. Little is known about the habitat associations of this species. Smetana (1973) reported a specimen from Polyporus betulinus (Bull.) Fr. In New Brunswick, one specimen was collected from under bark of a large, dead, standing basswood covered with bracket fungi (polypore fungi), one from under bark of a spruce $\log$, and another in a polypore fungi on a Populus log. Many specimens were captured in Lindgren funnel traps deployed in a variety of forest types, including an old red pine (Pinus resinosa Ait.) forest, a hardwood with sugar maple (Acer saccharum Marsh.) and American beech (Fagus grandifolia Ehrh.), an old-growth northern hardwood forest, a red spruce forest, an old-growth white spruce and balsam fir forest, a mixed forest, and an old eastern white cedar forest. These traps mimic tree trunks (Lindgren 1983), and it is possible that this species lives in microhabitats associated with standing trees. Adults were collected in April, May, June, July, August, and September. 
Distribution in Canada and Alaska. ON, QC, NB, NS (Smetana 1971a, 1973, 1978; Bishop et al. 2009). This species was previously known in New Brunswick from one specimen collected in Dalhousie during 1925 by Johansen (Smetana 1971a).

\section{Quedius (Microsaurus) criddlei (Casey, 1915)**}

http://species-id.net/wiki/Quedius_criddlei

Map 15

Material examined. New Brunswick, Queens Co., Cranberry Lake P.N.A., $46.1125^{\circ} \mathrm{N}$, 65.6075W, 7-13.VII.2011, 20.VII-4.VIII.2011, M. Roy \& V. Webster, old red oak forest, Lindgren funnel trap (2 9 , NBM, RWC). Restigouche Co., Dionne Brook P.N.A., $47.9030^{\circ} \mathrm{N}, 68.3503^{\circ} \mathrm{W}, 27$. VI-14.VII.2011, 9-23.VIII.2011, M. Roy \& V. Webster, oldgrowth northern hardwood forest, Lindgren funnel traps (2 $⿱$, 2 ,, NBM, RWC); same locality and collectors but $47.9064^{\circ} \mathrm{N}, 68.3441^{\circ} \mathrm{W}, 31 . V-15 . V I .2011,15-27 . V I .2011$, 27.VI-14.VII.2011, 14-28.VII.2011, 9-23.VIII.2011, old-growth white spruce and balsam fir forest, Lindgren funnel traps (3 3,6 , AFC, NBM, RWC). York Co., $15 \mathrm{~km} \mathrm{~W}$ of Tracy off Rt. 645, $45.6848^{\circ} \mathrm{N}, 66.8821^{\circ} \mathrm{W}, 1-8 . V I .2009$, R. Webster \& M.-A. Giguère, old red pine forest, Lindgren funnel trap (1 $9, \mathrm{RWC})$; same locality and habitat data,

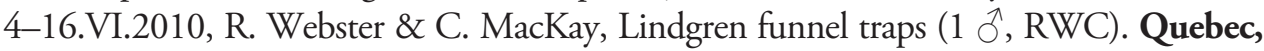
Saguenay Co. Sept-Iles, 20.V.1985, 13.IX.1985, C. Chantal (1ð, 1 ㅇ, CCC).

Collection and habitat data. Little is known about the habitat associations of this species. Adults have been taken from leaf litter in Larix forests, in rotten Douglasfir (Pseudotsuga taxifolia Britton) and grand fir (Abies grandis (Douglas ex. D. Don) Lindl.) logs, under board in a meadow, ex fungus, and in association with the ant Formica neorufibarbis Emery (probably accidentally) (Smetana 1971a). The New Brunswick specimens were collected in Lindgren funnel traps deployed in an old (120- to 180-year-old trees) red pine forest, an old red oak forest, an old-growth northern hardwood forest, and an old-growth white spruce and balsam fir forest. Adults were collected during May, June, July, August, and September in New Brunswick and Quebec.

Distribution in Canada and Alaska. NT, YT, BC, AB, MB, ON, QC, NB (Smetana 1971a, 1990). The records from Quebec and New Brunswick represent significant range extensions east of the known distribution of this species reported by Smetana (1971a, 1990), indicating that this species is transcontinental in distribution in Canada.

Quedius (Microsaurus) erythrogaster Mannerheim, 1852

http://species-id.net/wiki/Quedius_erythrogaster

Map 16

Material examined. Additional New Brunswick records, Carleton Co., Jackson Falls, Bell Forest, $46.2208^{\circ} \mathrm{N}, 67.7211^{\circ} \mathrm{W}, 10 . I V .2005$, R. P. Webster, mature hardwood forest, in leaf litter at base of tree ( $1 \hat{\sigma}$, RWC). Queens Co., Cranberry Lake 
P.N.A., $46.1125^{\circ} \mathrm{N}, 65.6075^{\circ} \mathrm{W}, 24 . I V-5$ V.2009, 5-12 V.2009, R. Webster \& M.-A. Giguère, mature red oak forest, Lindgren funnel traps (2, AFC). Restigouche Co., Dionne Brook P.N.A., $47.9030^{\circ}$ N, 68.3503ํ․, 27.VI-14.VII.2011, M. Roy $\&$ V. Webster, old-growth northern hardwood forest, Lindgren funnel traps (1 $\hat{\delta}, 2$ , NBM, RWC). Sunbury Co., Noonan, $45.9923^{\circ} \mathrm{N}, 66.4099^{\circ} \mathrm{W}, 22$. VI.2007, S. Makepeace \& R. Webster, mature mixed forest, in nest contents of barred owl, $7 \mathrm{~m}$ high in cavity in a red maple ( 1 $\left.\mathrm{O}^{\mathrm{N}}, 1 \mathrm{O}, \mathrm{RWC}\right)$; Acadia Research Forest, $45.9866^{\circ} \mathrm{N}$, 66.3841 ${ }^{\circ} \mathrm{W}, 22-25 . I V .2009,25 . I V-4 . V .2009$, 4-11.V.2009, 19-25.V.2009, R. Webster \& M.-A. Giguère, mature (110-year-old) red spruce forest with scattered red maple and balsam fir, Lindgren funnel traps (4, AFC). York Co., Charters Settlement, $45.8395^{\circ} \mathrm{N}, 66.7391^{\circ} \mathrm{W}, 18 . I V .2004,30 . I V .2004,5 . V .2006,9 . V .2006$, R. P. Webster, mixed forest, in compost (decaying vegetables) (2 $0^{\lambda}, 2$, $\mathrm{RWC}$ ); same locality but $45.8430^{\circ} \mathrm{N}, 66.7275^{\circ} \mathrm{W}, 6 . X .2005$, R. P. Webster, regenerating mixed forest, baited with pile of decaying mushrooms ( 2 , RWC); $15 \mathrm{~km}$ W of Tracy off Rt. 645, 45.6848 $\mathrm{N}, 66.8821^{\circ} \mathrm{W}, 22-25 . I V .2009,25 . I V-4 . V .2009,4-11 . V .2009$, 19-25.V.2009, R. Webster \& M.-A. Giguère, Lindgren funnel traps (4, AFC).

Collection and habitat data. Quedius erythrogaster typically lives in nests and burrows of various mammals and in caves but has been found in decaying organic matter and debris (Smetana 1971a), including wet leaf litter (Smetana 1976). In New Brunswick, adults were found in leaf litter early in the season when snow was still present (possibly an overwinter site), compost (decaying vegetables), and decaying mushrooms. Other adults were collected from the nest contents of a barred owl in a tree hole, suggesting this species may also live in association with tree-cavity-nesting birds. Adults were also captured in Lindgren funnels traps deployed in an old red oak forest, an old red pine forest, and an old-growth northern hardwood forest. Adults were collected in April, May, June, July, and October.

Distribution in Canada and Alaska. BC, AB, SK, ON, QC, NB (Smetana 1971a, 1973, 1976, 1981). Quedius erythrogaster was listed as occurring in New Brunswick by Majka et al. (2011) without any supporting references or data. Here, we provide the first documented records from New Brunswick.

\section{Quedius (Microsaurus) mesomelinus (Marsham, 1802)}

http://species-id.net/wiki/Quedius_mesomelinus

Map 17

Material examined. Additional New Brunswick records, Carleton Co., Jackson Falls, Bell Forest, $46.2200^{\circ} \mathrm{N}$, 67.7231 ${ }^{\circ} \mathrm{W}$, 18.IX.2006, 9.X.2006, R. P. Webster, mature hardwood forest, under bark of large dead standing basswood covered with bracket fungi (1 ${ }^{\lambda}, 1$ \% , RWC); same locality, 4-12.VI.2008, 12-19.VI.2008, 19-27. VI.2008, 5-12.VII.2008, 12-19.VII.2008, 19-28.VII.2008, R. P. Webster, mature hardwood forest, Lindgren funnel traps ( $2 \hat{O}, 4$ +, 7 sex undetermined, AFC, RWC); same locality, 14-20.V.2009, 16-21.VI.2009 , R. Webster \& M.-A. Giguère, mature 
hardwood forest, Lindgren funnel traps (2, AFC). Restigouche, Co., Dionne Brook P.N.A., $47.9064^{\circ} \mathrm{N}, 68.3441^{\circ} \mathrm{W}, 27 . \mathrm{VI}-14 . V I I .2011$, M. Roy \& V. Webster, oldgrowth white spruce and balsam fir forest, Lindgren funnel trap (1, NBM). York Co., Odell Park, $45.9570^{\circ} \mathrm{N}, 66.6695^{\circ} \mathrm{W}, 19 . \mathrm{VI} .2005$, R. P. Webster, moist wood chips and decaying plant material (1 9 , RWC).

Collection and habitat data. In Europe, this species is typically found in synanthropic situations in decaying organic materials such as compost (Smetana 1971a). It has also been reported from mammal burrows, tree holes, and caves in natural settings. In New Brunswick, adults were collected from under bark of a fungus-covered, dead, standing basswood, among moist wood chips and decaying plant material, and from Lindgren funnel traps deployed in a hardwood forest and an old-growth white spruce and balsam fir forest. Adults were captured in June, July, September, and October.

Distribution in Canada and Alaska. AK, BC, AB, MB, ON, QC, NB, NS, NF (Smetana 1971a; Majka and Smetana 2007). This adventive species was first reported from New Brunswick by Majka and Smetana (2007) from specimens collected in Saint John in 1907 by G. Morrisey.

\section{Quedius (Microsaurus) peregrinus Gravenhorst, 1806}

http://species-id.net/wiki/Quedius_peregrinus

Map 18

Material examined. Additional New Brunswick records. Albert Co., Caledonia Gorge P.N.A., $45.8257^{\circ} \mathrm{N}, 64.7791^{\circ} \mathrm{W}, 6 . \mathrm{VII} .2011$, R. P. Webster, old hardwood forest (sugar maple and beech), in decayed fleshy polypore in log ( $1 \hat{\sigma}, \mathrm{NBM})$. Sunbury Co., Maugerville, Portobello Creek N.W.A., 45.9031 ${ }^{\circ} \mathrm{N}, 66.4268^{\circ} \mathrm{W}, 11 . \mathrm{IX} .2006$, R. P. Webster, red oak and red maple forest, on gilled mushroom (1 9 , RWC); Acadia Research Forest, pitfall trap (collection) dates, 17.VIII.1999, 24.VIII.1999, 25.VIII.1999, 8.IX.1999, 13.IX.1999, 15.IX.1999, G. Gesner, strip, select., and control plots (15, AFC); same locality but $46.0188^{\circ} \mathrm{N}, 66.3765^{\circ} \mathrm{W}, 17$. VIII.2007, R. P. Webster, mature red spruce and red maple forest, sifting moss (1, AFC); same locality and collector but $46.0173^{\circ} \mathrm{N}, 66.3741^{\circ} \mathrm{W}, 18 . \mathrm{IX} .2007,8.5$ year-old regenerating mixed forest, in sphagnum and leaf litter at bottom of old tire depression (1, AFC). York Co., Charters Settlement, $45.8395^{\circ} \mathrm{N}, 66.7391^{\circ} \mathrm{W}, 18$. VII.2006, R. P. Webster, mixed forest, on rotting fungus covered $\log (1$ \% , RWC); same locality data, collector, and (adjacent) forest type, 4.X.2005, residential lawn, on soil at base of grasses (1 $\left.\sigma^{\lambda}, \mathrm{RWC}\right)$; same locality, collector, and adjacent forest type but $45.8348^{\circ} \mathrm{N}, 66.7335^{\circ} \mathrm{W}, 4$. VIII.2004, in fleshy fungi (1, NBM); same locality and collector but $45.8430^{\circ} \mathrm{N}, 66.7275^{\circ} \mathrm{W}, 12 . \mathrm{VII} .2005$, regenerating mixed forest, beating foliage ( $2 \hat{\jmath}, 3$,, RWC); same locality data, collector, and forest type, 25.IX.2005, baited with pile of decaying mushrooms (1 $\lesssim$, RWC).

Collection and habitat data. One of the Nova Scotia specimens was collected by treading wet Sphagnum (Smetana 1973), otherwise little is known about the habitat 
associations of this species (Smetana 1971a). Specimens from New Brunswick were collected in red oak and red maple forests, a red spruce and red maple forest, an old sugar maple and American beech forest, and regenerating mixed forests. Adults were collected from gilled mushrooms, a decayed fleshy polypore fungus on a log, from a rotten fungus-covered log, baited with decaying mushrooms, sifted from sphagnum and leaf litter at bottom of old tire depression, and swept from foliage in a regenerating forest. Adults were also captured in pitfall traps in large numbers (Klimaszewski et al. 2005). This species is probably associated with decaying organic matter, such as decaying mushrooms. Adults were captured during July, August, September, and October.

Distribution in Canada and Alaska. ON, QC, NB, NS (Smetana 1971a, 1973; Klimaszewski et al. 2005). This species was first reported from New Brunswick by Klimaszewski et al. (2005) from specimens collected in pitfall traps at the Acadia Research Forest (Sunbury Co.)

\section{Quedius (Quedius) curtipennis Bernhauer, 1908}

http://species-id.net/wiki/Quedius_curtipennis

Map 19

Material examined. Additional New Brunswick records. Carleton Co., Jackson Falls, Bell Forest, $46.2152^{\circ} \mathrm{N}, 67.7190^{\circ} \mathrm{W}, 21$. VIII.2004, 15.IX.2004, R. P. Webster, upper river margin under litter on clay soil (2 9 , RWC); Hovey Hill P.N.A., $46.1115^{\circ} \mathrm{N}, 67.7770^{\circ} \mathrm{W}, 10 . \mathrm{V} .2005$, R. P. Webster, mature hardwood forest in moist leaf litter and moss on margin of vernal pond $(2 \hat{\delta}, 1 q$, RWC). York Co., Pokiok, 2.VI.1995, (G. Gesner) pitfall trap (10, AFC); Charters Settlement, $45.8395^{\circ} \mathrm{N}$, $66.7391^{\circ} \mathrm{W}, 30 . \mathrm{IV} .2005$, R. P. Webster, mixed forest, in compost (decaying vegetables) ( 1 J, RWC); same locality data, collector, and forest type, 5.IX.2006, in pile of decaying corncobs and cornhusks ( 1 , RWC).

Collection and habitat data. This species has been reported mostly from around human settlements in various kinds of debris and under stones (Smetana (1971a). Adults have also been found in natural habitats in moss and leaf litter (Smetana 1971a, 1978). In New Brunswick, adults were collected in natural habitats (river margin in litter, in moist leaf litter and moss on vernal pond margin in a hardwood forest) and in synanthropic situations (in compost and pile of decaying corncobs and cornhusks near a home). Adults were collected in April, May, June, August, and September.

Distribution in Canada and Alaska. BC, ON, NB, NS (Smetana 1971a; Majka and Smetana 2007; Brunke and Marshall 2011). This adventive species was first reported from New Brunswick and Nova Scotia (and eastern North America) by Majka and Smetana (2007). An earlier record (Truro, 1984) from Nova Scotia was later reported by Majka and Klimaszewski (2008a). The record from New Brunswick was based on a specimen collected by CG Majka at Mary's Point in 2002. 


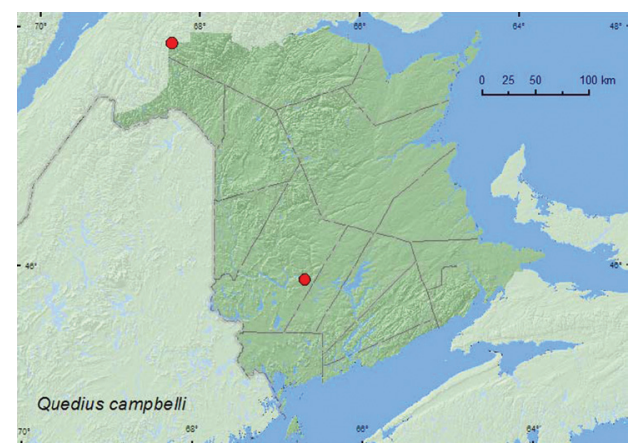

Map 13. Collection localities in New Brunswick, Canada of Quedius campbelli.

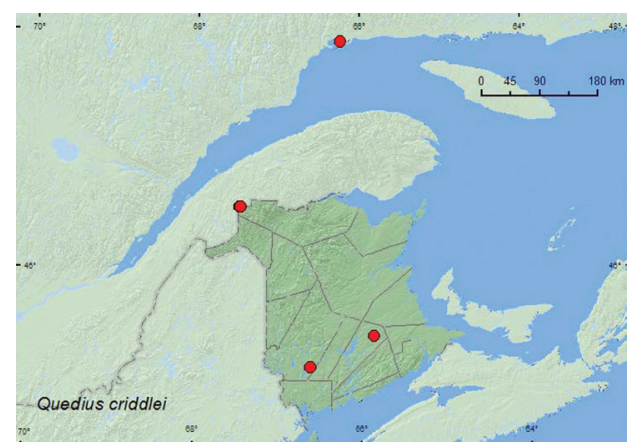

Map 15. Collection localities in New Brunswick and Quebec, Canada of Quedius criddlei.

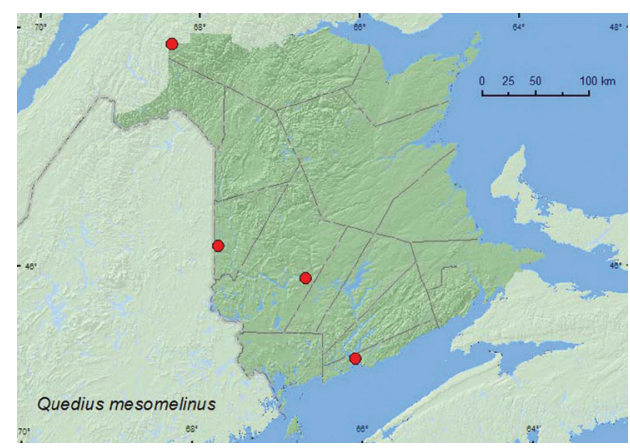

Map 17. Collection localities in New Brunswick, Canada of Quedius mesomelinus.

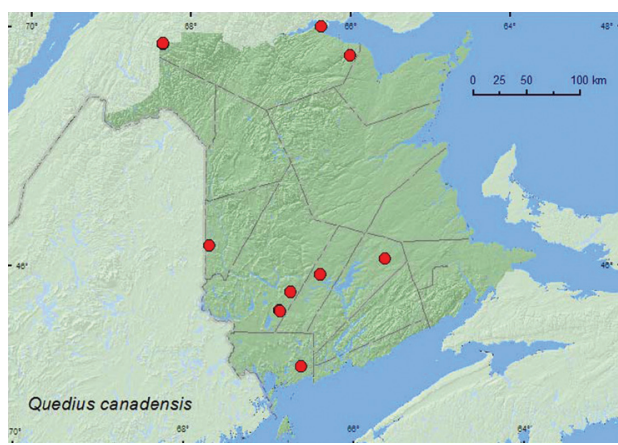

Map 14. Collection localities in New Brunswick, Canada of Quedius canadensis.

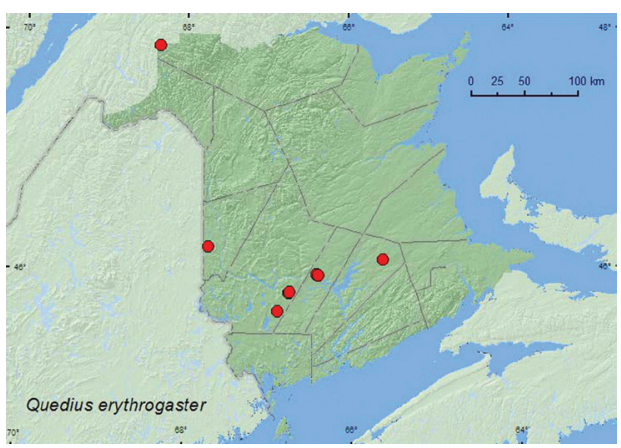

Map 16. Collection localities in New Brunswick, Canada of Quedius erythrogaster.

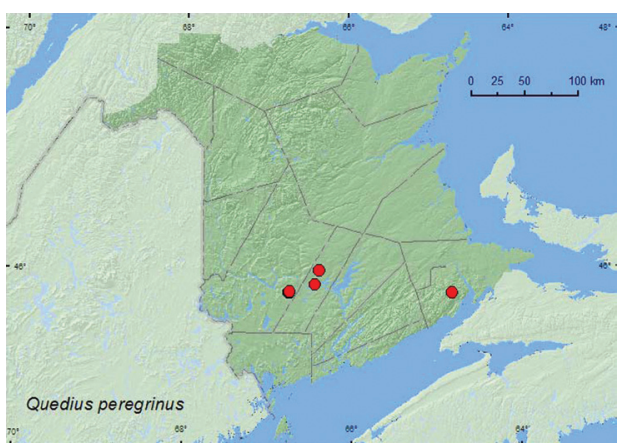

Map 18. Collection localities in New Brunswick, Canada of Quedius peregrinus. 
Quedius (Quedius) labradorensis labradorensis Smetana, 1965

http://species-id.net/wiki/Quedius_labradorensis_labradorensis

Map 20

Material examined. Additional New Brunswick records, Restigouche Co., Little Tobique River near Red Brook, $47.4462^{\circ} \mathrm{N}, 67.0689^{\circ} \mathrm{W}, 24 . V .2007$, R. P. Webster, coll., old growth eastern white cedar forest, in moss and leaf litter near brook (1 $\mathrm{J}^{\text {, }}$ NBM); MacFarlane Brook P.N.A., $47.6018^{\circ}$ N, $67.6263^{\circ} \mathrm{W}, 25 . V .2007$, R. P. Webster, old growth eastern white cedar swamp, in moss near brook (1 $\delta^{7}$, RWC); Berry Brook P.N.A., $47.8140^{\circ} \mathrm{N}, 66.7578^{\circ} \mathrm{W}, 26 . V .2007$, R. P. Webster, old growth eastern white cedar swamp, in moss on hummock at base of eastern white cedar ( 2 +, RWC). Saint John Co., Musquash, $45.1696^{\circ} \mathrm{N}, 66.3140^{\circ} \mathrm{W}, 7 . V .2006$, R. P. Webster, spruce forest, in sphagnum and litter on margin of brook (1 $\sigma^{\lambda}$, RWC); ca. $2.0 \mathrm{~km} \mathrm{NE}$ of Maces Bay, $45.1168^{\circ} \mathrm{N}, 66.4552^{\circ} \mathrm{W}, 8$. V.2006, R. P. Webster, eastern white cedar swamp, under deer dung ( 1 Oे, RWC). York Co., Charters Settlement, $45.8395^{\circ} \mathrm{N}, 66.7391^{\circ} \mathrm{W}$, 30.IV.2004, R. P. Webster, mixed forest, m.v. light (1 9 , RWC).

Collection and habitat data. Smetana (1976) reported this species from moss, mushrooms, and deciduous leaf litter (birch and poplar stands) near streams. In the Alberta foothills forests, Q. labradorensis was considered to be an open-ground specialist after forest harvesting and only extended a short distance into adjacent uncut forests (Pohl et al. (2007). Numbers of this species also increased after harvesting. In New Brunswick, most adults were found in old-growth eastern white cedar swamps in moss usually near small streams. One adult was found under white-tailed deer (Odocoileus virginianus (Zimmerman)) dung, and another was collected at a mercury-vapor light. Adults were collected during April and May.

Distribution in Canada and Alaska. AK, BC, NT, AB, MB, ON, QC, NB, NF (Smetana 1971a, 1973, 1976, 1978). Majka et al. (2011) listed this species as occurring in New Brunswick without any supporting references or data. Here, we provide the first documented records from New Brunswick.

\section{Quedius (Quedionuchus) plagiatus Mannerheim, 1843}

http://species-id.net/wiki/Quedius_plagiatus

Map 21

Material examined. Additional New Brunswick records, Albert Co., Caledonia Gorge P.N.A., $45.8257^{\circ} \mathrm{N}, 64.7791^{\circ} \mathrm{W}, 6$.VII.2011, R. P. Webster, old hardwood forest (sugar maple and beech), under bark of sugar maple log $(1, \mathrm{NBM})$. Carleton Co., Hovey Hill P.N.A., $46.1115^{\circ} \mathrm{N}, 67.7770^{\circ} \mathrm{W}, 19 . \mathrm{VIII} .2004$, R. P. Webster, hardwood forest, under bark of log (1 q, RWC); Jackson Falls, Bell Forest, $46.2200^{\circ}$ N, $67.7231^{\circ} \mathrm{W}, 4-12 . V I .2008$, R. P. Webster, mature hardwood forest, Lindgren funnel trap (1, AFC); same locality, 14-20.V.2009, 16-21.VI.2009 , R. P. Webster \& M.-A. Giguère, mature hardwood forest, Lindgren funnel traps (2, AFC). Charlotte Co., $5.1 \mathrm{~km} \mathrm{NW}$ of Pomeroy Ridge, $45.3055^{\circ} \mathrm{N}, 67.4340^{\circ} \mathrm{W}$, 
5.VI.2008, R. P. Webster, mixed forest, under bark of spruce log (1, NBM); $10 \mathrm{~km} \mathrm{NW}$ of New River Beach, $45.2110^{\circ} \mathrm{N}, 66.6170^{\circ} \mathrm{W}, 30 . \mathrm{IV}-17 . V .2010$, R. Webster \& V. Webster, coll., old growth eastern white cedar forest, Lindgren funnel trap (1, AFC). Queens Co., Cranberry Lake P.N.A., 46.1125N, 65.6075W, 24.IV-5 V.2009, 21-27.V.2009, 5-11. VI.2009, 18-25.VI.2009, 25.VI-1 VII.2009, 21-28.VII.2009, 6-14.VIII.2009, R. Webster \& M.-A. Giguère, mature red oak forest, Lindgren funnel traps $(2+13$ sex undetermined, AFC, NBM, RWC). Restigouche Co., Little Tobique River near Red Brook, $47.4462^{\circ} \mathrm{N}$, $67.0689^{\circ} \mathrm{W}, 24 . \mathrm{V} .2007$, R. P. Webster, old-growth eastern white cedar forest, under bark of large fallen spruce ( 1 \%, NBM); Jacquet River Gorge P.N.A., $47.8200^{\circ} \mathrm{N}, 66.0015^{\circ} \mathrm{W}$, 13.V.2010, R. P. Webster (1, NBM); same locality but $47.8257^{\circ} \mathrm{N}, 66.0779^{\circ} \mathrm{W}, 14 . \mathrm{V} .2010$, P. Giasson, old mixed forest, under bark of Populus sp. log (1, NBM); South Branch Rd., 494 m elev., $47.8767^{\circ} \mathrm{N}, 68.2657^{\circ} \mathrm{W}, 22 . \mathrm{VI} .2010$, R. P. Webster, Spruce and balsam fir forest, under bark of spruce (1, NBM); Dionne Brook P.N.A., $47.9030^{\circ} \mathrm{N}, 68.3503^{\circ} \mathrm{W}, 28 . \mathrm{VII}-$ 9.VIII.2011, M. Roy \& V. Webster, old-growth northern hardwood forest, Lindgren funnel trap (2, AFC, NBM); same locality and collectors but $47.9064^{\circ} \mathrm{N}, 68.3441^{\circ} \mathrm{W}, 15-27$. VI.2011, old-growth white spruce and balsam fir forest, Lindgren funnel traps (2, AFC, NBM). Sunbury Co., Acadia Research Forest, 45.9866 N, 66.3841 W, 6-24.VI.2009, 13 21.VII.2009, 21-29.VII.2009, 29.VII-4.VIII.2009, R. Webster \& M.-A. Giguère, mature (100 year-old) red spruce forest with scattered red maple and balsam fir, Lindgren funnel trap

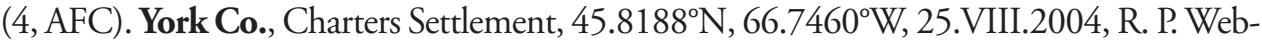
ster, clear-cut, under bark of conifer stump ( $3 \mathrm{O}^{\top}, 3$ ㅇ, RWC); same locality but, $45.8380^{\circ} \mathrm{N}$, $66.7310^{\circ} \mathrm{W}, 14 . \mathrm{V} .2004$, R. P. Webster, mixed forest, under bark of conifer (1 9 , RWC); 15

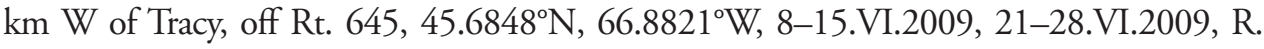
Webster \& M.-A. Giguère, mature (120-180 year-old) red pine forest, Lindgren funnel traps (4, AFC); $14 \mathrm{~km} \mathrm{WSW} \mathrm{of} \mathrm{Tracy,} \mathrm{S} \mathrm{of} \mathrm{Rt.} \mathrm{645,} \mathrm{45.6741}{ }^{\circ} \mathrm{N}, 66.8661^{\circ} \mathrm{W}, 26 . \mathrm{IV}-10 . \mathrm{V} .2010$, R. Webster \& C. MacKay, old mixed forest with red and white spruce, red and white pine, balsam fir, eastern white cedar, red maple, and Populus sp., Lindgren funnel trap (1, AFC).

Collection and habitat data. This common Holarctic species is found under bark of dead trees, usually coniferous species (Smetana 1971a). In New Brunswick, most specimens were found under bark of conifer logs or stumps and some under bark of hardwoods. Adults were also commonly captured in Lindgren funnel traps. Adults were collected in April, May, June, July, and August.

Distribution in Canada and Alaska. AK, YT, NT, BC, AB, SK, MB, ON, QC, NB, NS (Smetana 1971a; Bishop et al. 2009). Quedius plagiatus was listed as occurring in New Brunswick by Majka et al. (2011) without any supporting references or data. Here, we provide the first documented records from New Brunswick.

\section{Quedius (Distichalius) capucinus (Gravenhorst, 1806)}

http://species-id.net/wiki/Quedius_capucinus

Map 22

Material examined. New Brunswick, Queens Co., Cranberry Lake P.N.A., $46.1125^{\circ} \mathrm{N}$, 65.6075 ${ }^{\circ} \mathrm{W}, 10-11 . V I I .2009$, R. Webster \& M.-A. Giguère, mature red oak forest, 
u.v. light $\left(2\right.$ ${ }^{\lambda}, 1$ q, AFC). Restigouche Co., Dionne Brook P.N.A., $47.9030^{\circ} \mathrm{N}$, 68.3503 W, 14-28.VII.2011, 28.VII-9.VIII.2011, M. Roy \& V. Webster, old-growth northern hardwood forest, Lindgren funnel traps (2, AFC, NBM). York Co., Charters Settlement, $45.8430^{\circ} \mathrm{N}, 66.7275^{\circ} \mathrm{W}, 14 . I X .2004,17 . I X .2004$, 25.IX.2004, 6.X.2005, R. P. Webster, regenerating mixed forest, baited with pile of decaying mushrooms (1 O, 5 ㅇ, NBM, RWC); same locality but $45.8286^{\circ} \mathrm{N}, 66.7365^{\circ} \mathrm{W}, 24 . \mathrm{VI} .2006$, R. P. Webster, mature mixed forest, in gilled mushroom ( $1 \hat{0}$, RWC); same locality but $45.8395^{\circ} \mathrm{N}, 66.7391^{\circ} \mathrm{W}, 28 . I X .2006,29 . V I I I .2007$, R. P. Webster, mixed forest, in pile of corncobs and cornhusks ( $1 \hat{\jmath}, 1$, RWC).

Collection and habitat data. This species appears to prefer decaying organic substances and has been found on carrion, under human feces (Smetana 1971a), and in fleshy fungi (Blatchley 1910). In New Brunswick, most specimens were found in decaying mushrooms and compost (pile of corncobs and cornhusks). Two individuals were captured in Lindgren funnel traps deployed in an old-growth northern hardwood forest. Adults were found in April, June, July, August, September, and October.

Distribution in Canada and Alaska. ON, QC, NB, NS (Smetana 1971a; Bishop et al. 2009).

Quedius (Distichalius) cinctus (Paykull, 1790)

http://species-id.net/wiki/Quedius_cinctus

Map 23

Material examined. Additional New Brunswick records. Restigouche Co., Mount Atkinson, $447 \mathrm{~m}$ elev., $47.8192^{\circ} \mathrm{N}, 68.2618^{\circ} \mathrm{W}, 21 . V I I .2010$, R. P. Webster, spruce and balsam fir forest (boreal forest), small shaded spring-fed brook with mossy margin, in wet moss ( $1 \mathrm{O}^{\mathrm{N}}$, RWC). York Co., Charters Settlement, $45.8430^{\circ} \mathrm{N}, 66.7275^{\circ} \mathrm{W}$, 8.X.2004, 6.X.2005, R. P. Webster, regenerating mixed forest, baited with pile of decaying mushrooms $\left(1 \mathrm{\delta}, 3\right.$ q, NBM, RWC); Charters Settlement, $45.8395^{\circ} \mathrm{N}$, 66.7391 ${ }^{\circ} \mathrm{W}, \quad$ 18.X.2004， 6.IX.2005， 5.VIII.2005， 29.III.2006， 17.IX.2006, 26.IX.2007, R. P. Webster, mixed forest, in pile of decaying (moldy) corncobs and cornhusks (4 ô, 3 क , NBM, RWC); same locality data and collector but 17.IX.2006, mixed forest, in pile of decaying leaves ( $1 \hat{\partial}$, RWC).

Collection and habitat data. In Europe, Q. cinctus usually occurs in decaying organic material, usually near human settlements (Smetana 1971a). In New Brunswick, specimens were similarly found in decaying organic material (decaying mushrooms, decaying corncobs and cornhusks, decaying leaves). One individual was found in wet moss along a cold, shaded brook. Adults were collected in April, July, September, and October.

Distribution in Canada and Alaska. ON, NB (Majka et al. 2009; Brunke and Marshall 2011). This adventive species was first reported from New Brunswick and Canada by Majka et al. (2009) from three specimens collected from a domestic pig carcass in Bouctouche (Kent Co.) in 2007. This species is probably well established in 
New Brunswick and likely occurs in the intervening areas between this province and Massachusetts (Framingham and Fall River, USA), where the species was first reported by Smetana (1971a) from North America.

\section{Quedius (Raphirus) frigidus Smetana, 1971**}

http://species-id.net/wiki/Quedius_frigidus

Map 24

Material examined. New Brunswick, Restigouche Co., Berry Brook P.N.A., $47.8140^{\circ} \mathrm{N}, 66.7578^{\circ} \mathrm{W}, 26 . \mathrm{V} .2007$, R. P. Webster, old-growth eastern white cedar forest in moss and leaf litter near brook ( $4 \hat{\sigma}, 4$,, NBM, RWC); MacFarlane Brook P.N.A., $47.6018^{\circ} \mathrm{N}, 67.6263^{\circ} \mathrm{W}, 25 . V .2007$, R. P. Webster, old growth eastern white cedar forest in moss near brook ( $\left.4 \mathrm{O}^{\top}, \mathrm{NBM}, \mathrm{RWC}\right)$; Mount Atkinson, $447 \mathrm{~m}$ elev., $47.8192^{\circ} \mathrm{N}, 68.2618^{\circ} \mathrm{W}, 23 . V I .2010$, R. P. Webster, spruce and balsam fir forest (boreal forest), small, shaded, spring-fed brook with mossy margin, in wet moss ( $1 \hat{\jmath}$, RWC).

Collection and habitat data. Relatively little was previously known about the habitat requirements of this species, although it appears that this species may be associated with moss and leaf litter near small streams and other wetlands. Smetana $(1973,1976)$ reported the species from leaf litter in a sphagnum bog, wet sphagnum (treading) along the margin of a large spring, and in leaf litter (sifting) along a small stream. In the Alberta Foothills forests, Q. frigidus was considered to be a mature forest specialist (Pohl et al. 2007). Adults at the three New Brunswick localities were found in moss and leaf litter near brooks in old-growth eastern white cedar forests and a mature spruce and balsam fir forest on the north-facing slope of a hill. Adults were collected during May and June.

Distribution in Canada and Alaska. AK, NT, ON, NB, NF (Smetana 1973, $1976,1978,1981)$. Smetana (1971a, 1973) suggested that Q. frigidus was a northern transcontinental species with glacial relic populations in southern areas at higher mountain elevations. The New Brunswick records indicate a more southerly distribution at low elevations in eastern Canada.

\section{Quedius (Raphirus) fulvicollis (Stephens, 1833)**}

http://species-id.net/wiki/Quedius_fulvicollis

Map 25

Material examined. New Brunswick, Albert Co., Caledonia Gorge P.N.A., $45.8176^{\circ} \mathrm{N}, 64.7800^{\circ} \mathrm{W}, 6 . \mathrm{VII} .2011$, R. P. Webster, old hardwood forest (sugar maple and beech), in mossy seepage area with Carex, sifting moss and grass litter $\left(2 \delta^{\lambda}, 1\right.$, NBM, RWC). Restigouche Co., $7.5 \mathrm{~km} \mathrm{~S}$ of Saint Arthur, $47.8283^{\circ} \mathrm{N}, 66.7654^{\circ} \mathrm{W}$, 14.VI.2006, R. P. Webster, old-growth eastern white cedar forest, in moist leaves at base of large white birch (1 $\mathrm{N}$, RWC). York Co., Charters Settlement, $45.8395^{\circ} \mathrm{N}$, $66.7391^{\circ} \mathrm{W}, 19 . \mathrm{V} .2005$, R. P. Webster, alder swamp, in moist leaf litter near small 


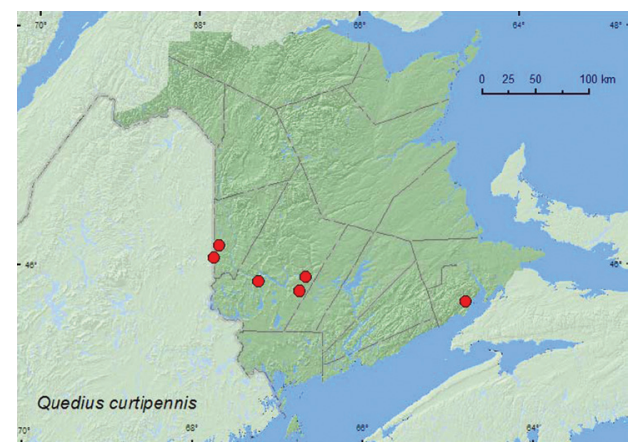

Map 19. Collection localities in New Brunswick, Canada of Quedius curtipennis.

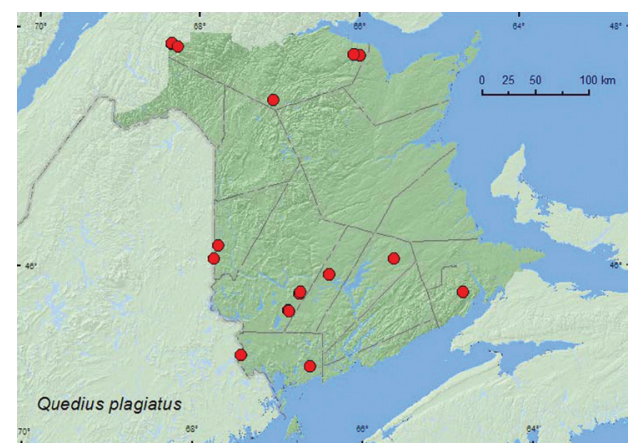

Map 2I. Collection localities in New Brunswick, Canada of Quedius plagiatus.

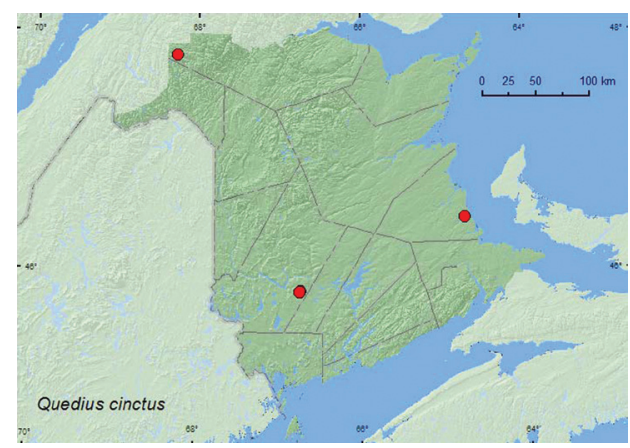

Map 23. Collection localities in New Brunswick, Canada of Quedius cinctus.

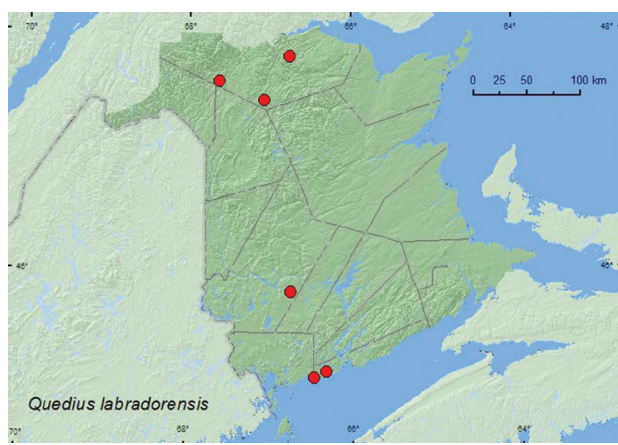

Map 20. Collection localities in New Brunswick, Canada of Quedius l. labradorensis.

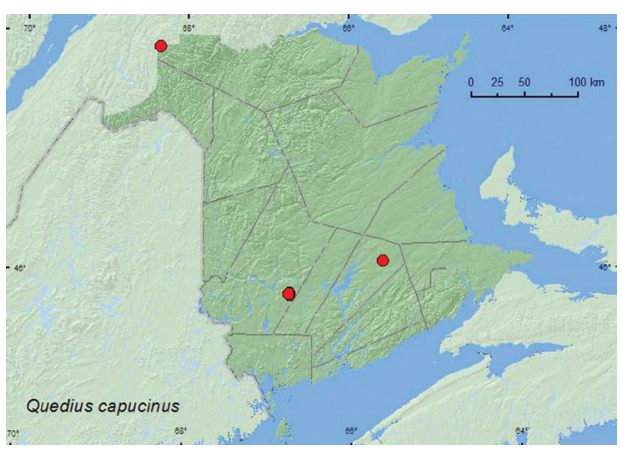

Map 22. Collection localities in New Brunswick, Canada of Quedius capucinus.

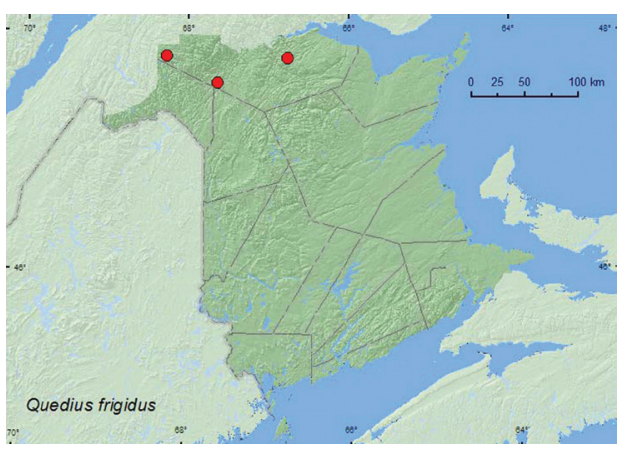

Map 24. Collection localities in New Brunswick, Canada of Quedius frigidus.

(slow flowing) brook ( 1 O , RWC); Mazerolle Settlement, $45.8717^{\circ} \mathrm{N}, 66.8273^{\circ} \mathrm{W}$, 28.IV.2006, R. P. Webster, eastern white cedar swamp, in moss and leaf litter near brook (1 9 , RWC); $8 \mathrm{~km} \mathrm{NW}$ of Magundy, $45.8712^{\circ} \mathrm{N}, 67.2221^{\circ} \mathrm{W}, 8$. VII.2006, R. P. Webster, mature hardwood forest, margin of small cold (spring-fed) brook among sedges $(1 \hat{\jmath}, 2$, , RWC). 
Collection and habitat data. Adults of this species occur in moist moss, sphagnum, deciduous leaf litter, and mixed forest litter in various wet biotypes such as small stream margins, lake margins, and wet areas in forests (Smetana 1971a, 1973, 1976). In New Brunswick, most specimens were found in moist leaf litter, moss, or among sedges near small brooks in alder swamps, eastern white cedar forests, and hardwood forests. Adults were collected during April, May, June, and July.

Distribution in Canada and Alaska. AK, YT, BC, AB, MB, ON, QC, NB, NF (Smetana 1971a, 1973, 1976).

Quedius (Raphirus) simulator Smetana, 1971**

http://species-id.net/wiki/Quedius_simulator

Map 26

Material examined. New Brunswick, Restigouche Co., Mount Atkinson, $447 \mathrm{~m}$ elev., $47.8192^{\circ} \mathrm{N}, 68.2618^{\circ} \mathrm{W}, 21 . V I I .2010$, R. P. Webster, spruce and balsam fir forest (boreal forest), small, shaded, spring-fed brook with mossy margin, in wet moss (1 O, RWC); Jacquet River Gorge P.N.A., $47.8109^{\circ} \mathrm{N}, 66.0905^{\circ} \mathrm{W}, 13$. VIII.2010, R. P. Webster, old mixed forest, small shaded spring-fed brook with mossy margin, in wet moss ( 1 o , 2 ㅇ, RWC).

Collection and habitat data. This species was reported from very wet debris and moss in small gullies and depressions on the forest floor and edges of oligotrophic ponds in mixed forests, and from Carex hummocks and wet debris from various wet habitats such as lake margins, swamps, and marshes (Smetana 1971, 1973). Specimens from Moosonee, Ontario were collected by sifting leaf litter under willow (Salix sp.) and alder bushes near the Moose River (Smetana 1976). In New Brunswick, adults were found in wet moss along shaded, cold, spring-fed brooks. Adults were collected during July and August.

Distribution in Canada and Alaska. AK, NT, BC, AB, SK, MB, ON, QC, NB, LB (Smetana 1971a, 1973, 1976, 1981, 1990). This is a northern transcontinental species, with most records from the boreal forest of northern Canada (Smetana 1971a, 1973, 1976, 1981).

\section{Subtribe Staphylinina Latreille, 1802}

Staphylinus ornaticauda LeConte, 1863

http://species-id.net/wiki/Staphylinus_ornaticauda

Map 27

Material examined. New Brunswick, Charlotte Co., $3 \mathrm{~km} \mathrm{SW}$ of King Brook Lake, $45.3194^{\circ} \mathrm{N}, 67.4414^{\circ} \mathrm{W}, 27 . V .2007$, R. P. Webster, eastern white cedar, red maple, and black ash swamp, in moist litter and moss near small pools with Carex (2 $\mathrm{O}^{\mathrm{O}}$, 
1 q, RWC); $3.5 \mathrm{~km} \mathrm{NW}$ of Pomeroy Ridge, $45.3087^{\circ} \mathrm{N}, 67.4362^{\circ} \mathrm{W}, 5 . \mathrm{VI} .2008$, 16.VI.2008, R. P. Webster, red maple swamp, in leaves and moss near small vernal pool with Carex (1 Õ, 2 \&, NBM). Northumberland Co., Goodfellow Brook P.N.A., $46.8943^{\circ} \mathrm{N}, 65.3796^{\circ} \mathrm{W}, 23 . V .2007$, R. P. Webster, old-growth eastern white cedar swamp, in moss and litter on hummock (2 $\mathrm{O}^{\lambda}$, RWC). York Co., Canterbury, "Browns Mountain Fen”, $45.8967^{\circ} \mathrm{N}, 67.6343^{\circ} \mathrm{W}, 2$.V.2005, 29.IV.2006, M.-A. Giguère \&

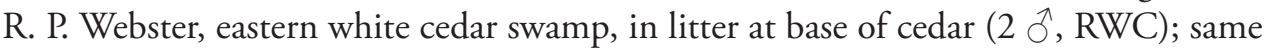
locality but $45.8957^{\circ} \mathrm{N}, 67.6462^{\circ} \mathrm{W}, 29 . I V .2006$, R. P. Webster, eastern white cedar swamp in sphagnum and litter near vernal pool with Carex (1 Oे $^{1} 1$ \%, RWC).

Collection and habitat data. Brunke et al. (2011) reported that Staphylinus ornaticauda was restricted to wetlands, such as bogs and fens, with an abundance of sphagnum moss. In New Brunswick, this species appears to be associated with eastern white cedar swamps and fens and red maple swamps on calcareous soils. Adults were collected in eastern white cedar swamps, an eastern white cedar, red maple, and black ash (Fraxinus nigra Marsh.) swamp, and in a red maple swamp near an eastern white cedar swamp. Adults occurred in litter at the base of cedars, and in moist litter and moss near small vernal pools with Carex. Adults were collected by sifting litter. This species was collected in April, May, and June. This species is flightless (Brunke et al. 2011). Due to the limited dispersal capabilities, restricted habitat requirements, and apparent rarity, Brunke et al. (2011) suggested that this species should be studied as a potential species at risk.

Distribution in Canada and Alaska. MB, ON, PQ, NB, NS (Campbell and Davies 1991, as Staphylinus erythropterus Linnaeus).

\section{Subtribe Philonthina Kirby, 1837}

\section{Bisnius cephalicus Casey, 1915**}

http://species-id.net/wiki/Bisnius_cephalicus

Map 28

Material examined. New Brunswick, Restigouche Co., $7.5 \mathrm{~km} \mathrm{~S}$ of Saint Arthur, $47.8283^{\circ} \mathrm{N}, 66.7654^{\circ} \mathrm{W}, 14 . V I .2006$, R. P. Webster, old-growth eastern white cedar forest in moist leaves at base of large white birch ( 10,1 ㅇ, NBM, RWC); Berry Brook P.N.A., $47.8140^{\circ} \mathrm{N}, 66.7578^{\circ} \mathrm{W}, 26 . V .2007$, R. P. Webster, old-growth eastern white cedar swamp, in moss and leaf litter under alders ( 1 Oे, 1 \%, RWC); MacFarlane Brook P.N.A., $47.6018^{\circ} \mathrm{N}, 67.6263^{\circ} \mathrm{W}, 25 . V .2007$, R. P. Webster, old-growth eastern white cedar swamp, in moss and leaves under alders near brook ( 1 ,, $\mathrm{RWC})$; Jacquet River Gorge P.N.A., $47.8204^{\circ} \mathrm{N}, 66.0833^{\circ} \mathrm{W}, 14 . \mathrm{VI} .2008$, R. P. Webster, river margin in drift material (1 $\hat{\jmath}$, RWC).

Collection and habitat data. Little was previously known about the habitat requirements of this species. In New Brunswick, this species was found in leaf litter and moss near brooks in old-growth eastern white cedar forests and in drift material along a river margin (1). Adults were collected in May and June. 
Distribution in Canada and Alaska. AB, MB, ON, NB (Smetana 1995). This species was previously known from only three specimens from two localities, a single female from the type locality at "Aweme", Manitoba and two specimens from George Lake, Alberta (Smetana 1995) Recently, Brunke and Marshall (2011) reported another specimen of this species from N. Moosonee, Ontario.

\section{Bisnius cephalotes (Gravenhorst, 1802)}

http://species-id.net/wiki/Bisnius_cephalotes

Remarks. Bisnius cephalotes was reported by Majka and Klimaszewski (2008a) from New Brunswick based on three specimens collected by R. P. Webster from New Maryland. There are no specimens of this species in the collections of R. P. Webster or C. Majka from New Brunswick. This species is, therefore, removed from the faunal list of New Brunswick.

\section{Bisnius palmi Smetana, 1955}

http://species-id.net/wiki/Bisnius_palmi

Map 29

Material examined. New Brunswick, Queens Co., near Quarries, $45.6005^{\circ} \mathrm{N}$, $66.0500^{\circ} \mathrm{W}, 25 . \mathrm{IX} .2006$, S. Makepeace, contents from barred owl nest box, $8 \mathrm{~m}$ high on red maple (1, ᄋ, RWC); $4 \mathrm{~km} \mathrm{~W}$ of Lower Gagetown, $45.7466^{\circ} \mathrm{N}, 66.1862^{\circ} \mathrm{W}, 30$.VII.2006, $\mathrm{S}$. Makepeace, mixed red oak and pine forest, contents of red shouldered hawk nest $12 \mathrm{~m}$ high in red oak (3 $\partial^{\lambda}, 2$ \%, RWC); Pleasant Villa, $45.7023^{\circ} \mathrm{N}, 66.1732^{\circ} \mathrm{W}, 15 . V I .2007$, S. Makepeace \& R. Webster (1,, , NBM); Rees, near Grand Lake, $46.0016^{\circ} \mathrm{N}, 65.9466^{\circ} \mathrm{W}$, 29.V.2007, S. Makepeace \& R. Webster, nest box contents of barred owl (4 $0^{\lambda}, 6$ + $\mathrm{NBM}$, RWC); McAlpines near Upper Hampstead Rd., $45.7250^{\circ} \mathrm{N}, 66.1200^{\circ} \mathrm{W}, 3 . V I .2007$, S. Makepeace \& R. Webster, nest contents of barred owl (1 $\delta^{\lambda}, 1$ \&, NBM); Cranberry Lake P.N.A., $46.1125^{\circ} \mathrm{N}, 65.6075^{\circ} \mathrm{W}, 7-22 . V I .2011,13-20 . V I I .2011$, M. Roy \& V. Webster, old red oak forest, Lindgren funnel traps in forest canopy $(2 \hat{\sigma}$, NBM). Sunbury Co., Noonan, $45.9923^{\circ} \mathrm{N}, 66.4099^{\circ} \mathrm{W}, 2 . V I .2007$, S. Makepeace \& R. P. Webster, nest contents of barred owl from tree hole $7 \mathrm{~m}$ high in red maple (1 +, NBM). Westmorland Co., Sackville, near Ogden Mill, 45.9216N, 64.3893W, 12.V.2006, S. Makepeace, black spruce forest, in nest contents of great horned owl, Bubo virginianus (2 +, NBM, RWC). York Co., Graham Corner, $45.8565^{\circ} \mathrm{N}, 67.7083^{\circ} \mathrm{W}, 26 . V I .2007$, S. Makepeace \& R. Webster, nest contents of barred owl from tree hole in sugar maple (1 $\mathrm{O}^{\mathrm{N}}, 1$ ㅇ, NBM); Marysville, $45.9750^{\circ} \mathrm{N}, 66.5700^{\circ} \mathrm{W}, 22 . V I .2007$, S. Makepeace \& R. Webster, nest box contents of barred owl ( 1 ,, $\mathrm{NBM})$.

Collection and habitat data. This species was reported by Smetana (1995) from various habitats associated with trees, such as swallow nests, old squirrel nests, and a red oak tree fork hole. In New Brunswick, all but one of the B. palmi specimens were found in the nest contents of a great horned owl (Bubo virginianus Gmelin) and barred 
owls, which normally nest in tree holes or in artificial nest boxes on trees. This species was also found in the nest contents of a red shouldered hawk (Buteo lineatus Gmelin), which makes large nests within forks of large trees. One adult was captured in a Lindgren funnel trap deployed in the canopy of a red oak in an old red oak forest. Adults were collected in May, June, July, and September.

Distribution in Canada and Alaska. ON, NB, NS (Smetana 1995). Bisnius palmi is transcontinental in North America, with most records from eastern North America. There is one record from Nova Scotia (Caribou Island). Bisnius palmi was originally described from Sicily, Italy, but was apparently an accidental, introduced specimen (Smetana 1995).

\section{Bisnius quediinus Horn, 1884**}

http://species-id.net/wiki/Bisnius_quediinus

Map 30

Material examined. New Brunswick, Queens Co., Cranberry Lake P.N.A., $46.1125^{\circ} \mathrm{N}, 65.6075^{\circ} \mathrm{W}, 21-27 . V .2009$, R. Webster \& M.-A. Giguère, mature red oak forest, Lindgren funnel traps ( 2 , 1 sex undetermined, AFC, RWC); Grand

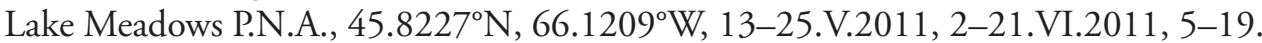
VII.2011, M. Roy \& V. Webster, old silver maple forest and seasonally flooded marsh, Lindgren funnel traps (3, AFC, NBM, RWC). Restigouche Co., Dionne Brook P.N.A., $47.9030^{\circ} \mathrm{N}, 68.3503^{\circ} \mathrm{W}, 27 . \mathrm{VI}-14 . V I I .2011$, M. Roy \& V. Webster, oldgrowth northern hardwood forest, Lindgren funnel trap (1, NBM). Sunbury Co., Acadia Research Forest, $45.9866^{\circ} \mathrm{N}, 66.3841^{\circ} \mathrm{W}, 28 . I V-4 . V .2009,25 . V-2 . V I .2009, \mathrm{R}$. Webster \& M.-A. Giguère, mature (100 year-old) red spruce forest with scattered red maple and balsam fir, Lindgren funnel traps ( 1 ${ }^{\lambda}, 1$ sex undetermined, AFC, RWC). York Co. New Maryland, off Hwy 2, E of Baker Brook, $45.8760^{\circ} \mathrm{N}, 66.6252^{\circ} \mathrm{W}$, 6.IV.2005, R. P. Webster, old growth eastern white cedar swamp, in moss and litter at base of cedar $\left(1 \mathrm{O}^{\lambda}, 1\right.$ \%, RWC); $15 \mathrm{~km} \mathrm{~W}$ of Tracy, off Rt. $645,45.6848^{\circ} \mathrm{N}$, 66.8821 ${ }^{\circ} \mathrm{W}, 4-11 . V .2009,11-19 . V .2009,28 . V I-7 . V I I .2009$, R. Webster \& M.-A. Giguère, mature (120- 180 year-old) red pine forest, Lindgren funnel traps (1 9,2 sex undetermined, AFC, RWC); Charters Settlement, $45.8395^{\circ} \mathrm{N}, 66.7391^{\circ} \mathrm{W}, 16-$ 23.V.2009, R. P. Webster, mixed forest, Lindgren funnel trap (1 $\delta^{\lambda}$, RWC).

Collection and habitat data. Little is known about the habitat associations of this species. Smetana (1995) speculated that it might live in burrows of mammals or, less likely, in bird nests. Two specimens from New Brunswick were found in moss at the base of a tree in an old-growth eastern white cedar swamp early in the season when some snow and ice were still present. This was possibly an overwintering site. Most specimens were captured in Lindgren funnel traps deployed in a variety of forest types (red pine, red oak, red spruce, mixed forest, old-growth northern hardwood forest). These traps mimic tree trunks (Lindgren 1983), and it is possible that this species lives in microhabitats associated with standing trees. Adults were collected in April, May, June, and July. 
Distribution in Canada and Alaska. QC, NB (Smetana 1995). This rare species was known from only a few localities in Quebec south to Massachusetts and west to Michigan, Kansas, and South Dakota (Smetana 1995).

\section{Erichsonius alumnus Frank, 1975**}

http://species-id.net/wiki/Erichsonius_alumnus

Map 31

Material examined. New Brunswick, Charlotte Co., ca. 9 km NW of New River, $45.2067^{\circ} \mathrm{N}, 66.6505^{\circ} \mathrm{W}, 13 . \mathrm{VI} .2008$, R. P. Webster, alder swamp near large brook, treading vegetation along brook margin $(1$ \& NBM). Restigouche Co., Little Tobique River near Red Brook, $47.4465^{\circ} \mathrm{N}, 67.0689^{\circ} \mathrm{W}, 13 . V I .2006$, R. P. Webster, river margin, under debris on clay and sand mix ( $3 \curvearrowright, 5$ sex undetermined, RWC). York Co., Charters Settlement, $45.8404^{\circ} \mathrm{N}, 66.7360^{\circ} \mathrm{W}, 27 . V .2008$, R. P. Webster, brook margin partially shaded by alders, among cobblestones and gravel ( $1 \hat{0}$, RWC); near Mazerolle Settlement, N of Hwy 2 near exit 271, $45.8764^{\circ} \mathrm{N}, 66.8260^{\circ} \mathrm{W}, 7 . \mathrm{VI} .2008$, R. P. Webster, brook margin in beaver meadow, in fine gravel/clay mixed with grass (1 ${ }^{\lambda}$, RWC); $8.4 \mathrm{~km} \mathrm{~W}$ of Tracy, off Rt. $645,45.6821^{\circ} \mathrm{N}, 66.7894^{\circ} \mathrm{W}, 14 . \mathrm{V} .2008$, R. P. Webster, alder swamp near brook, in leaf litter and grass on hummock (1, NBM).

Collection and habitat data. Erichsonius alumnus appears to be a riparian species associated with river and brook margins. Records in Frank (1975) included individuals from banks of streams, on mud by a brook, and an individual collected by treading mud by a stream. In New Brunswick, the largest series was collected along a river margin under debris on a sand-clay mix. Other adults were collected from brook margins in alder swamps and a beaver meadow. Adults occurred in grass litter mixed with fine gravel and clay, among cobblestones and gravel, and leaf and grass litter from these brook margin habitats. This species was collected in May and June.

Distribution in Canada and Alaska. ON, QC, NB (Frank 1975).

Erichsonius inutilis (Horn, 1884)**

http://species-id.net/wiki/Erichsonius_inutilis

Map 32

Material examined. New Brunswick, Queens Co., W of Jemseg at "Trout Creek", $45.8231^{\circ} \mathrm{N}, 66.1245^{\circ} \mathrm{W}, 11 . I V .2006$, R. P. Webster, silver maple swamp, sifting leaf litter from crotch of silver maple with multiple trunks ( $1 \hat{\delta}, 1$ sex undetermined, RWC); near Queenstown, $45.6904^{\circ} \mathrm{N}, 66.1455^{\circ} \mathrm{W}, 13 . \mathrm{V} .2008$, R. P. Webster, old hardwood forest, in leaf litter in seepage area near small brook ( $2 \hat{\partial}, 1$ sex undetermined, RWC); ca. $3.5 \mathrm{~km} \mathrm{~W}$ of Lower Gagetown, $45.7497^{\circ} \mathrm{N}, 66.1846^{\circ} \mathrm{W}, 13 . \mathrm{V} .2008$, R. P. Webster, mature red oak and red maple forest, in moist leaves on margin of vernal pond (1, RWC). York Co., Mazerolle Settlement, $45.8729^{\circ} \mathrm{N}, 66.8311^{\circ} \mathrm{W}, 28 . I V .2006$, R. 


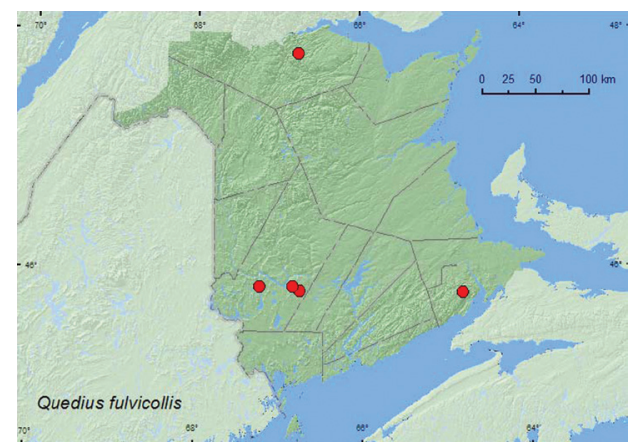

Map 25. Collection localities in New Brunswick, Canada of Quedius fulvicollis.

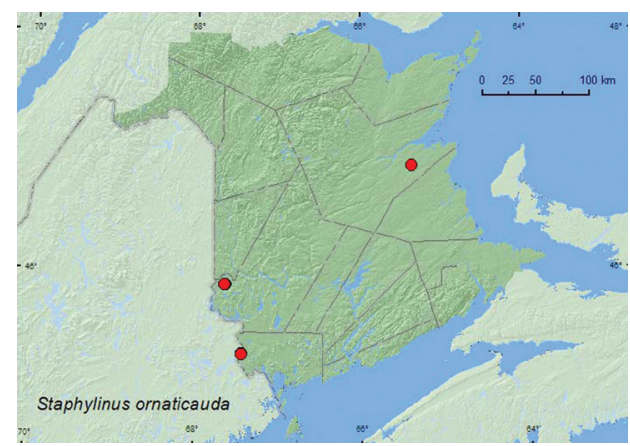

Map 27. Collection localities in New Brunswick, Canada of Staphylinus ornaticuada.

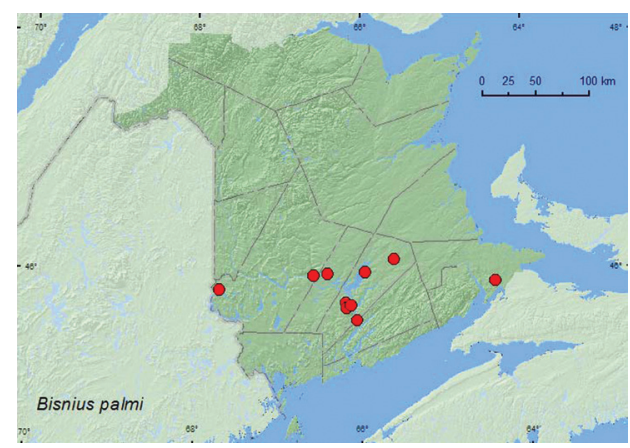

Map 29. Collection localities in New Brunswick, Canada of Bisnius palmi.

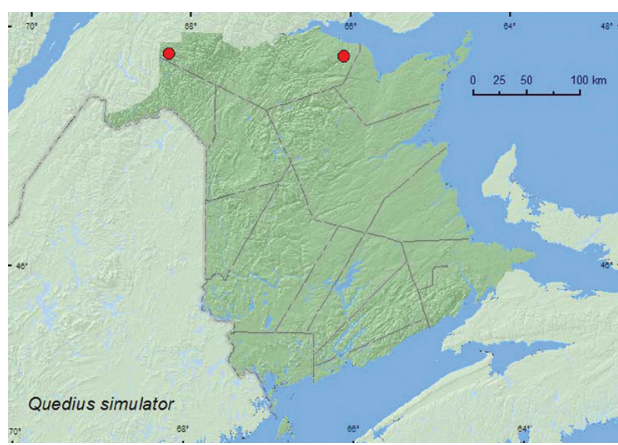

Map 26. Collection localities in New Brunswick, Canada of Quedius simulator.

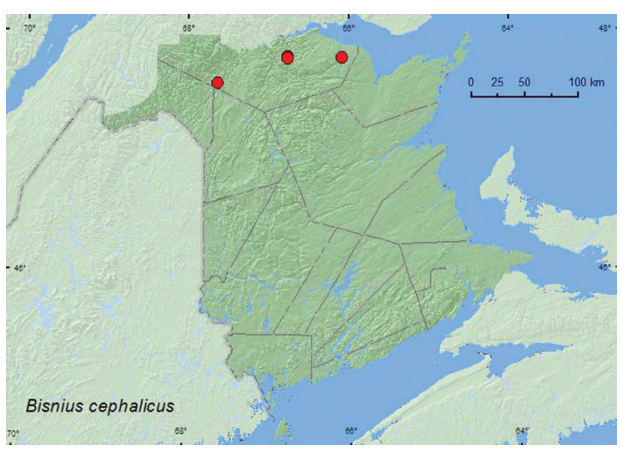

Map 28. Collection localities in New Brunswick, Canada of Bisnius cephalicus.

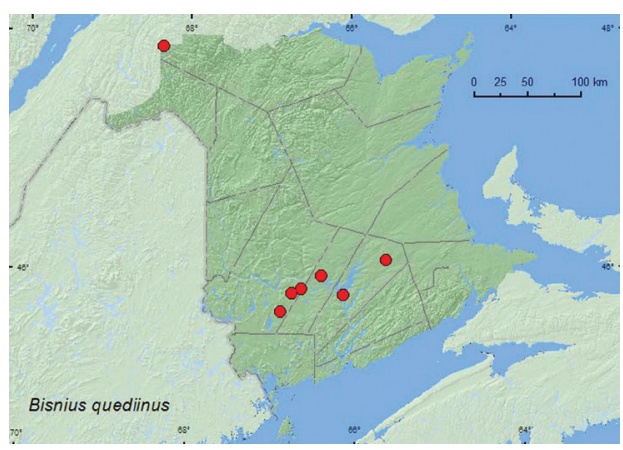

Map 30. Collection localities in New Brunswick, Canada of Bisnius quediinus.

P. Webster, stream margin (sun-exposed), in grass litter on muddy soil (1 $\hat{\jmath}, \mathrm{RWC})$; Kelly's Creek at Sears Road, $45.8723^{\circ}$ N, $66.8414^{\circ} \mathrm{W}, 7 . V I .2008$, R. P. Webster, Carex marsh, treading ( 1 đ , RWC); Fredericton at Saint John River, $45.9598^{\circ} \mathrm{N}, 66.6258^{\circ} \mathrm{W}$, 19.VII.2005, R. P. Webster, river margin, under drift material (1, RWC). 
Collection and habitat data. Little was previously known about the habitat associations of this species. The only records with habitat data reported in Frank (1975) included specimens sifted from flood debris, swamp grass, ex nest of a meadow vole (Microtus pennsylvanicus Ord), and one individual collected in a tamarack bog. In New Brunswick, this species appears to be associated with moist to wet habitats in forested areas, including seepage areas near small brooks, vernal pond margins, stream and river margins, and Carex marsh. Adults were sifted from moist leaves, grass litter on muddy soil, drift material, and by treading Carex. A few adults were sifted from leaf litter from the crotch of a silver maple with multiple trunks in early April in a silver maple swamp. This was presumably an overwintering site for these adults. Adults were collected during April, May, June, and July.

Distribution in Canada and Alaska. ON, QC, NB (Frank 1975).

\section{Erichsonius parcus (Horn, 1884)** \\ http://species-id.net/wiki/Erichsonius_parcus \\ Map 33}

Material examined. New Brunswick, York Co., New Maryland, U.N.B. Woodlot, $45.9116^{\circ} \mathrm{N}, 66.6698^{\circ} \mathrm{W}, 26 . V .2008$, R. Webster, G. Forbes, \& M.-A. Giguère, abandoned beaver lodge occupied by muskrats, in wall of lodge ( 4 ${ }^{\top}, 2$ ㅇ, RWC).

Collection and habitat data. Little was previously known about the habitat associations of $E$. parcus. The specimens from New Brunswick were collected from the wall of an abandoned beaver lodge occupied by muskrats. In Rhode Island (USA) (Washington Co., $2 \mathrm{mi} \mathrm{S}$ of Shannock, $\left.41.4270^{\circ} \mathrm{N}, 71.6039^{\circ} \mathrm{W}, 22 . I V .2007\right)$, three specimens were sifted from moist leaves on the margin of a vernal pond (Webster, unpublished data) in a red maple swamp.

Distribution in Canada and Alaska. ON, NB (Brunke and Marshall 2011). Erichsonius parcus was reported from Massachusetts, south to Virginia, South Carolina, and Louisiana in the USA by Frank (1975).

\section{Erichsonius patella (Horn, 1884)}

http://species-id.net/wiki/Erichsonius_patella

Map 34

Material examined. New Brunswick, Queens Co., Grand Lake near Scotchtown, $45.8762^{\circ} \mathrm{N}, 66.1816^{\circ} \mathrm{W}, 25 . V .2006$, R. P. Webster, lakeshore, in drift material (1 $\mathrm{o}^{\top}$, RWC); Rees, near Grand Lake, $46.0016^{\circ} \mathrm{N}, 65.9466^{\circ} \mathrm{W}, 29$. V.2007, S. Makepeace \& R. Webster, coll., nest box contents of barred owl (1 $q$, NBMB). Sunbury Co., Acadia Research Forest, $45.9866^{\circ} \mathrm{N}, 66.3841^{\circ} \mathrm{W}, 19-25 . V .2009$, R. Webster \& M.-A. Giguère, mature (110 year-old) red spruce forest with scattered red maple and balsam fir, Lindgren funnel trap ( 1 \% , AFC). York Co., Charters Settlement, $45.8340^{\circ} \mathrm{N}, 66.7450^{\circ} \mathrm{W}$, 15.V.2004, 30.V.2004, 10.VI.2004, 27.IV.2005, R. P. Webster, mixed forest, under 
conifer bark in wood pile (4 sex undetermined, RWC); same locality and collector but $45.8300^{\circ} \mathrm{N}, 66.7360^{\circ} \mathrm{W}, 20 . \mathrm{VI} .2004$, R. P. Webster, mature mixed forest, in leaf litter near stream (1, RWC); same locality and collector but $45.8395^{\circ} \mathrm{N}, 66.7391^{\circ} \mathrm{W}$, 28.IX.2005, mixed forest, in compost (decaying vegetables) (1 $\mathrm{O}^{\lambda}$, RWC); Fredericton, Odell Park, $45.9570^{\circ} \mathrm{N}, 66.6695^{\circ} \mathrm{W}, 19 . \mathrm{VI} .2005$, R. P. Webster, in pile of woodchips and decaying plant materials ( $10^{\top}, 1$ sex undetermined, RWC); Nashwaaksis River at Rt. $105,45.9850^{\circ} \mathrm{N}, 66.6900^{\circ} \mathrm{W}, 6 . \mathrm{V} .2006$, R. P. Webster, upper river margin in flood debris (1, RWC); Kelly's Creek at Sears Road, $45.8723^{\circ} \mathrm{N}, 66.8414^{\circ} \mathrm{W}, 7 . \mathrm{VI} .2008$, R. P. Webster, alder swamp with red maple, in moist leaf and grass litter near vernal pool (1 sex undetermined, NBM); $15 \mathrm{~km} \mathrm{~W}$ of Tracy, off Rt. $645,45.6848^{\circ} \mathrm{N}, 66.8821^{\circ} \mathrm{W}$, 18.V-2.VI.2010, R. Webster \& C. MacKay, mature (120-180 year-old) red pine forest, Lindgren funnel trap (1, AFC).

Collection and habitat data. This species appears to be associated with various kinds of decaying organic materials. The few records with habitat data reported in Frank (1975) included adults collected from human dung, sifting leaves, sifting oak leaves, in ground cover in a white pine forest, ex mushrooms, funnel extract of mixed litter, Rhododendron litter, and pine-hardwood leaf litter near a stream edge. In New Brunswick, adults were found in a variety of decaying organic material, including drift material along a lakeshore, flood debris on an upper river margin, leaf litter near a stream, moist leaf and grass litter near a vernal pool, under conifer bark in a wood pile, in compost (decaying vegetables), in a pile of woodchips, and on decaying plant material. A few individuals were captured in Lindgren funnel traps. Most collections were from forested habitats. One adult was collected from the nest contents of a barred owl. Adults were collected in April, May, and June.

Distribution in Canada and Alaska. ON, QC, NB, NS (Frank 1975; Bishop et al. 2009).

\section{Erichsonius pusio (Horn, 1884)**}

http://species-id.net/wiki/Erichsonius_pusio

Map 35

Material examined. New Brunswick, York Co., Mazerolle Settlement, $45.8729^{\circ} \mathrm{N}$, 66.8311 $1^{\circ} \mathrm{W}, 28 . \mathrm{IV} .2006$, R. P. Webster, stream margin (sun exposed), in grass litter on muddy soil (1 $\hat{\gamma}, 1$ ㅇ, 2 sex undetermined, RWC); near Mazerolle Settlement, N of Hwy 2 near exit $271,45.8764^{\circ} \mathrm{N}, 66.8260^{\circ} \mathrm{W}, 7 . V I .2008$, R. P. Webster, brook margin in beaver meadow, in fine gravel/clay mixed with grass (2 $⿱ 乛 \pi, 2$ sex undetermined, RWC); Charters Settlement, $45.8395^{\circ} \mathrm{N}, 66.7391^{\circ} \mathrm{W}, 6 . V .2008$, R. P. Webster, mixed forest, in flight, collected with aerial net between 15:00 and 17:00 h (1 Ô, RWC).

Collection and habitat data. Little was previously known about the habitat associations of this species. The only records with habitat data reported in Frank (1975) included a specimen collected from a funnel extract of oak-beech leaf litter and an individual in a windrow sample. In New Brunswick, most specimens were sifted from 
grass litter on muddy soil or from litter with grass mixed with fine gravel/clay along the margins of a stream through a beaver meadow. One adult was collected with an aerial net during evening flight. Adults were collected in April, May, and June.

Distribution in Canada and Alaska. BC, ON, QC, NB (Frank 1975).

\section{Erichsonius rosellus Frank, 1975**}

http://species-id.net/wiki/Erichsonius_rosellus

Map 36

Material examined. New Brunswick, Charlotte Co., near Clark Ridge, $45.3155^{\circ} \mathrm{N}$, $67.4406^{\circ} \mathrm{W}, 27 . V .2007$, R. P. Webster, beaver pond, treading vegetation (1, RWC). Restigouche Co., Jacquet River Gorge P.N.A., $47.7357^{\circ} \mathrm{N}, 66.0774^{\circ} \mathrm{W}, 24 . V I .2008$, R. P. Webster, beaver pond margin, among leaves and sedges ( $1 \hat{\sigma}$, RWC). Sunbury Co., Maugerville, Portobello Creek N.W.A., $45.8992^{\circ}$ N, $66.4248^{\circ}$ W, 5.VI.2004, R. P. Webster, silver maple swamp, in leaf litter on margin of small pond ( 1 ऽ, RWC). York Co. $8.5 \mathrm{~km} \mathrm{~W}$ of Tracy, off Rt. 645, 45.6821 ${ }^{\circ} \mathrm{N}, 66.7894^{\circ} \mathrm{W}, 6 . V .2008$, R. P. Webster, wet alder swamp in leaf litter and grass on hummock (1 $\delta^{\lambda}$, RWC); Fredericton, University of New Brunswick Woodlot, $45.9116^{\circ} \mathrm{N}, 66.6698^{\circ} \mathrm{W}, 26 . V .2008$, R. Webster, G. Forbes, \& M.-A. Giguère, abandoned beaver lodge occupied by muskrats, in roof of lodge ( $3 \hat{\partial}, 1$ sex undetermined, RWC); University of New Brunswick Woodlot, $45.9391^{\circ} \mathrm{N}, 66.6747^{\circ} \mathrm{W}, 17 . \mathrm{VIII} .2009$, R. Webster, D. McAlpine, \& G. Forbes, in beaver lodge, within wall of lodge (1 $\partial^{\lambda}$, RWC).

Collection and habitat data. Almost nothing was previously known about the habitat associations of this species. The only record with habitat data reported in Frank (1975) included a specimen collected from a "pool seep". In New Brunswick, adults were found in leaf litter in wet habitats, such as beaver pond margins, a pond margin in a silver maple swamp, and a wet alder swamp. This species was also found in the walls of both a beaver lodge and an abandoned beaver lodge occupied by muskrats. Adults were collected in May, June, and August.

Distribution in Canada and Alaska. ON, QC, NB (Frank 1975).

\section{Gabrius appendiculatus Sharp, 1910}

http://species-id.net/wiki/Gabrius_appendiculatus

Map 37

Material examined. Additional New Brunswick records, Carleton Co., Meduxnekeag River Valley Nature Preserve, $46.1931^{\circ} \mathrm{N}, 67.6825^{\circ} \mathrm{W}, 15 . I X .2004$, R. P. Webster, river margin, under drift material (1 sex undetermined, RWC); Two Mile Brook Fen, $46.3619^{\circ} \mathrm{N}, 67.6733^{\circ} \mathrm{W}, 6$. V.2005, M.-A. Giguère \& R. Webster, eastern white cedar swamp, in moist sphagnum (1, NBM). Queens Co., Grand Lake near Scotchtown, $45.8762^{\circ} \mathrm{N}, 66.1816^{\circ} \mathrm{W}, 12 . \mathrm{V} .2004$, R. P. Webster, lake- 


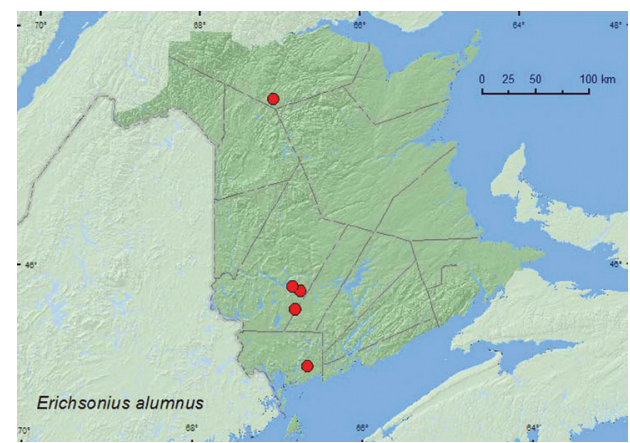

Map 3 I. Collection localities in New Brunswick, Canada of Erichsonius alumnus.

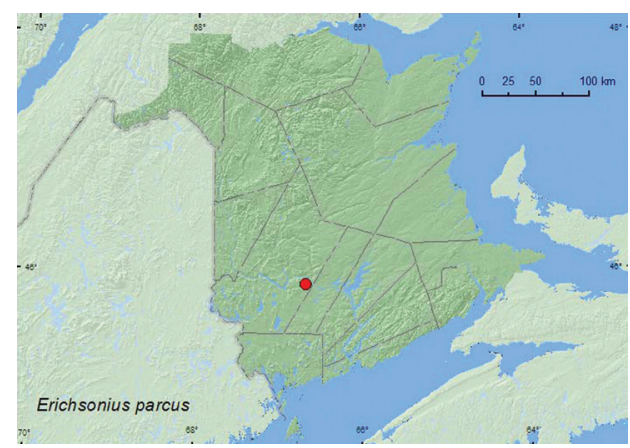

Map 33. Collection localities in New Brunswick, Canada of Erichsonius parcus.

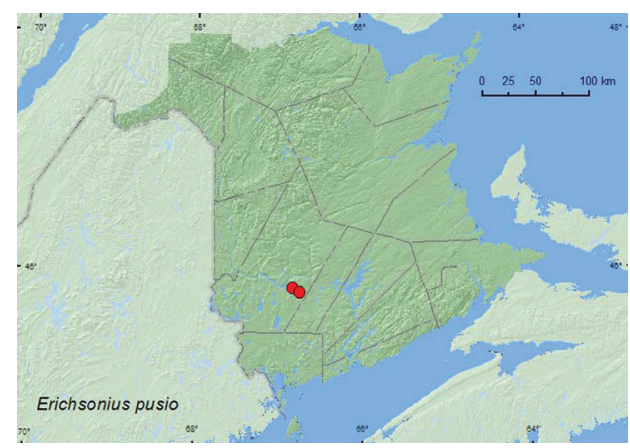

Map 35. Collection localities in New Brunswick, Canada of Erichsonius pusio.

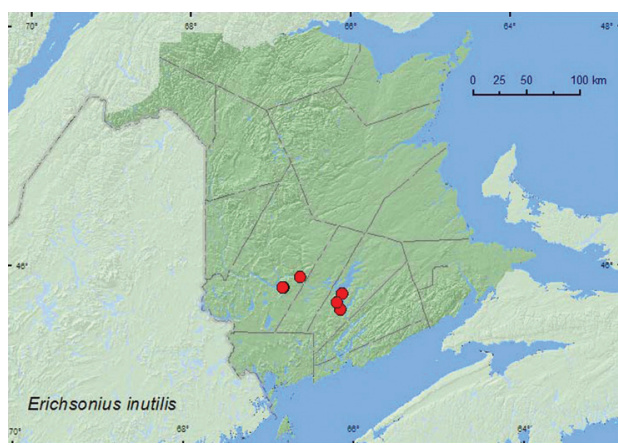

Map 32. Collection localities in New Brunswick, Canada of Erichsonius inutilis.

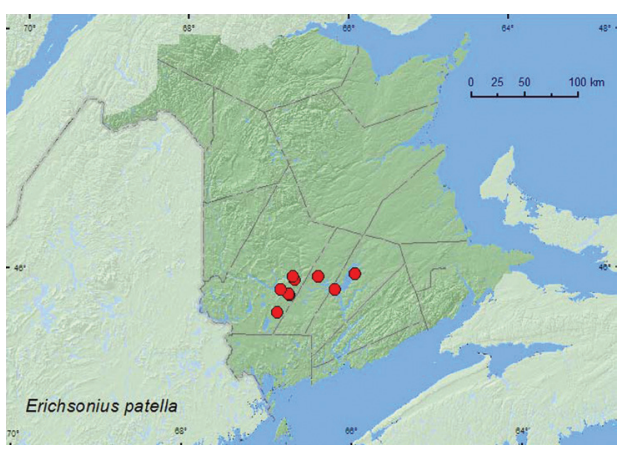

Map 34. Collection localities in New Brunswick, Canada of Erichsonius patella.

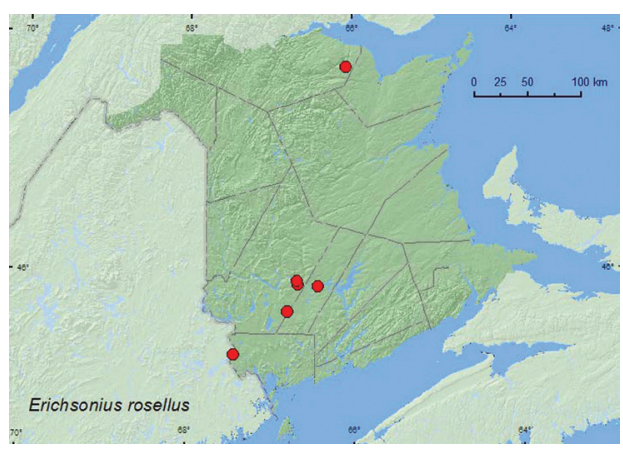

Map 36. Collection localities in New Brunswick, Canada of Erichsonius rosellus.

shore, under drift material ( 1 , RWC); Bayard (near Welsford) near Nerepis River, $45.4442^{\circ} \mathrm{N}, 66.3292^{\circ} \mathrm{W}, 25 . \mathrm{V} .2008$, R. P. Webster, pond margin, in moist grass litter on mud ( $1 \mathrm{O}^{\top}$, RWC). Sunbury Co., Acadia Research Forest, $45.9816^{\circ} \mathrm{N}$, $66.3374^{\circ} \mathrm{W}, 18$. VII.2007, R. P. Webster, regenerating mixed forest (8.5 years-old), in sphagnum and leaf litter at bottom of dried vernal pool (1, RWC). York Co., 
Charters Settlement, $45.8395^{\circ}$ N, 66.7391W, 22.IV.2004, 9.IV.2005, R. P. Webster, residential lawn in grass ( $1 \hat{\partial}, 1$ sex undetermined, RWC); same locality, forest type, and collector, 17.IV.2005, in flight, collected with aerial net during warm afternoon (1 sex undetermined, RWC); same locality and collector, 29.III.2006, mixed forest under alders near brook, in leaf litter ( 1 त, RWC); Fredericton, at Saint John River, $45.9588^{\circ} \mathrm{N}, 66.6254^{\circ} \mathrm{W}, 7 . V I .2005$, R. P. Webster, river margin, in flood debris ( $1 \mathrm{O}^{\mathrm{N}}$, RWC); Keswick River at Rt. $105,45.9938^{\circ} \mathrm{N}, 66.8344^{\circ} \mathrm{W}$, 3.VI.2008, R. P. Webster, silver maple swamp near river margin, in leaf and grass litter on mud/clay soil ( $\left.1 \mathrm{O}^{\top}, \mathrm{RWC}\right) ; 14 \mathrm{~km} \mathrm{WSW}$ of Tracy, $S$ of Rt. $645,45.6741^{\circ} \mathrm{N}$, $66.8661^{\circ} \mathrm{W}, 25 . \mathrm{IV}-4 . \mathrm{V} .2010$, R. Webster \& C. MacKay, old mixed forest with red and white spruce, red and white pine, balsam fir, eastern white cedar, red maple, and Populus sp., Lindgren funnel trap (1, AFC).

Collection and habitat data. In Europe, adults of this adventive species occur in wet habitats, marshes, swamps, margins of streams and ponds, and swampy meadows; it is found in similar habitats in North America (Smetana 1995). In New Brunswick, most adults were found along lake, pond, brook, and river margins, usually in leaf litter or drift material. Others were found in an eastern white cedar swamp in moist sphagnum, in a dried vernal pond in sphagnum and leaf litter. Klimaszewski et al. (2005) reported specimens from pitfall traps deployed in a red spruce stand (Acadia Research Forest). Adults were collected in March, April, May, June, July, and September.

Distribution in Canada and Alaska. BC, ON, QC, NB, NF (Smetana 1995; Klimaszewski et al. 2005; Brunke and Marshall 2011). Gabrius appendiculatus was first reported from New Brunswick by Klimaszewski et al. (2005).

\section{Gabrius fallaciosus (Horn 1884)**}

http://species-id.net/wiki/Gabrius_fallaciosus

Map 38

Material examined. New Brunswick, Carleton Co., Jackson Falls, Bell Forest, $46.2152^{\circ} \mathrm{N}, 67.7190^{\circ} \mathrm{W}, 1 . \mathrm{VI} .2005$, M.-A. Giguère \& R. Webster, upper river margin, in flight, collected with aerial net between 16:00 and 18:00 h (1, RWC); Hovey Hill P.N.A., $46.1115^{\circ} \mathrm{N}, 67.7770^{\circ} \mathrm{W}, 10$. V.2005, 24.V.2005, R. P. Webster, hardwood for-

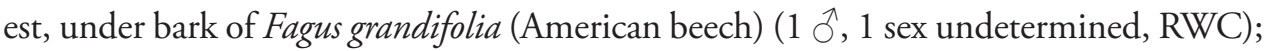
Meduxnekeag Valley Nature Preserve, $46.1883^{\circ} \mathrm{N}, 67.6745^{\circ} \mathrm{W}$, 9.VIII.2005, M.-A. Giguère \& R. Webster, old hardwood forest, under bark (1 $\hat{\delta}$, RWC). Charlotte Co., $3.0 \mathrm{~km}$ NW of Pomeroy Ridge, $45.3059^{\circ} \mathrm{N}, 67.4343^{\circ} \mathrm{W}, 5 . V I .2008$, R. P. Webster, red maple and eastern white cedar swamp, under bark of red maple (1 $0, \mathrm{NBM}) ; 10 \mathrm{~km}$ NW of New River Beach, $45.2110^{\circ} \mathrm{N}, 66.6170^{\circ} \mathrm{W}, 30 . I V-17 . V .2010$, R. Webster \& V. Webster, coll., old growth eastern white cedar forest, Lindgren funnel trap (1, AFC). Queens Co., ca. $3.5 \mathrm{~km} \mathrm{~W}$ of Lower Gagetown, $45.7497^{\circ} \mathrm{N}, 66.1846^{\circ} \mathrm{W}, 13 . \mathrm{V} .2008$, 
R. P. Webster, mature red oak and red maple forest, under bark (red oak) ( 1 ô, RWC); Central Hampstead, $45.6437^{\circ} \mathrm{N}, 66.1462^{\circ} \mathrm{W}, 13 . V .2008, \mathrm{R}$. P. Webster, mixed forest, under bark of hardwood (1, RWC); Cranberry Lake P.N.A., $46.1125^{\circ} \mathrm{N}, 65.6075^{\circ} \mathrm{W}$, 24.IV-5 V.2009, 21-27.V.2009, R. Webster \& M.-A. Giguère, mature red oak forest, Lindgren funnel traps (4, AFC). Sunbury Co., Noonan, $45.9923^{\circ} \mathrm{N}, 66.4099^{\circ} \mathrm{W}$, 2.VI.2007, S. Makepeace \& R. Webster, coll., nest contents of barred owl from tree hole $7 \mathrm{~m}$ high in red maple (1, RWC). York Co., Charters Settlement, $45.8395^{\circ} \mathrm{N}$, $66.7391^{\circ} \mathrm{W}, 1 . \mathrm{V} .2005$, R. P. Webster, mixed forest, under bark of conifer log (2, RWC); same locality and collector but $45.8286^{\circ} \mathrm{N}, 66.7365^{\circ} \mathrm{W}, 2 . \mathrm{VI} .2007$, old red spruce and red maple forest, under scolytid-infested bark of red spruce (1 $\hat{\sigma}$, RWC); $14 \mathrm{~km}$ WSW of Tracy, S of Rt. $645,45.6741^{\circ} \mathrm{N}, 66.8661^{\circ} \mathrm{W}, 26 . \mathrm{IV}-10 . V .2010$, R. Webster \& C. MacKay, coll., old mixed forest with red and white spruce, red and white pine, balsam fir, eastern white cedar, red maple, and Populus sp., Lindgren funnel trap (1, AFC).

Collection and habitat data. Smetana (1995) reported that this species typically occured under bark of both deciduous and coniferous species and was often associated with old trees. Adults occur in debris under bark, in rotting wood, and in wood and debris around the bases of dead standing trees. This species has also been found in rotting mushrooms and forest floor litter and has been taken in flight intercept traps (Smetana 1995). In New Brunswick, this species was found in similar habitats, including under bark of American beech, red maple, red oak, red spruce, and from the nest contents of a barred owl. Adults were also collected in Lindgren funnel traps and in flight during evening flights. Adults were captured during April, May, June, and August.

Distribution in Canada and Alaska. ON, QC, NB (Smetana 1995).

\section{Gabrius ulpius Smetana, 1995}

http://species-id.net/wiki/Gabrius_ulpius

Map 39

Material examined. New Brunswick, Restigouche Co., Little Tobique River near Red Brook, $47.4462^{\circ} \mathrm{N}, 67.0689^{\circ} \mathrm{W}, 24$. V.2007, R. P. Webster, old growth eastern white cedar forest, in moss and leaf litter near brook ( $1 \hat{\jmath}$, RWC).

Collection and habitat data. This species has been collected most frequently from deciduous forest habitats and has been collected from forest floor debris (moist deep leaf litter layers), in moss on rocks, in old mushrooms, and in rotten wood (Smetana 1995). The single New Brunswick specimen was sifted from moss and leaf litter adjacent to a brook in an old-growth eastern white cedar forest.

Distribution in Canada and Alaska. ON, QC, NB, NS (Smetana 1995). It is apparent from the above record that G. ulpius is probably more continuously distributed in the Maritime provinces than was suggested by Majka et al. (2009). 
Hesperus apicialis (Say, 1830)**

http://species-id.net/wiki/Hesperus_apicialis

Map 40

Material examined. New Brunswick, Queens Co., Cranberry Lake P.N.A., $46.1125^{\circ} \mathrm{N}, 65.6075^{\circ} \mathrm{W}$, R. Webster \& M.-A. Giguère, 24.IV.-5.V.2009, red oak forest, Lindgren funnel trap $(1 \hat{\delta}$, RWC); same locality data and forest type, 29.VI-7. VII.2011, 7-13.VII.2011, M. Roy \& V. Webster, Lindgren funnel traps in forest canopy (2, NBM, RWC). Sunbury Co., Noonan, $45.9923^{\circ}$ N, 66.4099 W, 2.VI.2007, S. Makepeace \& R. Webster, coll., nest contents (damp organic material with small bones) of barred owl from tree hole $7 \mathrm{~m}$ high in red maple, (1 9 , RWC); Acadia Research Forest, $45.9866^{\circ} \mathrm{N}, 66.3841^{\circ} \mathrm{W}, 9-16 . V I .2009$, R. Webster \& M.-A. Giguère, red spruce forest (100 years old) with red maple and balsam fir, Lindgren funnel trap (1 9 , RWC).

Collection and habitat data. Hesperus apicialis is associated with old trees, occurring under bark and in wood and debris of old, fallen, deciduous and coniferous trees and in tree holes (Smetana 1995). In New Brunswick, one adult was collected from the nest contents of a barred owl nesting in a tree hole. Other adults were collected from Lindgren funnel traps in red oak and red spruce forests. Two adults were captured in Lindgren funnel traps deployed in the forest canopy. Adults were collected in April, May, June, and July.

Distribution in Canada and Alaska. ON, QC, NB (Smetana 1995).

\section{Laetulonthus laetulus (Say, 1834)**}

http://species-id.net/wiki/Laetulonthus_laetulus

Map 41

Material examined. New Brunswick, Carleton Co., Jackson Falls, Bell Forest, $46.2200^{\circ} \mathrm{N}, 67.7231^{\circ} \mathrm{W}, 12-19 . V I .2008$, R. P. Webster, mature hardwood forest, Lindgren funnel trap (1 $\delta$, RWC); same locality data and collector, 12.IX.2008, in fleshy polypore mushroom on beech $\log (1, \mathrm{RWC})$. Charlotte Co., $10 \mathrm{~km} \mathrm{NW}$ of New River Beach, $45.2110^{\circ} \mathrm{N}, 66.6170^{\circ} \mathrm{W}, 31 . \mathrm{V}-15 . V I .2010$, R. P. Webster and V. Webster, coll., old-growth eastern white cedar forest, Lindgren funnel trap (1, AFC). Queens Co., Cranberry Lake P.N.A., $46.1125^{\circ} \mathrm{N}, 65.6075^{\circ} \mathrm{W}, 4-18 . V I I I .2011, \mathrm{M}$. Roy \& V. Webster, old red oak forest, Lindgren funnel trap (1, NBM). York Co., Charters Settlement, $45.8340^{\circ} \mathrm{N}, 66.7450^{\circ} \mathrm{W}, 14 . V .2004,30 . V .2004$, R. P. Webster, mixed forest, in wood pile, under bark of spruce log (1 ${ }^{\lambda}, 1$ \% , NBM, RWC); same locality and collector, $45.8395^{\circ} \mathrm{N}, 66.7391^{\circ} \mathrm{W}, 16 . X .2004,28$.IX.2005, 22.VIII.2005, 8.VIII.2008, mixed forest, in plastic compost bin with decaying vegetables (3 $\mathrm{O}, 3$ 9, RWC); $15 \mathrm{~km} \mathrm{~W}$ of Tracy off Rt. $645,45.6848^{\circ} \mathrm{N}, 66.8821^{\circ} \mathrm{W}, 15-21 . V I .2009$, 29.VII-4 VIII.2009, 4-11.VIII.2009, R. Webster \& M.-A. Giguère, Lindgren fun- 
nel traps (6, AFC); $14 \mathrm{~km} \mathrm{WSW} \mathrm{of} \mathrm{Tracy,} \mathrm{S} \mathrm{of} \mathrm{Rt.} 645,45.6741^{\circ} \mathrm{N}, 66.8661^{\circ} \mathrm{W}$, 10-26.V.2010, 26.V-2.VI.2010, R. Webster \& C. MacKay, coll., old mixed forest with red and white spruce, red and white pine, balsam fir, eastern white cedar, red maple, and Populus sp., Lindgren funnel traps (2, AFC).

Collection and habitat data. This species is associated with deciduous and coniferous trees, usually occurring in debris around bases of trees, in tree holes, under bark, and in rotting wood of old fallen trees (Smetana 1995). In New Brunswick, specimens were collected from compost (decaying vegetables) in a compost bin, from under bark of a spruce log, in a fleshy polypore mushroom on a beech log, and from Lindgren funnel traps. Adults were collected in May, June, July, August, and September.

Distribution in Canada and Alaska. ON, QC, NB (Smetana 1995).

\section{Neobisnius jucundus (Horn, 1884)**}

http://species-id.net/wiki/Neobisnius_jucundus

Map 42

Material examined. New Brunswick, Queens Co., Grand Lake, on Goat Island, $46.0110^{\circ} \mathrm{N}, 66.0133^{\circ} \mathrm{W}, 17$. VIII.2004, D. Sabine \& R. Webster, lake margin among

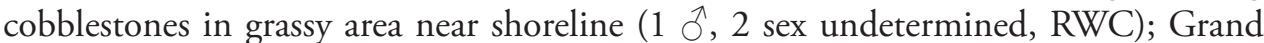
Lake at Cox Point, $46.0161^{\circ} \mathrm{N}, 65.9942^{\circ} \mathrm{W}, 17$. VIII.2004, D. Sabine \& R. Webster, lake margin among cobblestones near shoreline (3, RWC).

Collection and habitat data. Little is known about the habitat associations of this species. The few records with habitat data reported in Frank (1981) included salt marsh margins, a sand bar, and under drift on a (sea) beach. Some other collection localities were near lakes and river systems. All the New Brunswick specimens were found under cobblestones near the margin of a lake during August.

Distribution in Canada and Alaska. BC, AB, ON, NB (Frank 1981).

\section{Neobisnius lathrobioides (Baudi, 1848)**}

http://species-id.net/wiki/Neobisnius_lathrobioides

Map 43

Material examined. New Brunswick, Restigouche Co., Jacquet River Gorge P.N.A., $47.8257^{\circ} \mathrm{N}, 66.0779^{\circ} \mathrm{W}, 24$. V.2010, R. P. Webster, partially shaded cobblestone and sand bar near outflow of brook at the Jacquet River, under cobblestone on sand ( $1 \hat{\mathrm{O}}$, RWC).

Collection and habitat data. No bionomic information was reported in Frank (1981) for this adventive species. The single New Brunswick specimen was under a small rock on a cobblestone bar near a brook and river. The adult was collected in May.

Distribution in Canada and Alaska. QC, NB (Frank 1981). 


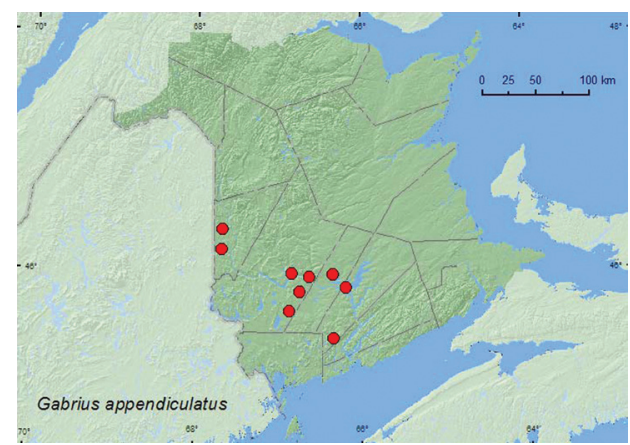

Map 37. Collection localities in New Brunswick, Canada of Gabrius appendiculatus.

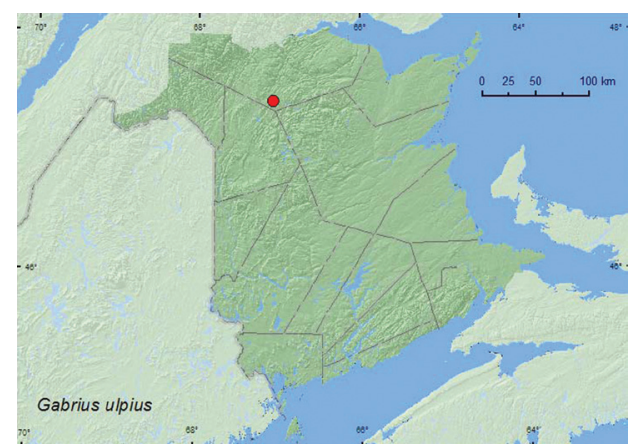

Map 39. Collection localities in New Brunswick, Canada of Gabrius ulpius.

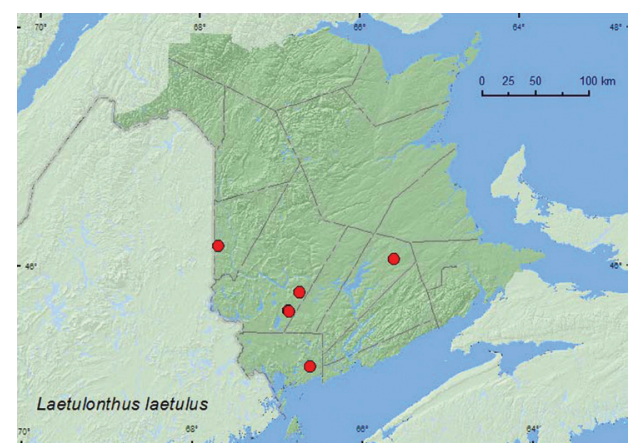

Map 4I. Collection localities in New Brunswick, Canada of Laetulonthus laetulus.

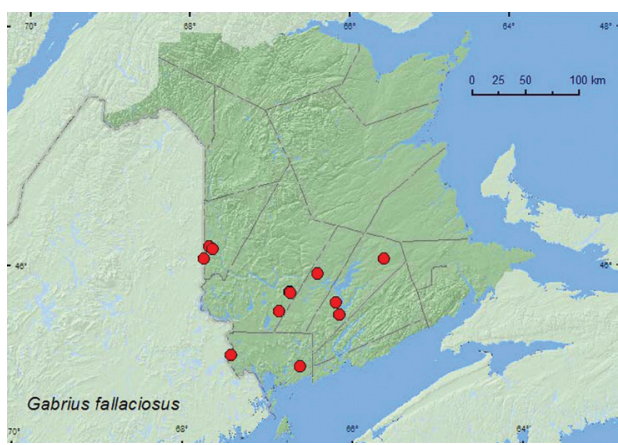

Map 38. Collection localities in New Brunswick, Canada of Gabrius fallaciosus.

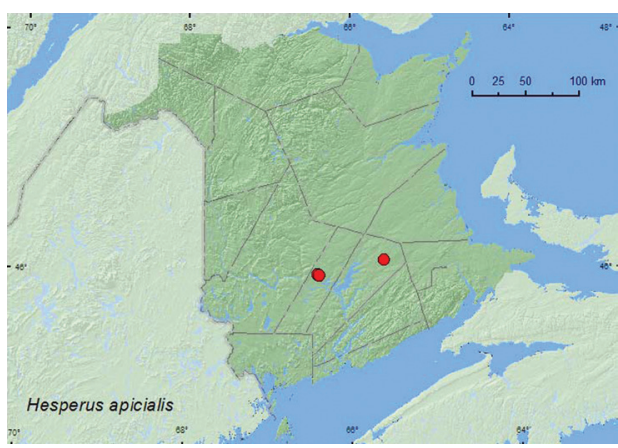

Map 40. Collection localities in New Brunswick, Canada of Hesperus apicialis.

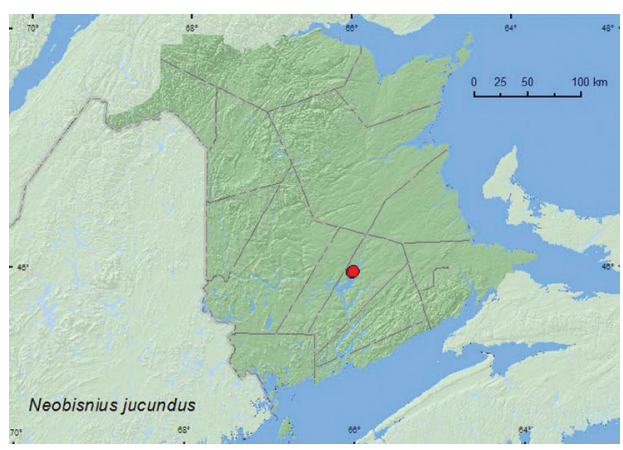

Map 42. Collection localities in New Brunswick, Canada of Neobisnius jucundus. 
Neobisnius terminalis (LeConte, 1863)

http://species-id.net/wiki/Neobisnius_terminalis

Map 44

Material examined. Additional New Brunswick records, Carleton Co., Hartland, (old) Hwy 2 at Saint John River, $46.3136^{\circ} \mathrm{N}, 67.5376^{\circ} \mathrm{W}, 2 . V I I I .2004$, R. P. Webster, river margin, on moist clay among tall grasses (1 sex undetermined, RWC); Hartland, Becaguimec Island (in Saint John River), $46.3073^{\circ} \mathrm{N}, 67.5376^{\circ} \mathrm{W}, 23 . V I .2006$, R. Capozi \& R. Webster, river margin among cobblestones near water $(1 \hat{\delta}, 2$ sex undetermined, RWC); Hartland, Middle Becaguimec Island (in Saint John River), $46.3028^{\circ} \mathrm{N}, 67.5333^{\circ} \mathrm{W}, 23$. VI.2006, R. Capozi \& R. Webster, river margin among cobblestones near water (1 $\delta$, 2 sex undetermined, RWC); Meduxnekeag River Valley Nature Preserve, $46.1942^{\circ} \mathrm{N}, 67.6832^{\circ} \mathrm{W}, 9 . V I .2008$, R. P. Webster, river margin, under small cobblestone set in sand and fine gravel near water (1, RWC). Madawaska Co., at Green River, $47.6918^{\circ}$ N, 68.3202 W, 21.VI.2010, M. Turgeon \& R. Webster, river margin, among gravel on gravel bar (1, NBM). Northumberland Co., Amostown, at Miramichi River, $46.5339^{\circ} \mathrm{N}, 66.2094^{\circ} \mathrm{W}, 11$.VIII.2006, R. P. Webster, river margin, among cobblestones near water (1, RWC). York Co., $1.5 \mathrm{~km} \mathrm{~N}$ of Durham Bridge at Nashwaak River, $46.1408^{\circ} \mathrm{N}, 66.6179^{\circ} \mathrm{W}, 15 . \mathrm{VI} .2008$, R. P. Webster, river margin, among cobblestones near outflow of brook ( $1 \hat{\sigma}$, RWC).

Collection and habitat data. Little is known about the habitat associations of this species. Most of the specimens collected in New Brunswick were found under cobblestones along river margins, usually close to water. Adults were collected in June and August.

Distribution in Canada and Alaska. QC, NB, NS (Frank 1981). Neobisnius terminalis was listed as occurring in New Brunswick by Majka et al. (2011) without any supporting references or data. Here, we provide the first documented records from New Brunswick.

\section{Philonthus aequalis Horn, 1884**}

http://species-id.net/wiki/Philonthus_aequalis

Map 45

Material examined. New Brunswick, Carleton Co., Meduxnekeag Valley Nature Preserve, $46.1976^{\circ} \mathrm{N}, 67.6850^{\circ} \mathrm{W}, 4 . V .2006$, R. P. Webster, mixed forest, margin of vernal pond in leaf litter ( $1 \partial^{\lambda}$, RWC); same locality but $46.1942^{\circ} \mathrm{N}, 67.6832^{\circ} \mathrm{W}, 9 . \mathrm{VI} .2008$, R. P. Webster, river margin, under cobblestone set in sand and fine gravel near water's edge (1 $\partial^{\top}$, RWC); Jackson Falls, Bell Forest, $46.2150^{\circ} \mathrm{N}, 67.7201^{\circ} \mathrm{W}, 14$. V.2006, R. P. Webster, river margin, in drift material near seepage area ( $1 \hat{\delta}, 1$, RWC). York Co., Fredericton, at Saint John River, $45.9588^{\circ} \mathrm{N}, 66.6254^{\circ} \mathrm{W}$, 4.VIII.2004, R. P. Webster, river margin, in drift material (mostly silver maple seeds) ( $3 \hat{\partial}$, RWC). 
Collection and habitat data. Philonthus aequalis occurs in wet habitats along margins of rivers and creeks, in swamps, marshes, and lake margins. Adults occur in flood debris and can also be collected by treading and sifting leaf litter in swampy forests (Smetana 1995). Most adults from New Brunswick were found along river margins in drift material. One individual was collected from leaf litter on the margin of a vernal pond in a mixed forest. Adults were collected in May, June, and August.

Distribution in Canada and Alaska. MB, ON, QC, NB (Smetana 1995).

\section{Philonthus boreas Smetana, 1995**}

http://species-id.net/wiki/Philonthus_boreas

Map 46

Material examined. New Brunswick, Queens Co., Grand Lake near Scotchtown, $45.8762^{\circ} \mathrm{N}, 66.1816^{\circ} \mathrm{W}, \mathrm{R}$. P. Webster, 12.V.2004, 25.V.2006, lakeshore, under drift material ( $1 \hat{\mathrm{O}}, 1$ 1 , RWC).

Collection and habitat data. Philonthus boreas has been collected from various wet habitats, including the muddy banks of a river among scattered low grassy vegetation, and by treading moss and grassy vegetation along lake and pond margins (Smetana 1995). In New Brunswick, adults of this northern transcontinental species were collected in drift material along a lakeshore in May.

Distribution in Canada and Alaska. AK, YT, NT, BC, AB, SK, MB, ON, NB, NF (Smetana 1995).

\section{Philonthus flavibasis Casey, 1915**}

http://species-id.net/wiki/Philonthus_flavibasis

Map 47

Material examined. New Brunswick, Carleton Co., "Two Mile Brook Fen", $46.3619^{\circ} \mathrm{N}, 67.6733^{\circ} \mathrm{W}, 6 . V .2005$, M.-A. Giguère \& R. Webster, eastern white cedar forest/swamp, in moist sphagnum (1 $\delta^{\lambda}, 2$ + , NBM, RWC). Charlotte Co., Rt. 3 at Deadwater Brook, $45.4744^{\circ} \mathrm{N}, 67.1225^{\circ} \mathrm{W}, 3 . V I .2005$, R. P. Webster, forested black spruce bog, in moist sphagnum (1 $\sigma^{7}$, RWC); $S$ of Little Pocologan River, $45.1537^{\circ} \mathrm{N}, 66.6269^{\circ} \mathrm{W}, 7 . V .2007, \mathrm{R}$. P. Webster, black spruce and tamarack bog, in moss and litter ( 2 + $, \mathrm{NBM}, \mathrm{RWC}) ; 3.5 \mathrm{~km} \mathrm{NW}$ of Pomeroy Ridge, $45.3087^{\circ} \mathrm{N}$, 67.4362 W, 5.V.2008, 18.VI.2008, R. P. Webster, red maple swamp, in sphagnum with grasses near margin of vernal pool $(6 \hat{0}, 1$, NBM, RWC). Northumberland Co., Goodfellow Brook P.N.A., $46.8943^{\circ} \mathrm{N}, 65.3796^{\circ} \mathrm{W}, 23 . V .2007$, R. P. Webster, old-growth eastern white cedar swamp, in grass litter and moss on hummocks near pool (1 $\hat{\jmath}$, NBM). Restigouche Co., NE of jct. Little Tobique River and Red Brook, $47.4501^{\circ} \mathrm{N}, 67.0577^{\circ} \mathrm{W}, 24 . \mathrm{V} .2007$, R. P. Webster, old growth eastern white cedar swamp, in moist sphagnum (2 $\hat{0}, 1$ +, $\mathrm{NBM}$, RWC); Jacquet River Gorge 
P.N.A., $47.8199^{\circ} \mathrm{N}, 66.0010^{\circ} \mathrm{W}, 25 . V I .2008$, R. P. Webster, mixed forest, margin vernal pool among moist leaves $(1 \hat{O}, \mathrm{NBM})$. Sunbury Co., Acadia Research Forest, $46.0173^{\circ} \mathrm{N}, 66.3741^{\circ} \mathrm{W}, 18 . \mathrm{IX} .2007, \mathrm{R}$. P. Webster, 8.5 year-old regenerating mixed forest, in sphagnum and leaf litter in old tire depression ( $4 \lambda, 1$,, $\mathrm{NBM}$, RWC). York Co., trail to Browns Mtn. Fen, $45.8978^{\circ}$ N, $67.6273^{\circ} \mathrm{W}, 2 . V .2005$, M.A. Giguère \& R. Webster, mature eastern white cedar forest near stream, in leaf litter (2 O$\left.^{\circ}, \mathrm{NBM}, \mathrm{RWC}\right)$; Browns Mtn. Fen, $45.8967^{\circ} \mathrm{N}, 67.6343^{\circ} \mathrm{W}, 2 . \mathrm{V} .2005$, M.-A. Giguère \& R. Webster, eastern white cedar fen, in moist sphagnum in area with sedges $\left(2{ }^{\lambda}, 2\right.$ ㅇ, NBM); New Maryland, off Hwy 2, E of Baker Brook, $45.8760^{\circ} \mathrm{N}$, $66.6252^{\circ} \mathrm{W}, 28 . I V .2005$, 4.VI.2005, R. P. Webster, old-growth eastern white cedar swamp, in moss and litter at base of cedar (2 $\mathrm{O}, \mathrm{NBM}) ; 9 \mathrm{~km} \mathrm{~W}$ of Tracy, off Rt.645, $45.6888^{\circ} \mathrm{N}, 66.8004^{\circ} \mathrm{W}, 22 . V .2008$, R. P. Webster, Carex marsh in hummock (1 +, NBM).

Collection and habitat data. This species was mostly found in sphagnum bogs and swamps, and adults were collected by sifting sphagnum and other mosses, leaf litter, grasses, cedar duff or treading vegetation into water (Smetana 1995). In New Brunswick, most adults were found in eastern white cedar swamps or tamarack bogs and were collected either by treading or sifting moist sphagnum. Adults were collected in April, May, June, and September.

Distribution in Canada and Alaska. AB, MB, ON, QC, NB (Smetana 1995).

\section{Philonthus janus Smetana, 1995**}

http://species-id.net/wiki/Philonthus_janus

Map 48

Material examined. New Brunswick, York Co., Charters Settlement, $45.8267^{\circ} \mathrm{N}$, 66.7343 ${ }^{\circ}$ W, 14.V.2005, 21.V.2006, R. P. Webster, Carex marsh / fen, treading Carex hummocks ( 1 ก, 1 \% , RWC).

Collection and habitat data. This species occurs in wet habitats such as marshes and can be collected by treading vegetation into water. This species has also been collected in numbers from beaver lodges and muskrat nests (Smetana 1995). The two New Brunswick specimens were collected during May by treading Carex hummocks in a Carex marsh.

Distribution in Canada and Alaska. SK, MB, ON, QC, NB (Smetana 1995).

\section{Philonthus monaeses Smetana, 1995}

http://species-id.net/wiki/Philonthus_monaeses

Map 49

Material examined. New Brunswick, Carleton Co., Jackson Falls, Bell Forest, $46.2150^{\circ} \mathrm{N}, 67.7201^{\circ} \mathrm{W}, 14 . \mathrm{V} .2006$, R. P. Webster, river margin in drift material near 


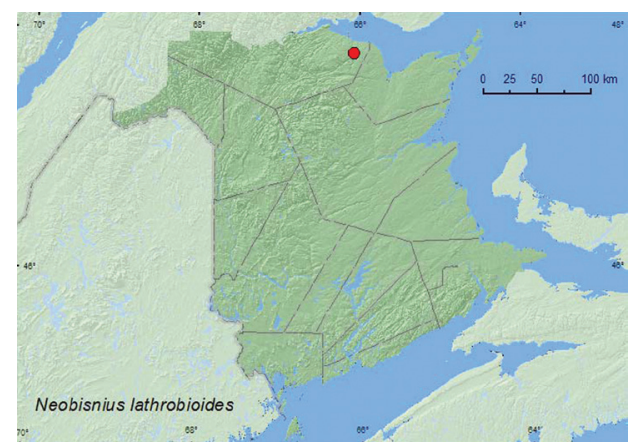

Map 43. Collection localities in New Brunswick, Canada of Neobisnius lathrobioides.

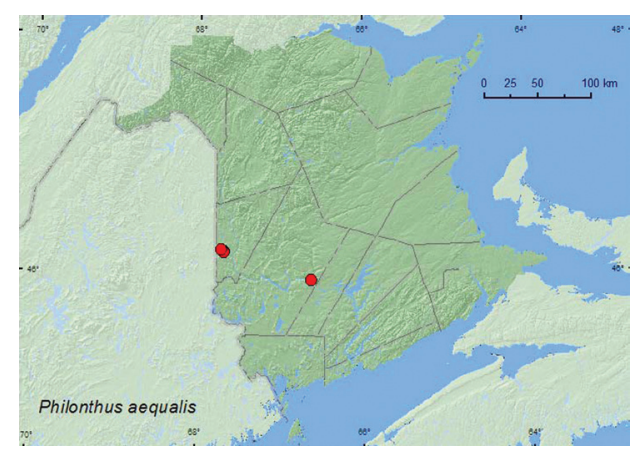

Map 45. Collection localities in New Brunswick, Canada of Philonthus aequalis.

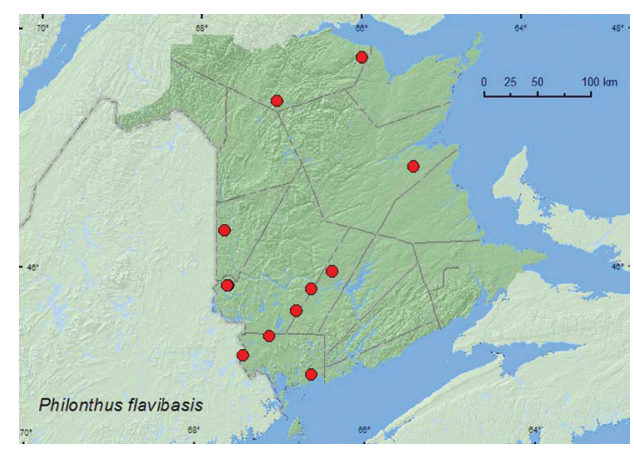

Map 47. Collection localities in New Brunswick, Canada of Philonthus flavibasis.

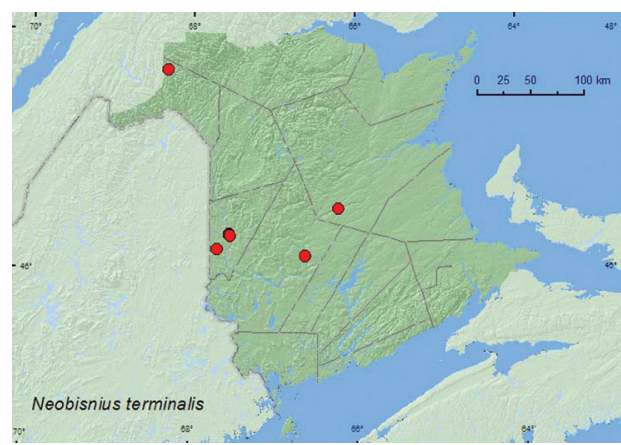

Map 44. Collection localities in New Brunswick, Canada of Neobisnius terminalis.

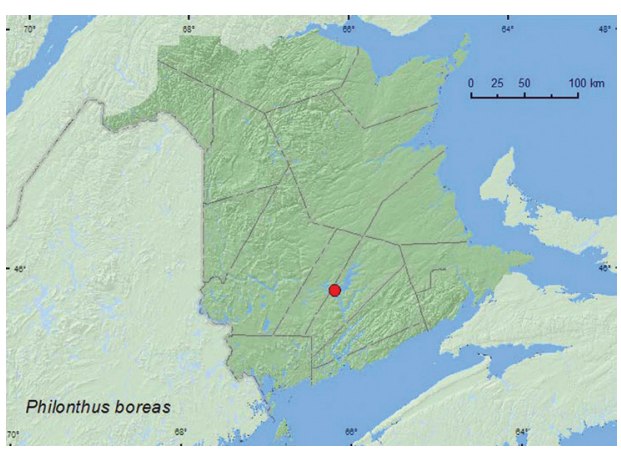

Map 46. Collection localities in New Brunswick, Canada of Philonthus boreas.

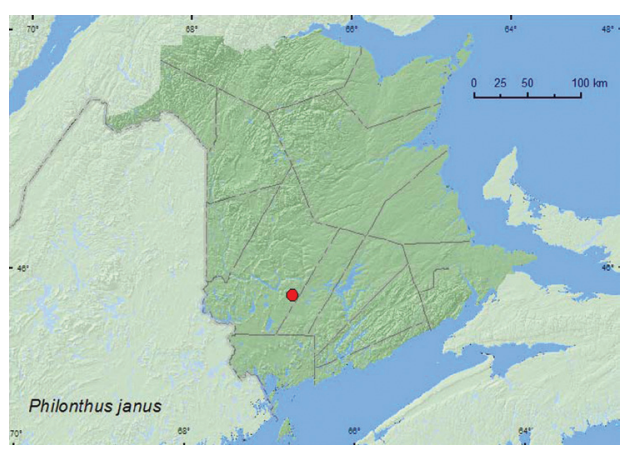

Map 48. Collection localities in New Brunswick, Canada of Philonthus janus.

seepage area ( 1 $\left.{ }^{\curvearrowright}, \mathrm{RWC}\right)$. Charlotte Co., near Clark Ridge, $45.3155^{\circ} \mathrm{N}, 67.4406^{\circ} \mathrm{W}$, 27.V.2007, R. P. Webster, beaver pond, treading (floating) vegetation (1 9 , RWC); 5.2 $\mathrm{km}$ NW of Pomeroy Ridge, $45.3087^{\circ} \mathrm{N}, 67.4362^{\circ} \mathrm{W}, 5 . V I .2008$, R. P. Webster, red maple swamp, in leaf litter near vernal pool (1 $\hat{\delta}$, RWC). Queens Co., Grand Lake near Indian Point, $45.8762^{\circ} \mathrm{N}, 66.1816^{\circ} \mathrm{W}, 5 . V I .2004$, R. P. Webster, lake margin under drift 
material (3 9 , RWC). Sunbury Co., Maugerville, Portobello Creek N.W.A., $45.8992^{\circ}$ N, $66.4248^{\circ} \mathrm{W}, 27 . V .2004$, R. P. Webster, silver maple swamp, margin of vernal pond in moist leaf litter (1 q, RWC). York Co., Dumfries, Slagundy Dry Ponds, $45.8596^{\circ} \mathrm{N}$, $67.1849^{\circ} \mathrm{W}, 8 . \mathrm{VII} .2006, \mathrm{R}$. P. Webster, large vernal pond, in moist leaves near water (1 $\delta^{\top}$, RWC); $8.5 \mathrm{~km} \mathrm{~W}$ of Tracy off Rt. $645,45.6888^{\circ} \mathrm{N}, 66.8004^{\circ} \mathrm{W}, 22 . \mathrm{V} .2008$, R. P. Webster, Carex marsh/flowage, near slow flowing brook in Carex hummocks ( $1 \hat{\jmath}$, RWC).

Collection and habitat data. This species occurs in a wide variety of wetland habitats, usually associated with standing water such as wet meadows, marshes, swamps, forest seepages, and along pond and lake margins (Smetana 1995). Some individuals were collected from muskrat nests. Adults were collected by sifting leaf litter, grass, and moss or by treading vegetation into water. In New Brunswick, this species was found in similar kinds of habitats. Adults were found in drift material near a seepage area along a river margin, among moist leaves on vernal pond margins in red maple and silver maple swamps, in a Carex hummock in a Carex flowage/marsh, in floating vegetation on a beaver pond margin, and in drift material on a lake margin. Adults were collected during May, June, and July.

Distribution in Canada and Alaska. ON, QC, NB, (Smetana 1995).

\title{
Philonthus neonatus Smetana, 1965
}

http://species-id.net/wiki/Philonthus_neonatus

Map 50

Materal examined. New Brunswick, Carleton Co., Meduxnekeag Valley Nature Preserve, $46.1931^{\circ} \mathrm{N}, 67.6825^{\circ} \mathrm{W}, 13 . \mathrm{VII} .2004$, R. P. Webster, river margin, under drift material (1 q, RWC); Becaguimec Island, $46.3073^{\circ} \mathrm{N}, 67.5376^{\circ} \mathrm{W}, 23 . \mathrm{VI} .2006, \mathrm{R}$. Capozi \& R. Webster, river margin, on sand near water (1 $\left.\sigma^{\top}, \mathrm{RWC}\right)$. Queens Co., Bayard at Nerepis River, $45.4473^{\circ} \mathrm{N}, 66.3318^{\circ} \mathrm{W}, 24$. V.2009, R. P. Webster, river margin, on sand bar, in debris on sand (7 $\hat{0}, 1$, RWC).

Collection and habitat data. Philonthus neonatus is generally a riparian species occurring along the margins of creeks and smaller rivers and beaches of larger lakes, usually in flood debris (Smetana 1995). The New Brunswick specimens were collected from similar habitats during May and June. Adults were collected along river margins from under drift material, on sand and from debris resting on sand on a sand bar.

Distribution in Canada and Alaska. ON, QC, NB, NS (Smetana 1995).

\author{
Philonthus pseudolus Smetana, 1995** \\ http://species-id.net/wiki/Philonthus_pseudolus \\ Map 51
}

Material examined. New Brunswick, Carleton Co., Trail to "Two Mile Brook Fen", $46.3600^{\circ} \mathrm{N}, 67.6815^{\circ} \mathrm{W}, 10 . \mathrm{V} .2005$, R. P. Webster, cattail /Carex marsh, treading 
Carex hummocks into water (1 $\delta^{\top}$, RWC). Madawaska Co., Third Lake, $47.7786^{\circ} \mathrm{N}$, $68.3783^{\circ} \mathrm{W}, 21 . \mathrm{VI} .2010$, R. P. Webster, lake margin, in gravel among scattered sedges (1 $\jmath^{7}$, RWC). Queens Co., Grand Lake near Scotchtown, $45.8762^{\circ} \mathrm{N}, 66.1816^{\circ} \mathrm{W}$, 30.IV.2006, R. P. Webster, lake shore, in drift material (1 $\widehat{\jmath}$, RWC). York Co., 8.5 $\mathrm{km}$ W of Tracy off Rt. 645, $45.6888^{\circ} \mathrm{N}, 66.8004^{\circ} \mathrm{W}, 22 . V .2008$, R. P. Webster, Carex marsh / flowage near slow flowing brook, in Carex hummock (1 $\hat{\sigma}, \mathrm{RWC})$.

Collection and habitat data. This species occurs in moist to wet habitats such as marshes, swamps, marshy margins of lakes and ponds and in muskrat nests. Adults are collected by treading vegetation (Carex and Typha and other vegetation) into water (Smetana 1995). In New Brunswick, adults were collected by treading Carex hummocks in Carex marshes and sifting drift material along lake margins. Adults were collected during April, May, and June.

Distribution in Canada and Alaska. BC, AB, MB, ON, QC, NB (Smetana 1995).

\section{Philonthus sericinus Horn, 1884**}

http://species-id.net/wiki/Philonthus_sericinus

Map 52

Material examined. New Brunswick, Carleton Co., Meduxnekeag River Valley Nature Preserve, $46.1907^{\circ} \mathrm{N}, 67.6740^{\circ} \mathrm{W}, 14 . I X .2005$, R. P. Webster, mixed forest, in decaying mushrooms (1 ${ }^{\lambda}$, RWC). Sunbury Co., Acadia Research Forest, $46.0173^{\circ} \mathrm{N}$, $66.3741^{\circ} \mathrm{W}, 17-23$. VIII.2007, R. P. Webster, 8.5-year-old regenerating mixed forest, pitfall trap (1, AFC). York Co., Charters Settlement, $45.8395^{\circ} \mathrm{N}, 66.7391^{\circ} \mathrm{W}$, 17.VII.2004, 6.V.2008, R. P. Webster, mixed forest, in compost (decaying vegetables) (2 $\mathrm{\jmath}$, RWC); same locality and collector, $45.8430^{\circ} \mathrm{N}, 66.7275^{\circ} \mathrm{W}, 17 . \mathrm{IX} .2004$, 25.IX.2004, regenerating mixed forest, baited with pile of decaying mushrooms $(1 \hat{\sigma}$, 4 ㅇ, RWC); same locality data and collector, 5.VI.2004, under carrion (1 9 , RWC).

Collection and habitat data. This species occurs in various rotting organic materials such as compost, rotting grass clippings, decaying fruit, vegetables, and decaying mushrooms, and rarely in forest floor leaf litter (Smetana 1995). In New Brunswick, most adults were found in decaying mushrooms in mixed forests. Adults were collected in May, June, July, August, and September.

Distribution in Canada and Alaska. ON, QC, NB (Smetana 1995).

\section{Philonthus subvirescens Thomson, 1884**}

http://species-id.net/wiki/Philonthus_subvirescens

Map 53

Material examined. New Brunswick, Madawaska Co., at Green River, $47.6918^{\circ} \mathrm{N}$, $68.3202^{\circ} \mathrm{W}, 21 . \mathrm{VI} .2010$, R. P. Webster, river margin among gravel on gravel bar $(1)$, 
RWC). Restigouche Co., Kedgwick Forks, 47.9085 N, 67.9057 W, 22.VI.2010, R. P. Webster, river margin, in flood debris, on gravel bar among gravel and cobblestones (4 §̊, RWC).

Collection and habitat data. Philonthus subvirescens is a riparian species found on sandy and gravel margins in areas with sparse vegetation (Smetana 1995). This species was found among gravel and flood debris along the margins of small fast-flowing rivers in New Brunswick.

Distribution in Canada and Alaska. AK, YT, NT, BC, AB, QC, NB (Smetana 1995). Philonthus subvirescens is a Holarctic species with a mostly western distribution from Alaska and the Northwest Territories south to the mountains of California and east to New Mexico, with a significantly disjunct population in Quebec on the Gaspé Peninsula (Smetana 1995). The presence of this species in northwestern New Brunswick indicates that this species has a somewhat wider distribution in easternmost Canada.

\section{Philonthus thoracicus (Gravenhorst, 1802)}

http://species-id.net/wiki/Philonthus_thoracicus

Map 54

Material examined. Additional New Brunswick records. Carleton Co., Becaguimec Island, $46.3106^{\circ} \mathrm{N}, 67.5392^{\circ} \mathrm{W}, 16 . \mathrm{IX} .2006$, R. Capozi \& R. Webster, hardwood forest (on island in Saint John River), on Pleurotus sp. on log (1 $\left.\sigma^{\top}, \mathrm{RWC}\right)$. Queens Co., W of Jemseg at "Trout Creek", 45.8231 ${ }^{\circ} \mathrm{N}, 66.1245^{\circ} \mathrm{W}, 3 . I V .2006$, R. P. Webster, silver maple swamp, sifting litter from crotch silver maple with multiple trunks $(1+$, RWC). Sunbury Co., Lakeville Corner, $45.9008^{\circ} \mathrm{N}, 66.2414^{\circ} \mathrm{W}, 12$.VII.2006, R. P. Webster, silver maple swamp on ridge with red oak and red maple, in litter at base of tree (1 9 , RWC). York Co. Fredericton, Nashwaaksis River at Rt. $105,45.9850^{\circ} \mathrm{N}$, $66.6900^{\circ} \mathrm{W}, \mathrm{R}$. P. Webster, in flood debris on upper river margin (1 $\mathrm{O}, 1$ q, RWC).

Collection and habitat data. This species has been found in open, often dry habitats with sandy substrates (open pine forests) and in moist to wet habitats near water, such as sandy creek, river, and pond margins (Smetana 1995). Adults occurred in leaf litter and debris. Specimens were also found in entrances of Marmota burrows (Smetana 1995). In New Brunswick, this species was found in silver maple floodplain forests, a hardwood forest on an island in a large river, and on an upper river margin. Adults were collected from leaf litter from a crotch of a silver maple with multiple trunks, litter at the base of a tree, in flood debris, and from Pleurotus mushrooms on a log.

Distribution in Canada and Alaska. AB, SK, MB, ON, QC, NB (Smetana 1995). Philonthus thoracicus was previously known from New Brunswick from one specimen collected by G.A. Calderwood in the Kouchibouguac National Park (Smetana 1995). It is apparent from the above records that this species is more widely distributed in the Maritime provinces than was suggested by the distributional gaps shown in Majka et al. (2009). Floodplain forests should be sampled for this species in Nova Scotia. 


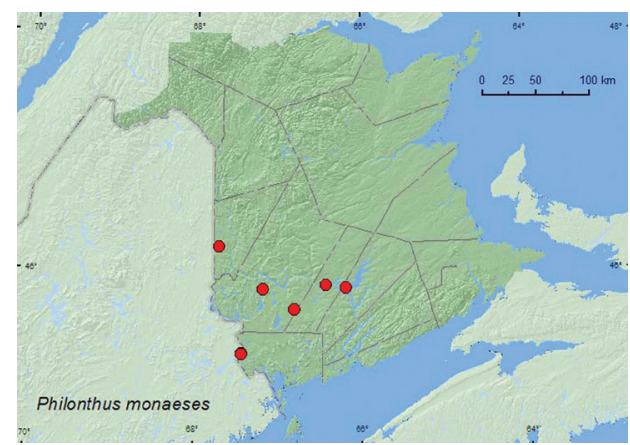

Map 49. Collection localities in New Brunswick, Canada of Philonthus monaeses

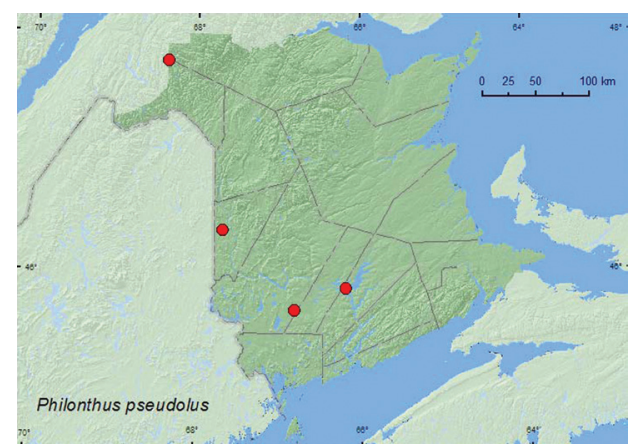

Map 5 I. Collection localities in New Brunswick, Canada of Philonthus pseudolus.

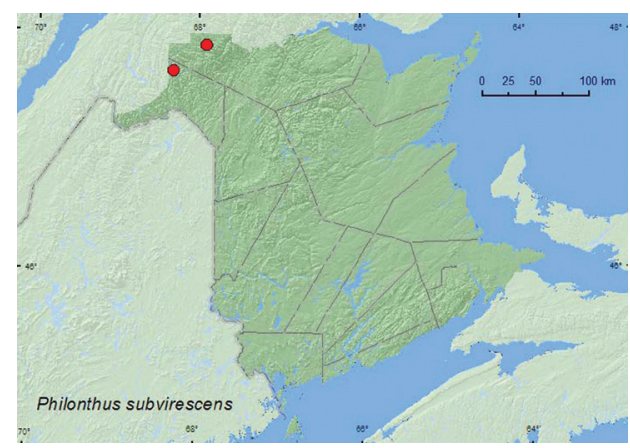

Map 53. Collection localities in New Brunswick, Canada of Philonthus subvirescens.

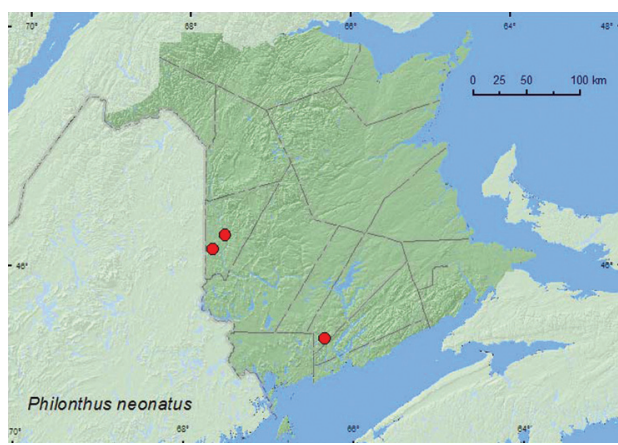

Map 50. Collection localities in New Brunswick, Canada of Philonthus neonatus.

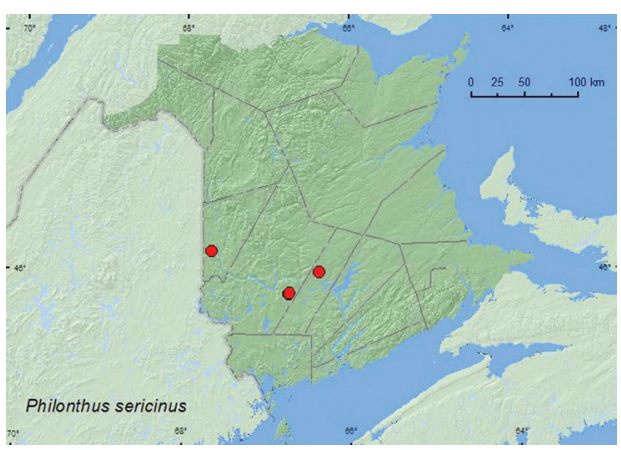

Map 52. Collection localities in New Brunswick, Canada of Philonthus sericinus.

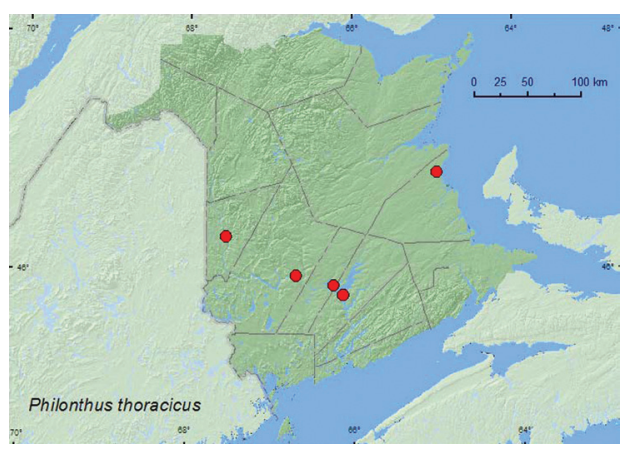

Map 54. Collection localities in New Brunswick, Canada of Philonthus thoracicus. 
Philonthus umbrinoides Smetana, 1995

http://species-id.net/wiki/Philonthus_umbrinoides

Map 55

Material examined. New Brunswick, Carleton Co., "Two Mile Brook Fen", $46.3594^{\circ} \mathrm{N}, 67.6800^{\circ} \mathrm{W}, 2 . V I .2005$, R. P. Webster, on (dirt) road through eastern white cedar swamp, in flight late afternoon ( 1 , RWC). Charlotte Co., near Clark Ridge, $45.3155^{\circ} \mathrm{N}, 67.4406^{\circ} \mathrm{W}, 26 . \mathrm{V} .2007$, R. P. Webster, beaver pond, treading vegetation (1 +, RWC). Queens Co., Grand Lake near Scotchtown, $45.8762^{\circ} \mathrm{N}, 66.1816^{\circ} \mathrm{W}$, 12.V.2004, R. P. Webster, lakeshore, under drift material (1 $\widehat{\jmath}$, RWC). Sunbury Co., Sheffield, Portobello Creek N.W.A., $45.8952^{\circ}$ N, $66.2728^{\circ}$ W, 7.V.2004, R. P. Webster, silver maple swamp, in leaf litter ( $1 \hat{\sigma}$, RWC).

Collection and habitat data. This species occurs in moist to wet habitats such as marshes, swamps, marshy margins of lakes and ponds, and in muskrat nests. Adults have been collected by treading vegetation (floating sphagnum mats, sedges and mosses, Typha plants, reeds) into water (Smetana 1995). In New Brunswick, adults were collected by treading vegetation along a beaver pond margin, from under drift material on a lake margin, sifting leaf litter in a silver maple swamp, and in flight during evening. Adults were collected in May and June.

Distribution in Canada and Alaska. AB, MB, ON, QC, NB, NS (Smetana 1995).

\section{Philonthus vulgatus Casey, 1915}

http://species-id.net/wiki/Philonthus_vulgatus

Map 56

Material examined. New Brunswick, Queens Co., Grand Lake near Scotchtown, $45.8762^{\circ} \mathrm{N}, 66.1816^{\circ} \mathrm{W}, 5 . V I .2004$, R. P. Webster, lakeshore, under drift material (1 +, RWC); same locality and collector, 9.VII.2006, oak maple forest near lakeshore, m.v. light ( 1 \%, 3 क , RWC); Grand Lake at Flowers Cove, $46.0196^{\circ} \mathrm{N}, 66.0246^{\circ} \mathrm{W}$, 26.VIII.2004, D. Sabine \& R. Webster, lake margin, under drift material (1 9 , RWC). Saint John Co., Musquash, $45.1856^{\circ} \mathrm{N}, 66.3402^{\circ} \mathrm{W}, 30$. V.2006, R. P. Webster, Carex and cattail marsh, treading ( 1 $\hat{O}$, RWC). Sunbury Co., Sheffield, Portobello Creek N.W.A., $45.8952^{\circ} \mathrm{N}, 66.2728^{\circ} \mathrm{W}$, R. P. Webster, 18.VI.2004, silver maple swamp, u.v. light trap (2 $\hat{\sigma}, \mathrm{RWC})$.

Collection and habitat data. Philonthus vulgatus occurs in debris along margins of ponds, lakes, swamps, marshes, creeks, and rivers, in beaver lodges and muskrat nests, and it commonly comes to light (Smetana 1995). In New Brunswick, adults were found under drift material along lake margins and at an ultraviolet light. Adults were collected during June, July, and August.

Distribution in Canada and Alaska. AK, BC, AB, SK, MB, ON, QC, NB, NS, PE, NF (Smetana 1995; Brunke and Marshall 2011). 


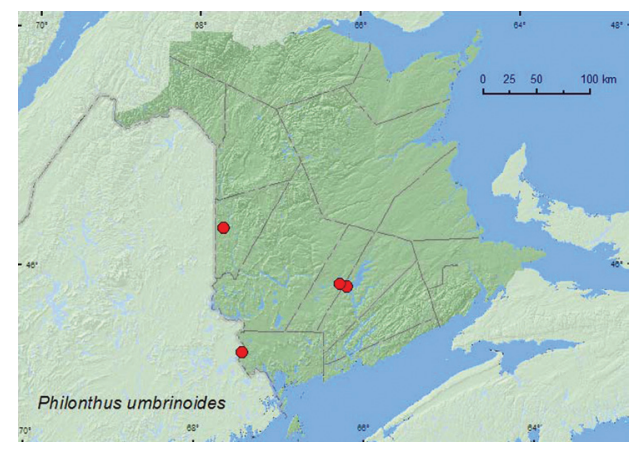

Map 55. Collection localities in New Brunswick, Canada of Philonthus umbrinoides.

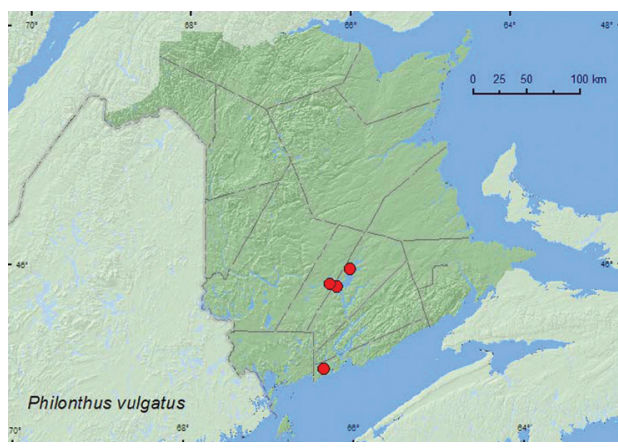

Map 56. Collection localities in New Brunswick, Canada of Philonthus vulgatus.

\section{Acknowledgments}

We thank Caroline Simpson for editing this manuscript and two anonymous reviewers for their helpful suggestions. Jan Klimaszewski (NRCan, CFS - Laurentian Forestry Centre, Ste-Foy, Quebec), Greg Pohl, and David Langor (NRCan, CFS -Northern Forestry Centre, Edmondton, Alberta) revised the first draft of this manuscript and provided very useful comments. We thank Peter Silk and Peter Mayo for synthesizing and providing attractants, Nichole Brawn, Katie Burgess, Robert Capozi, Jim Edsall, Marie-Andrée Giguère, Graham Forbes, Nancy Harn, Cory Hughes, Rob Johns, Ervin Kovacs, Marsell Laity, Colin MacKay, Wayne MacKay, Donald McAlpine, P. Poitras, Jessica Price, F. Roy, Michelle Roy, and Vincent Webster for technical assistance and collecting specimens. C. Chantal is thanked for supplying the record of Quedius criddlei from Quebec. We thank Natural Resources Canada - Canadian Forest Service; the Canadian Food Inspection Agency; and USDA APHIS for funding the study on early detection of invasive cerambycids, which provided many specimens in Lindgren funnel traps. The Canadian Wildlife Service is thanked for funding insect surveys at the Portobello Creek National Wildlife Area, the New Brunswick Environmental Trust Fund and New Brunswick Wildlife Trust Fund for funding various insect surveys over the past 6 years, and the Meduxnekeag River Association for permission to sample beetles at the Meduxnekeag Valley Nature Preserve (which includes the Bell Forest). The New Brunswick Department of Natural Resources (Fish and Wildlife Branch) is thanked for issuing permits for sampling in the Protected Natural Areas and providing logistical support. Survey work in the Jacquet River Gorge and Caledonia Gorge Protected Natural Areas was organized through the New Brunswick Museum with external funding from the New Brunswick Environmental Trust Fund, Salamander Foundation, and the New Brunswick Wildlife Trust Fund. 


\section{References}

Allison JD, Borden JH, Seybold SJ (2004) A review of the chemical ecology of the Cerambycidae (Coleoptera). Chemoecology 14: 123-150. doi: 10.1007/s00049-004-0277-1

Bishop DJ, Majka CG, Bondrup-Nielsen S, Peck SB (2009) Deadwood and saproxylic beetle diversity in naturally disturbed and managed spruce forests in Nova Scotia. In: Majka CG, Klimaszewski J (Eds) Biodiversity, biosystematics, and ecology of Canadian Coleoptera II. ZooKeys 22: 309-340. doi: 10.3897/zookeys.22.144

Blatchley WS (1910) An Illustrated Descriptive Catalogue of the Coleoptera or Beetles (exclusive of the Rhynchophora) Known to Occur in Indiana. The Nature Publishing Company, Indianapolis, USA, $1386 \mathrm{pp}$.

Bouchard P, Bousquet Y, Davies AE, Alonso-Zarazaga MA, Lawrence JF, Lyal CHC, Newton AF, Reid CAM, Schmitt M, Ślipiński SA, Smith ABT (2011) Family-group names in Coleoptera (Insecta). ZooKeys 88: 1-972. doi: 10.3897/zookeys.88.807

Brunke AJ, Marshall SA (2011) Contributions to the faunistics and bionomics of Staphylinidae (Coleoptera) in northeastern North America: discoveries made through study of the University of Guelph Insect Collection, Ontario, Canada. ZooKeys 75: 29-68. doi: 10.3897/ zookeys.75.767

Brunke A, Newton A, Klimaszewski J, Majka C, Marshall S (2011) Staphylinidae of eastern Canada and adjacent United States. Key to subfamilies: Staphylininae: tribes and subtribes, and species of Staphylinina. Canadian Journal of Arthropod Identification 12: 1-110.

Campbell JM (1973) A revision of the genus Tachinus (Coleoptera: Staphylinidae) of North and Central America. Memoirs of the Entomological Society of Canada 90: 1-137. doi: 10.4039 /entm $10590 \mathrm{fv}$

Campell JM, Davies A (1991) Family Staphylinidae: rove beetles. In: Bousquet Y (Ed) Checklist of Beetles of Canada and Alaska, Publication 1861/E, Agriculture Canada, Research Branch, Ottawa, Ontario, 86-124.

Frank JH (1975) A revision of the New World species of the genus Erichsonius Fauvel (Coleoptera: Staphylinidae). The Coleopterists Bulletin 29(3): 177-203.

Frank JH (1981) A revision of the New World species of the genus Neobisnius Ganglbauer (Coleoptera: Staphylinidae: Staphylininae). Occasional Papers of the Florida State Collection of Arthropods 1: i-vii, 1-60.

Hanks LM, Millar JG, Moreira JA, Barbour JD, Lacey ES, McElfresh JS, Reuter FR, Ray AM (2007) Using generic pheromone lures to expedite identification of aggregation pheromones for the cerambycid beetles Xylotrechus nauticus, Phymatodes lecontei, and Neoclytus modestus modestus. Journal of Chemical Ecology 33: 889-907. doi: 10.1007/s10886-007-9275-4

Klimaszewski J, Sweeney J, Price J, Pelletier G (2005) Rove beetles (Coleoptera: Staphylinidae) in red spruce stands, eastern Canada: diversity, abundance, and descriptions of new species. The Canadian Entomologist 137: 1-48. doi: 10.4039/n03-123

Lindgren BS (1983) A multiple funnel trap for scolytid beetles (Coleoptera). The Canadian Entomologist 115: 299-302. doi: 10.4039/Ent115299-3 
Majka CG, Brown L (2010) Quedius spelaeus Horn, a troglophlic beetle discovered in New Brunswick, Canada. Journal of the Acadian Entomological Society 6: 44-47.

Majka CG, Chandler DS, Donahue CP (2011) Checklist of the beetles of Maine, USA. Empty Mirrors Press, Halifax, Nova Scotia, 328 pp.

Majka CG, Klimaszewski J (2008a) Adventive Staphylinidae (Coleoptera) of the Maritime provinces of Canada: further contributions. ZooKeys 2: 151-174. doi: 10.3897/zookeys.2.5

Majka CG, Klimaszewski J (2008b) Introduced Staphylinidae (Coleoptera) in the Maritime provinces of Canada. The Canadian Entomologist 140: 48-72. doi: 10.4039/n06-099

Majka CG, Michaud J-P, Moreau G, Smetana A (2009) Philonthus hepaticus (Coleoptera, Staphylinidae) in eastern Canada: are distribution gaps distinctive features or collecting artifacts? In: Majka CG, Klimaszewski J (Eds) Biodiversity, biosystematics, and ecology of Canadian Coleoptera II. ZooKeys 22: 347-354. doi: 10.3897/zookeys.22.208

Majka CG, Smetana A (2007) New records of introduced species of Quedius Stephens, 1829 (Coleoptera: Staphylinidae) from the Maritime provinces of Canada. Proceedings of the Entomological Society of Washington 109(2): 427-434.

Pohl GR, Langor DW, Spence JR (2007) Rove beetles and ground beetles (Coleoptera: Staphylinidae, Carabidae) as indicators of harvest and regeneration practices in western Canadian foothills forests. Biological Conservation 137: 294-307. doi: 10.1016/j.biocon.2007.02.011

Smetana A (1965) Staphylinini und Quediini (Col., Staphylinidae) von Newfoundland, Sudost-Labrador und Nova Scotia. Acta Entomologica Fennica 20: 1-60.

Smetana A (1971a) Revision of the tribe Quediini of America north of Mexico (Coleoptera: Staphylinidae). Memoirs of the Entomological Society of Canada 79: 1-303. doi: 10.4039/ entm $10379 \mathrm{fv}$

Smetana A (1971b) Revision of the tribe Quediini of America north of Mexico (Coleoptera: Staphylinidae). Supplementum. The Canadian Entomologist 103: 1833-1848. doi: 10.4039/Ent1031833-12

Smetana A (1973) Revision of the tribe Quediini of America north of Mexico (Coleoptera: Staphylinidae). Supplementum 2. The Canadian Entomologist 105: 1421-1434. doi: 10.4039/Ent1051421-11

Smetana A (1976) Revision of the tribe Quediini of America north of Mexico (Coleoptera: Staphylinidae). Supplementum 3. The Canadian Entomologist 108: 169-184. doi: 10.4039/ Ent108169-2

Smetana A (1978) Revision of the tribe Quediini of America north of Mexico (Coleoptera: Staphylinidae). Supplementum 4. The Canadian Entomologist 110: 815-840. doi: 10.4039/ Ent110815-8

Smetana A (1981) Revision of the tribe Quediini of America north of Mexico (Coleoptera: Staphylinidae). Supplementum 5. The Canadian Entomologist 113: 631-644. doi: 10.4039/ Ent113631-7

Smetana A (1982) Revision of the subfamily Xantholininae of America north of Mexico (Coleoptera: Staphylinidae). Memoirs of the Entomological Society of Canada, 120: 1-389. doi: $10.4039 /$ entm $120142 \mathrm{fv}$ 
Smetana A (1988) Revision of the subfamily Xantholininae of America north of Mexico (Coleoptera: Staphylinidae). Supplementum 1. The Canadian Entomologist 120: 525-558. doi: 10.4039/Ent120525-6

Smetana A (1990) Revision of the tribe Quediini of America north of Mexico (Coleoptera: Staphylinidae). Supplementum 6. The Coleopterists Bulletin 44: 95-104.

Smetana A (1995) Rove beetles of the Philothina of America north of Mexico (Coleoptera: Staphylinidae). Classification, phylogeny and taxonomic revision. Memoirs on Entomology, International 3: i-x, 1-946.

Smetana A, Webster RP (2011) A new species of the genus Quedius Stephens, 1829, subgenus Microsaurus Dejean, 1833, from northeastern North America (Coleoptera, Staphylinidae, Staphylinini, Quediina). ZooKeys 126: 39-47. doi: 10.3897/zookeys.126.1647

Webster RP, Klimaszewski J, Pelletier G, Savard K (2009) New Staphylinidae (Coleoptera) records with new collection data from New Brunswick, Canada. I. Aleocharinae. In: Majka CG, Klimaszewski J (Eds) Biodiversity, biosystematics, and ecology of Canadian Coleoptera II. ZooKeys 22: 171-248. doi: 10.3897/zookeys.22.152 